$$
\text { كلية الدراسات الإسلامية الأزهر والعربية }
$$

\title{
بمث بعنوان
}

آية الرينة من سورة آل عمران (آية رقم عا (1) دراسة تحليلية هوضوعية

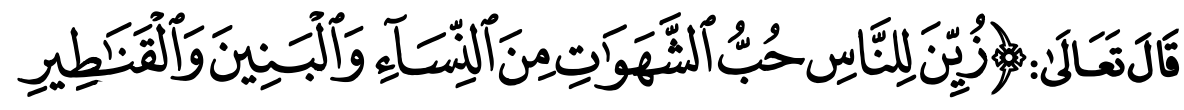

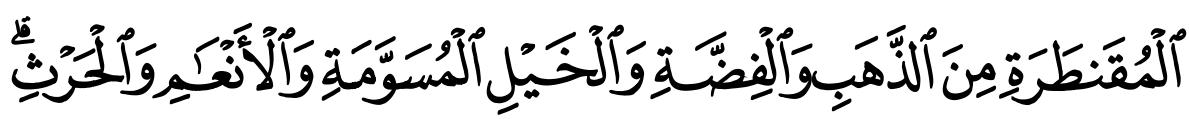

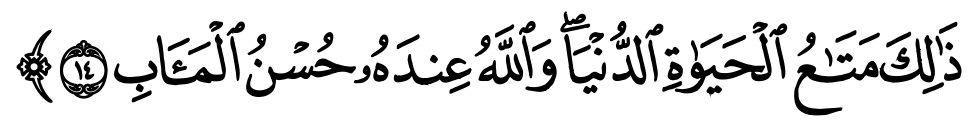

\section{للباحثة}

أمورة السيد إبراهيم السيد

الملدرس بقسم التفسير وعلوم القرآن

بكلية الدراسات الإسلامية والعربية للبنات بالمنصورة 


$$
\text { التوصيف الأكاديمي: مدرس }
$$

عنوان البحث : آية الزينة من سورة آل عمران (آية رقم ع ()

دراسة تحليلية موضوعية

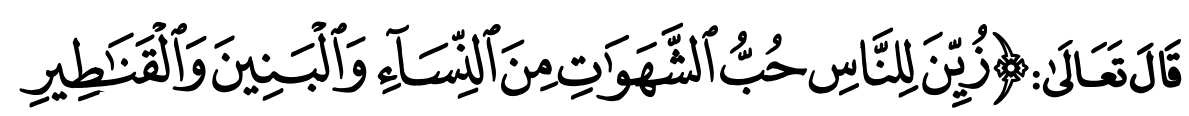

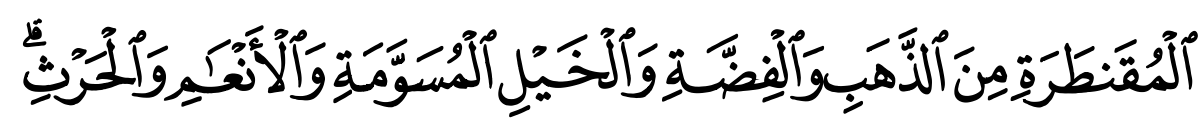

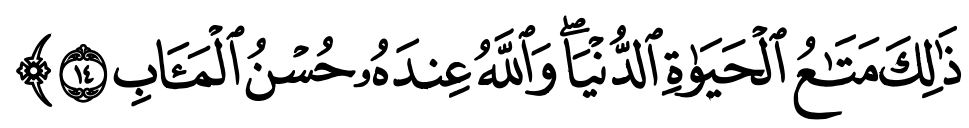

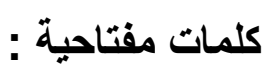

الزينة ، الثهوة :النساء ، البنين، المال ، الذهب، الفضة، الخيل ، الأنعام ،

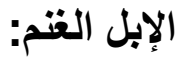

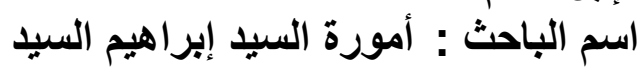
عنوان الباحث : كلية الدراسات الإسلامية و العربية للبنات بالمنصورة ، جامعة الأزهر 


\section{|li|l}

ذكر الله - عزوجل- في هذه الآية أهم المشتهيات التي يخبها الناس، وقتفو

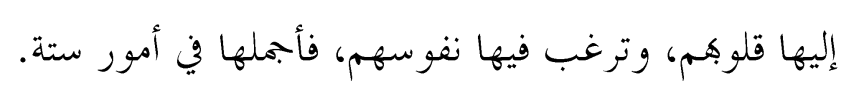

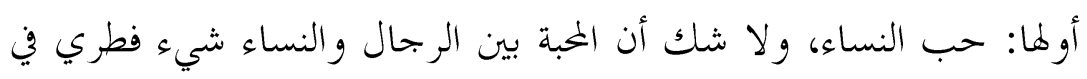

$$
\text { الطبيعة الإنسانية، }
$$

حيث أن بعض الرجال قد يستهين بكل شيء في سبيل الوصول إلى المرأة التي يهواها

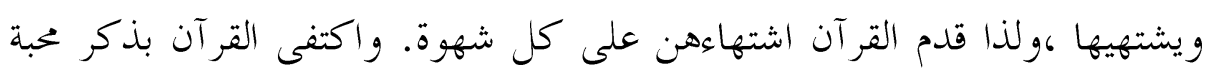

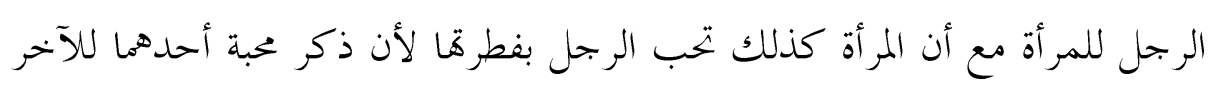

$$
\text { يغني عن ذكر الطرفين معا. }
$$

ثانيها: حب البنين، وقد ذكر حب البنين بعد حب النساء لأن البنين ثمرة

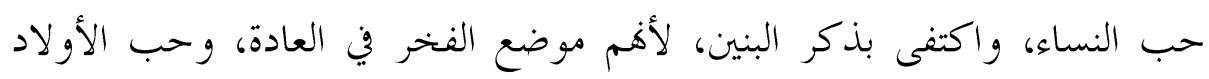
طبيعة في النفس البشرية.

و الإنسان في سبيل حبه لأولاده يضحى براحته، وقد يجمع المال من أجلهم

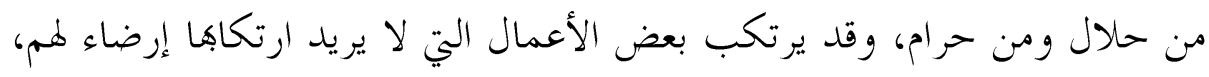

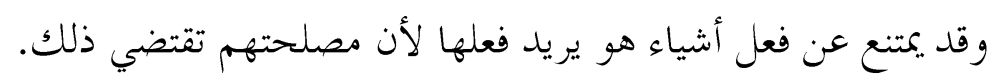

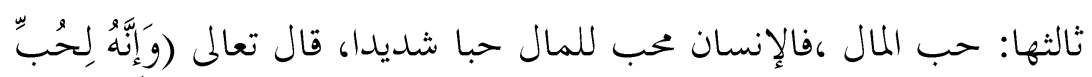

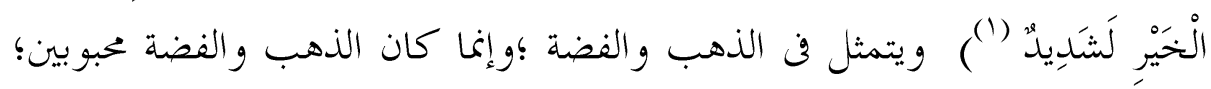

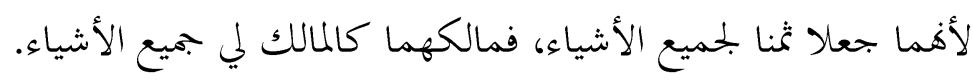

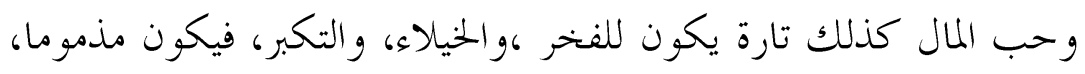
وتارة يكون للنفقة في وجوه البر فيكون محمودا. 


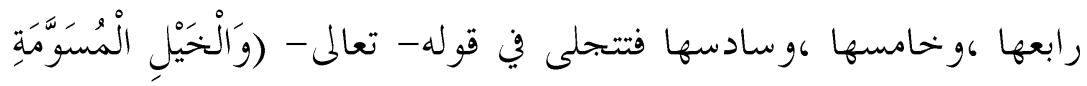

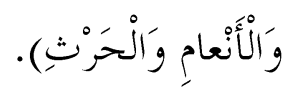

والحيل كانت وما زالت زينة محبة مرغوبة، مهما تفنن البشر في اختراع

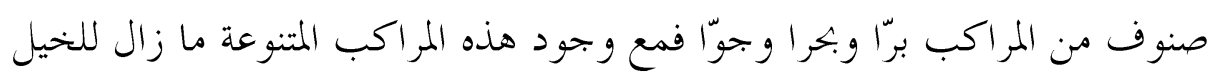

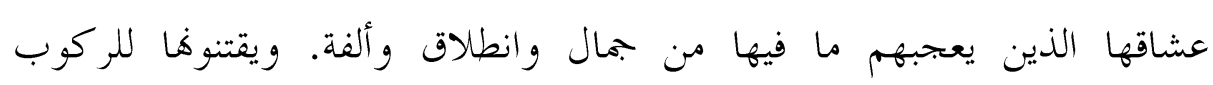
و المسابقات..

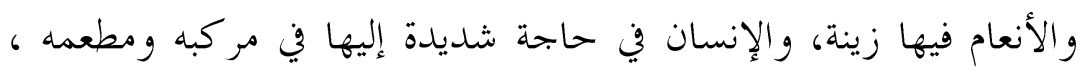

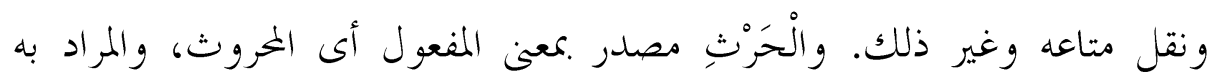

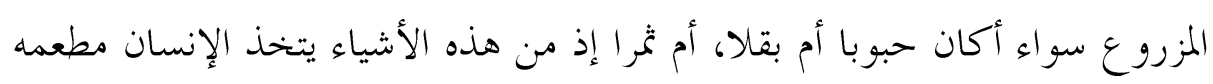
وملبسه وأدوات زينته.

تلك هي أهم المشتهيات في هذه الحياة إلى نفس الإنسان قد جمعها القرآن

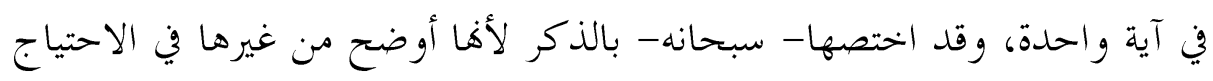

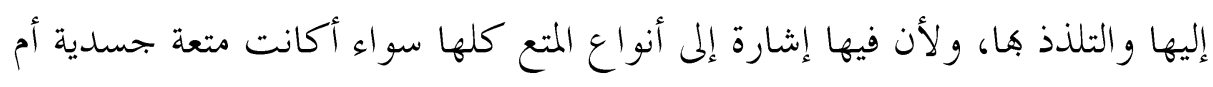

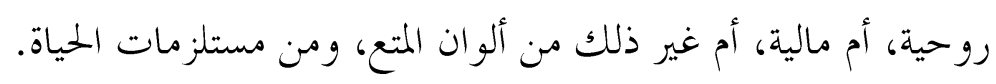

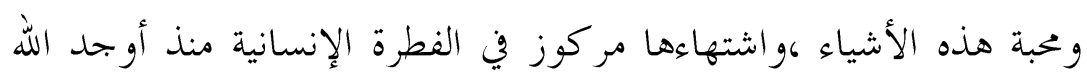

الإنسان في هذه الحياة الدنيا.

وهذه المتشهيات ليست خسيسة في ذاتما، ولا يقصد الإسلام إلى تخسيسها

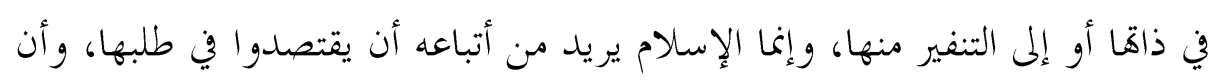

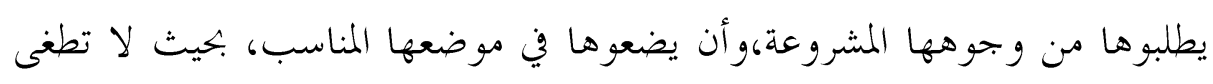

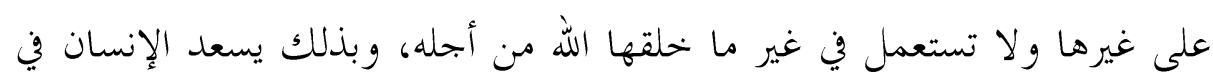
دنياه وآخرته . 


\section{Summary}

Allah Almighty mentioned - in this verse.

The first is love for women، and there is no doubt that love is between men and women

Where some men may be impossible? And the Qur'an only mentioned it.

The second: Boys 'love، boys' love، love، love، or love.

A person in the way of his love for his children sacrifices his comfort، and he may collect money for them from permissible and forbidden things، and he may commit some acts that he does not want to commit to satisfy them، and he may refrain from doing things he wants to do because their interest requires it.

Thirdly: love of money، for a person loves money with great love، the Almighty said (and it is for the love of good to be strong.

And it is represented in gold and silver; rather، gold and silver were loved، because they made a price for all things، for their owner is like the owner for all things.

and ، shame،And the love of money is also sometimes for pride and sometimes for alimony in ، so it is reprehensible،arrogance . then it will be commendable the faces of righteousness

And love of money as well، can it be for necrosis، existence، and arrogance، so it is reprehensible?

Fourth، the fifth، and the sixth، and it is manifested in the Almighty said: (And the horses are bargained، and the cattle and the tillage).

what about you? Are you here? And own it for rides and competitions. 
And cattle have a decoration، and a person. And the tillage is a source of the meaning of the effect، meaning the plow

These are the most important cravings in this life to the soul of a person that the Qur'an has gathered in one verse، and the Almighty has dedicated it to mentioning because it is clearer than others in the need for and pleasure in it and because it contains a reference to all kinds of pleasures، whether it is physical، spiritual، or financial pleasure. Or other colors of pleasures، and a necessity of life.

The love of these things, and their craving is concentrated in human instinct since God created man in this worldly life.

These appetizers are not despicable in themselves، and Islam does not intend to be despised by itself or to be alienated from them، but Islam wants its followers to economize in its request، to request it from its legitimate faces، and to put it in its proper position، so that it does not overwhelm others and is not used in anything other than What God created for him، and in this way man is happy in this world and its end. 


$$
\text { بسم الله الرحمن الرحيم }
$$

الحمد لله رافع منازل المتمسكين بالذكر المبين، وهادي المؤمنين المتقين،

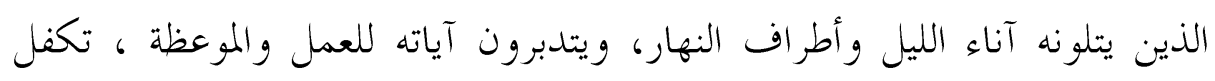
سبحانه بحفظه ، فنحن نقرؤه اليوم كما نزل به الروح الأمين على قلب سيدنا محمد ولند صلى الله عليه و سلم.

والصالاة والسلام على من أرسله الله تعالى رحمة للعالمين، وسراجا منيرا للمخبتين، وعلى آله الطهر الميامين، وصحابته أجمعين. أما بعد:

فقد أرسل المولى سبحانه رسوله بالهدى ودين الحق، وأنزل عليه القرآن

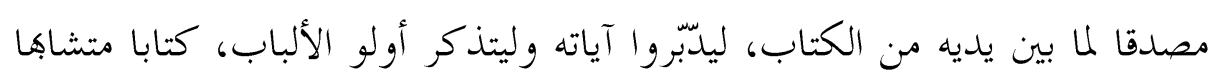
مثاني تقشعر منه جلود الذين يخشون ربهم، فهو المعجزة الخالدة الذي فاق كل بيان، وأخرس كل لسان، وأهر أهل الفصاحة من قحطان وعدنان، بل تحدّى الجلن

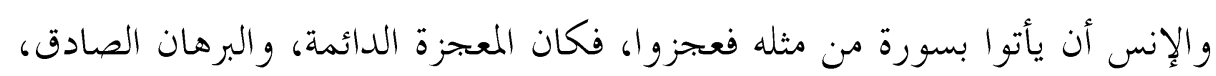
على ما أتى به رسوله من حقائق. من اتبع هداه ... فقد فاز برضاه، و كانت الجنة مأواه، وأما من خالفه ونه وأباه . . فقد اتخذ إلهه هو اه، لا يزيغ عنه إلا هالك، ولا يجحده إلا مكابر.

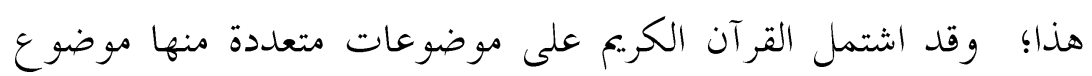
الزينة وهي من أهم موضوعات العصر الحديث خحاصة مع تطور أدوات التجميل

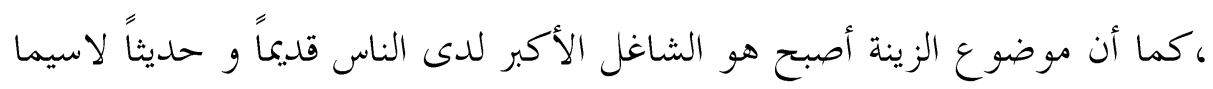

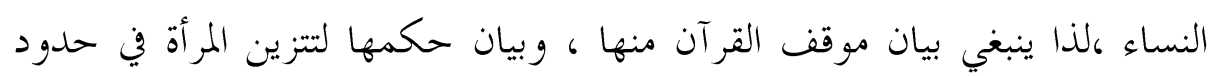

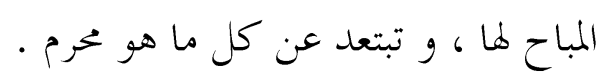


كما أن السعي وراء الشهوات هو المسيطر الأكبر على تصرفات الإنسان ،

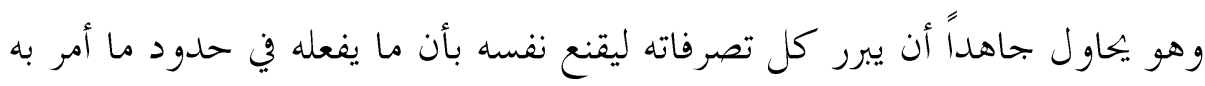

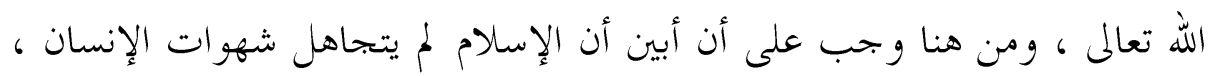
و لم يتنكر ها بل جعل لها متنفساً شرعياً تؤدى من خلاله ، ولو ائو سعى الإنسان

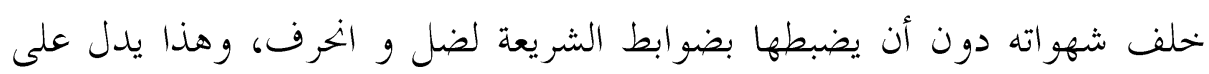
وسطية الدين الإسلامي · مأك

كذلك أباح الإسلام الزينة للرجال و النساء بشروط معينة فهو لم يبح الزينة مطلقا و لم يبح إظهارها أمام كل الناس خاصة زينة النساء ، و لم يحرم الزينة مطلقا .

\section{ومن ثم وقع اختياري لهذا الموضوع:}

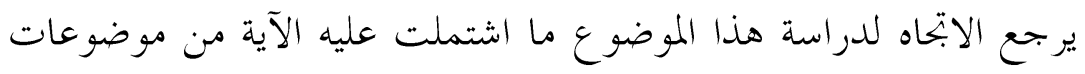
متعددة تدل على إعجاز القرآن الكريم فالآية تحدثت عن الزينة ، و عن الشهوات ، وقد ذكرت الآية ثلاثة أنواع من الشهوات شهوة حب النساء ، وحب البنيين ، و و

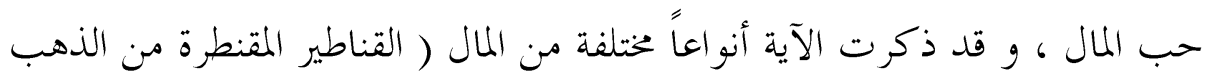

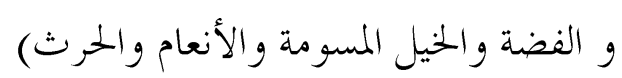

وبينت سبب البدء بشهوة النساء وتحدثت عنها، و أتبعتها بالحديث عن ولن

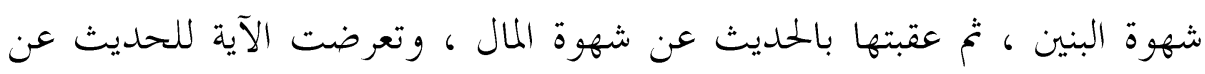

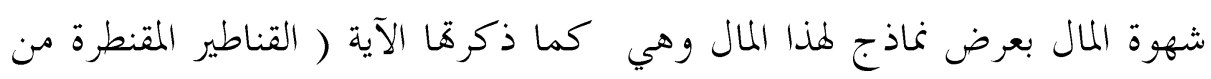

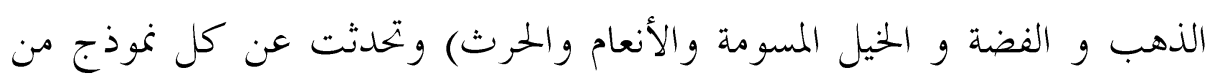

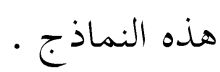

وختمت الحديث .ما ختم الله به الآية بيان بأن هذه شهوات الدنيا الفانية،

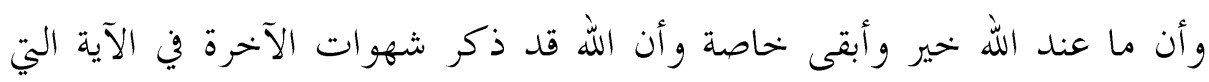

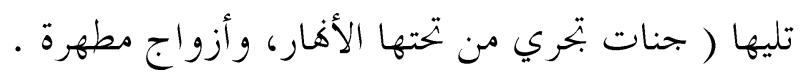


وقد قسمت البحث إلى مقدمة وأربعة مباحث و خاتمة

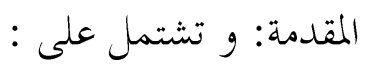

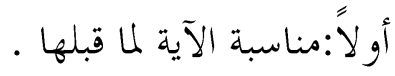

ثانياً:سبب نزول الآية الكريمة.

المبحث الأول : المباحث اللغوية ويشتمل على:

أولاً: معاني المفردات الغريبة.

ثانياً:ما تضمنته الآية الكريمة من صور بلاغية.

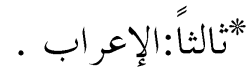

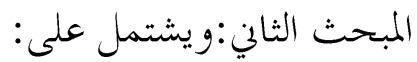

أولاً: القراءات.

ثانياً:المعنى العام للآيةالكريمة ( التفسير الموضوعي).

المبحث الثالث :التفسير التحليلي.

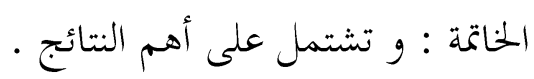

وأتبعت ذلك بالمصادر . مان.

هذا، وما كان من توفيق فمن الله ،وما كان من سهو أو خطأ أو نسيان

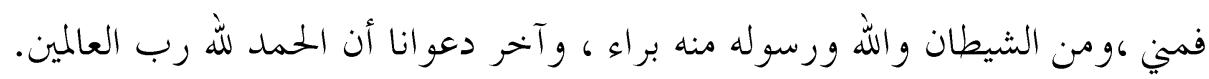




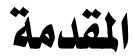

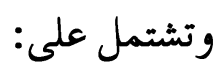

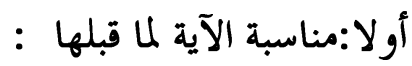

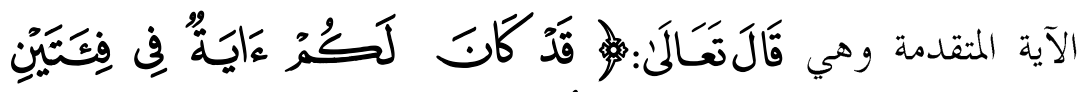

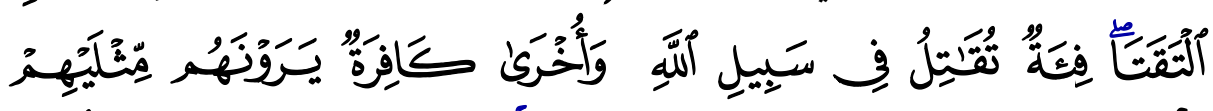

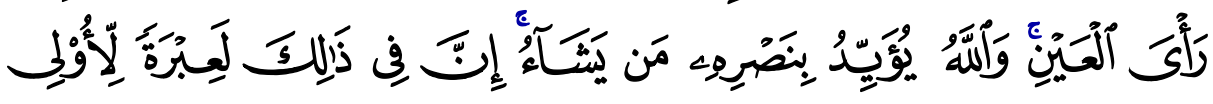

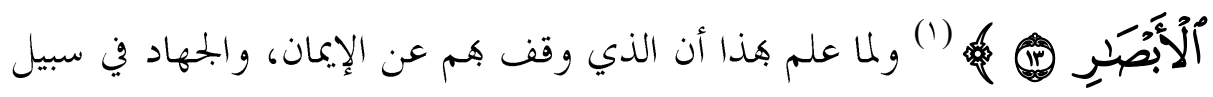

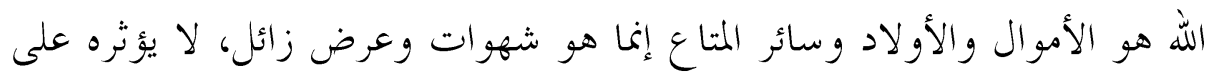

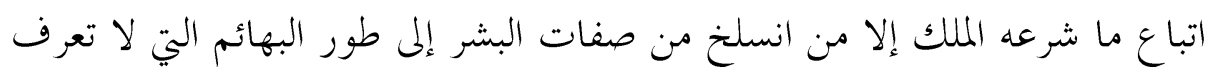

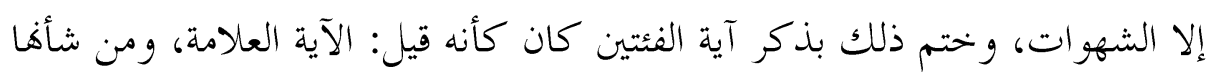

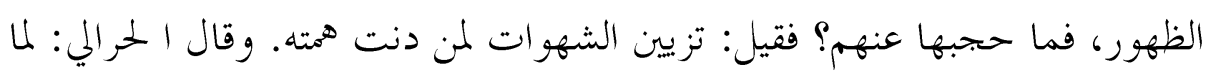

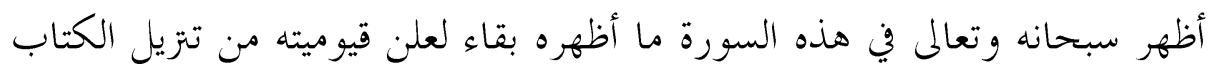

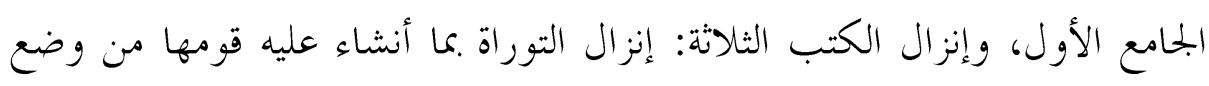

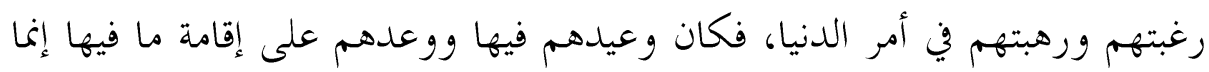

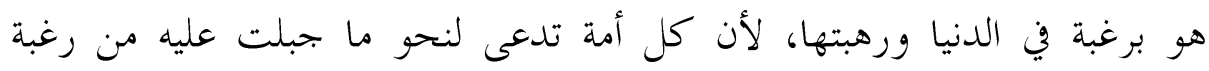

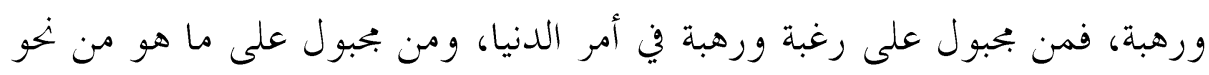

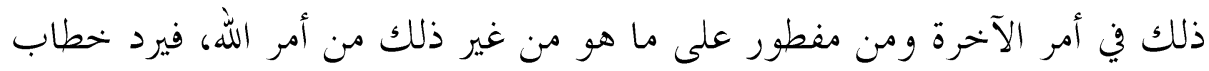

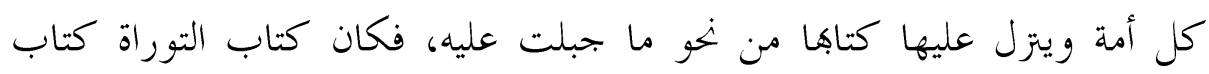

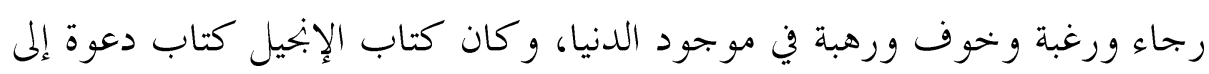

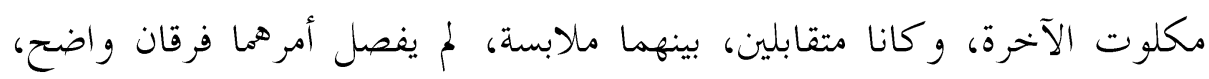

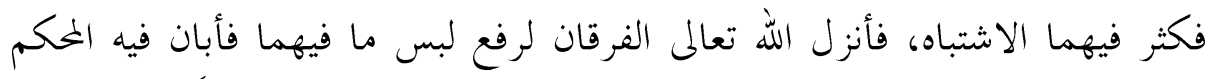

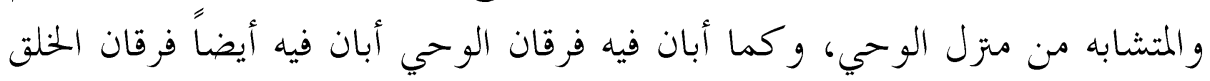


وما اشتبه من أمر الدنيا والآخرة ووام التبس على أهل الدنيا من أمر الخلق بلوائح

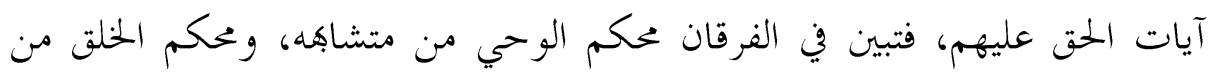

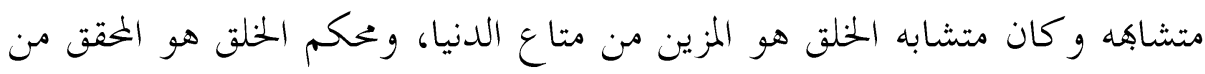

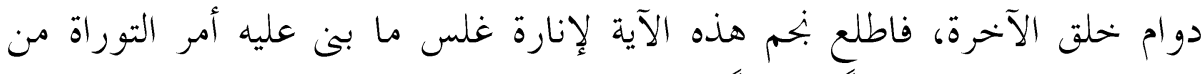

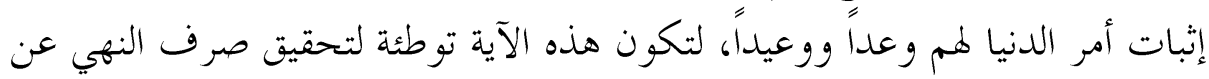

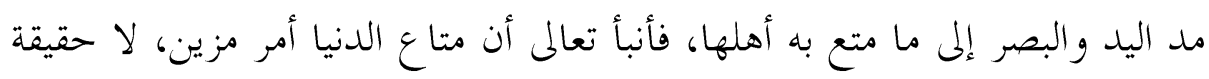

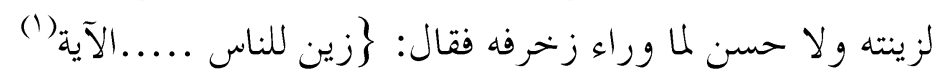

وخلاصة القول أنه بعد أن توعد الله الكافرين بالهزيمة من المؤمنين، وآذهم

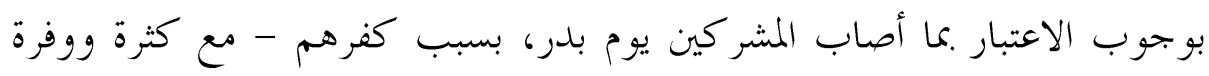

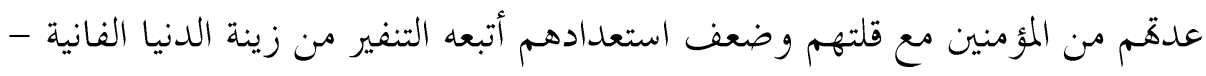

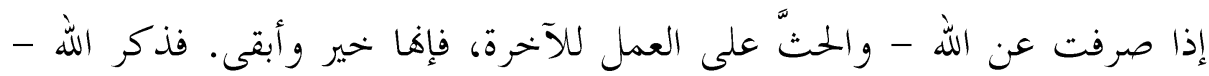

$$
\text { شبانياً:سبب - هذه الآية الكريمة. }
$$

إن وفد بنران لما دخلوا المدينة تزينوا بأحسن زي فتشوقت نفوس رجال النال

$$
\text { من فقر اء المسلمين إليهم فنزلت. }
$$

وقيل(r): أهم دخلواء المطلن إلهم فرلت المسجد العصر وهم في جمال رجال بني الحارث وعليهم

الحبرات(") (")

$$
\begin{aligned}
& \text { نظم الدرر في تناسب الآيات والسور،المؤلف: إبراهيم بن عمر بن حسن الرباط بن علي بن أبي بكـــــا }
\end{aligned}
$$

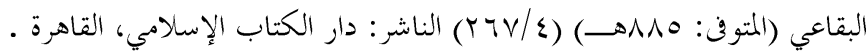

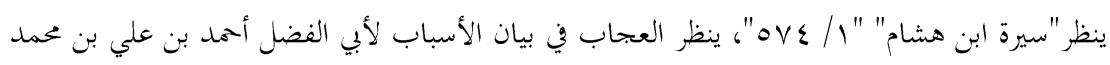

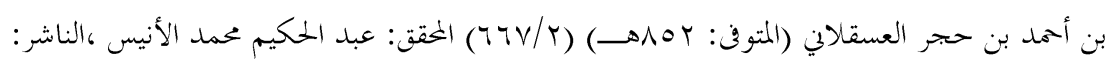

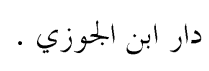

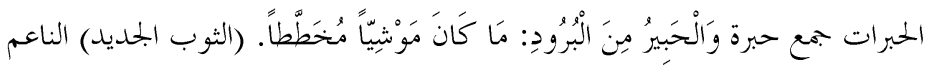


إن هذه القصة كانت بعد الحديبية وقبل الفتح كما صرح به ، وقد ذكرت

بعض الروايات أن صدر سورة آل عمران نزل وتر كها على إطلاقه (1)، وبعضها وهيه

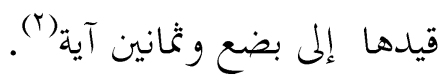

ولا تعارض بين الروايات فيحمل المطلق على المقيد ، و هذا يعايه يعني أن نزول

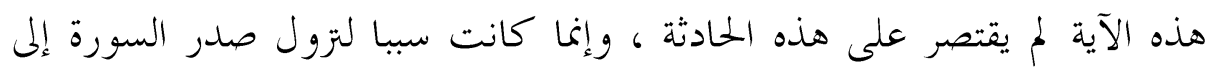
بضع وثمانين آية .

تاج العروس من جواهر القاموس محمّد بن محمّد بن عبد الرزّاق الحسيني، أبو الفيض، الملقّب بمرتضى،

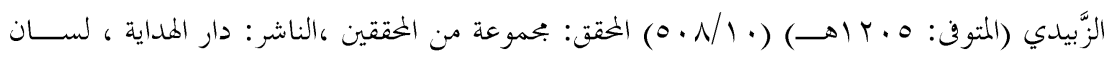

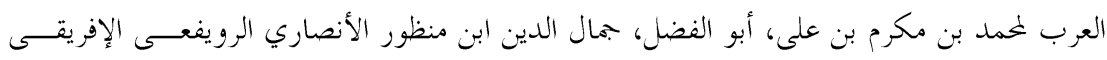

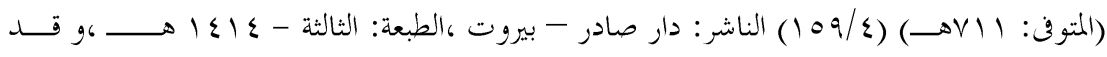

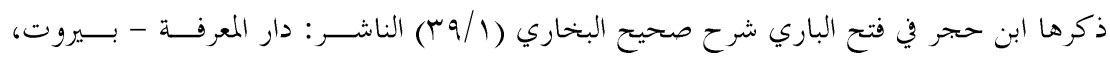

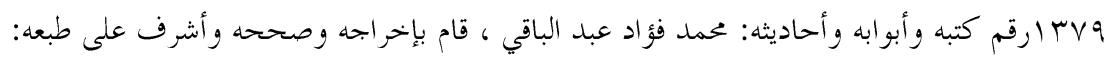

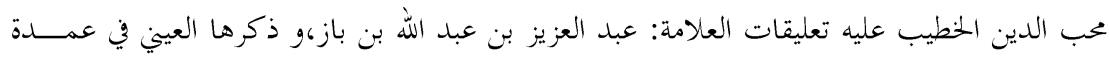

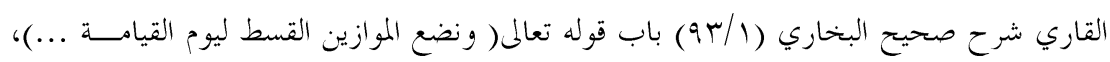

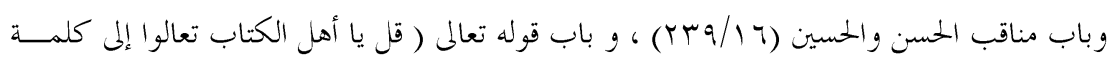

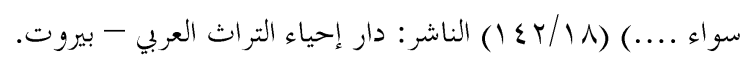

المواهب اللدنية بالمنح الخمدية لأحمد بن محمد بن أبى بكر بن عبد الملك القسطلاني القتيبي المصري، أبو إحياء

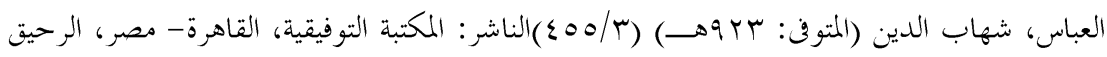

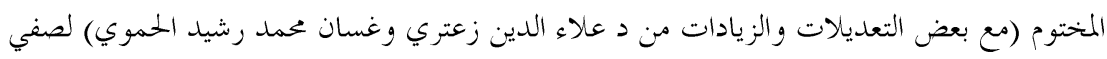

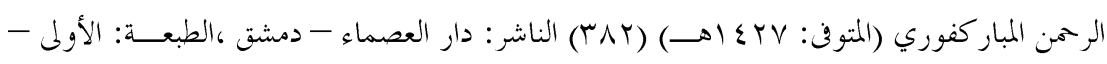

الروض الأنف في شرح السيرة النبوية لأبي القاسم عبد الرحمن بن عبد الله بن أحمد السهيلي (المتـــوفي:

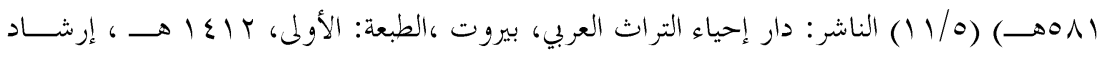

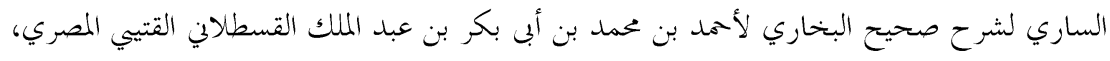

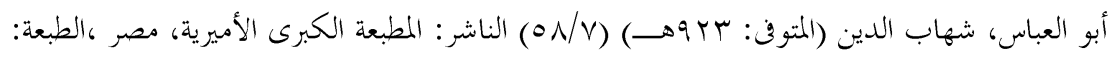

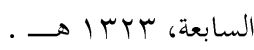




\section{المبحث الأول}

\section{ويشتمل على: \\ أولاً: بيان المفردات الغريبة:}

الزينة: بالكسر، ما يتزين به ،والزين: ضد الشين ،وهي اسم جامع لكل شيء يتزين

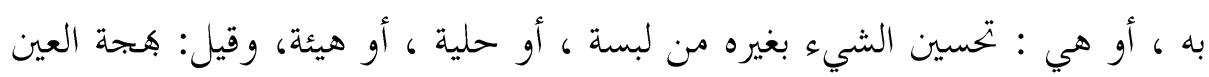
التي لا تخلص إلى باطن المزين. و الزينة: الحقيقية ما لا يشين الإنسان في شيء من أحواله لا في الدنيا ولا في الآخرة،

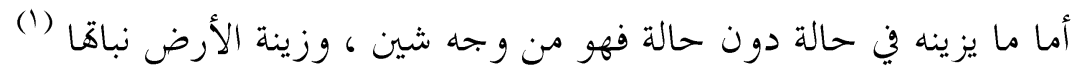

\section{الشهوة:}

أصل الشَّهْوَة: نزوع النّفس إلى ما تريده، وذلك في الدّنيا ضربان: صادقة،

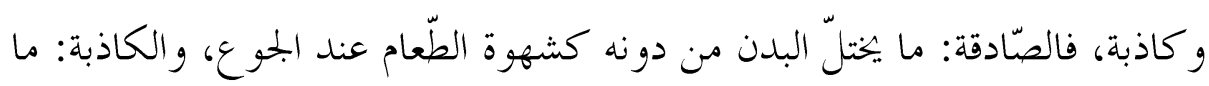

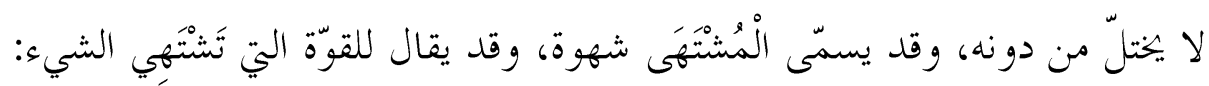

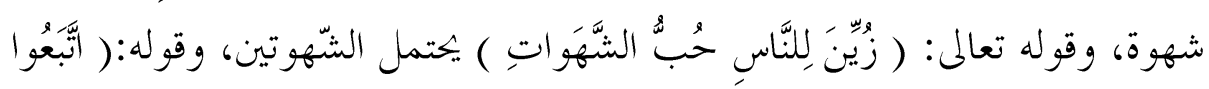

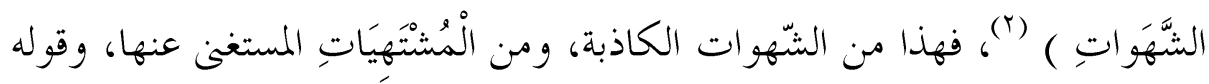

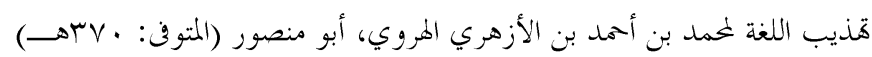

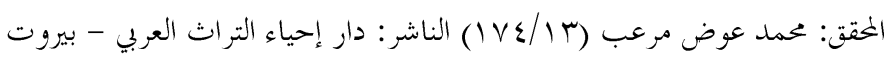

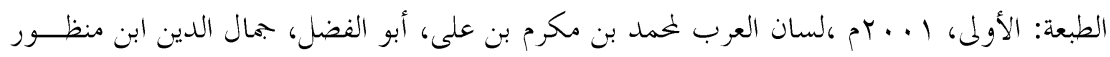

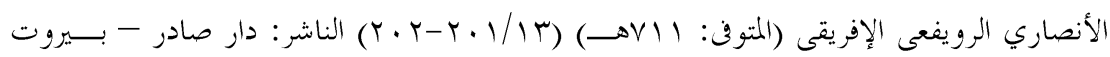

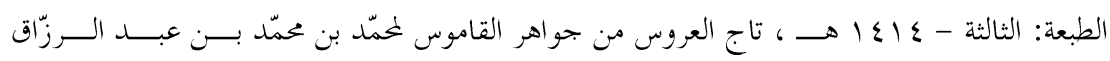

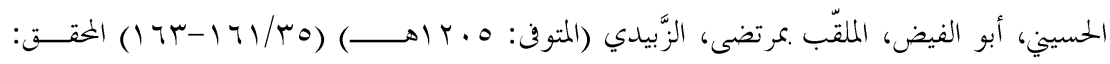




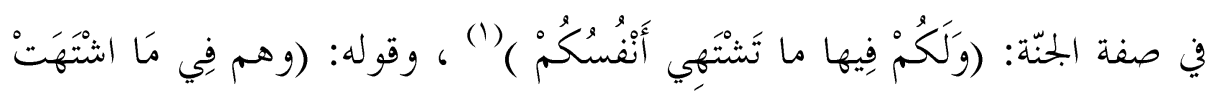

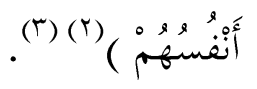

القنطار: معيار يزن أربعة آلاف دينار (مثقال) أي نهو

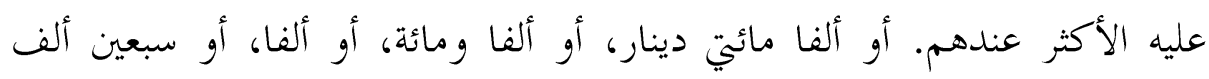

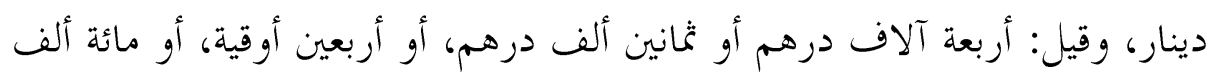

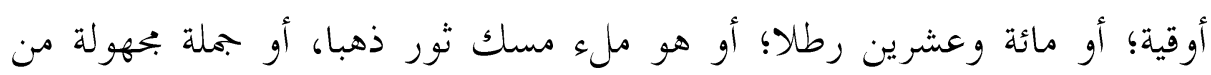

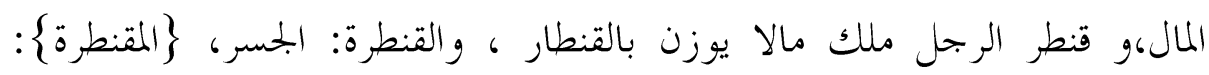

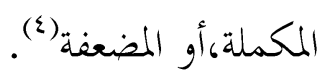

$$
\text { فصلت: الأنبياء/ T-1 }
$$

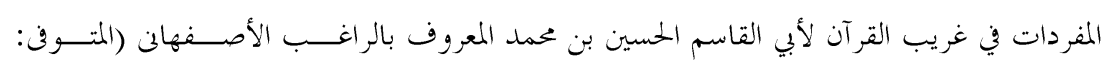

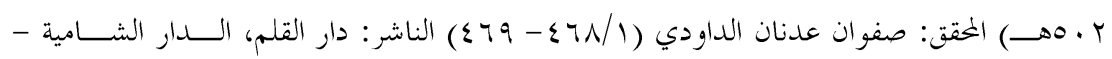

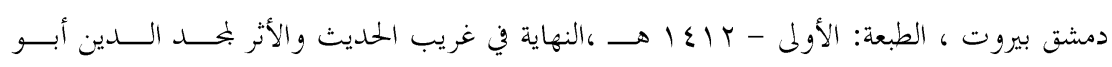

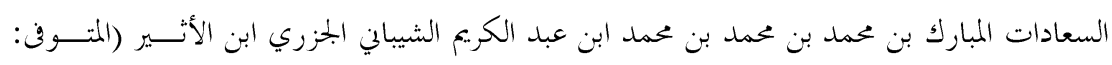

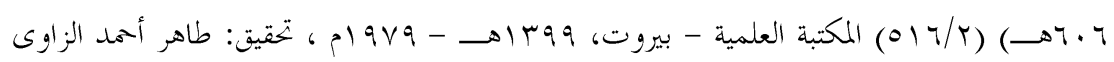

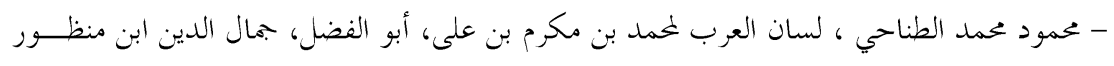

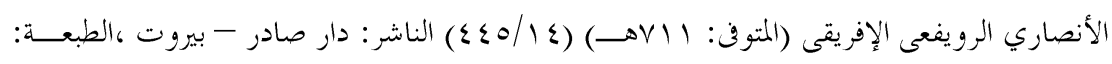

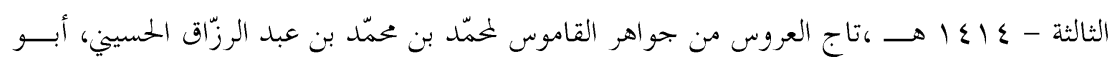

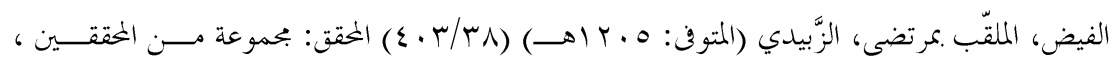

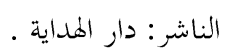

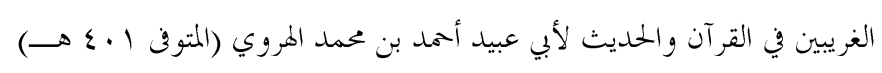

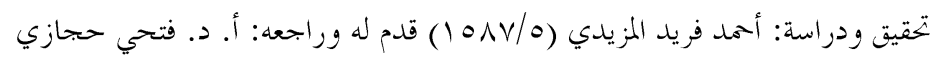

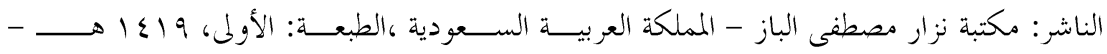

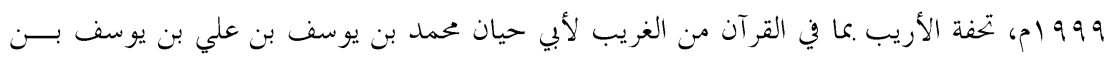

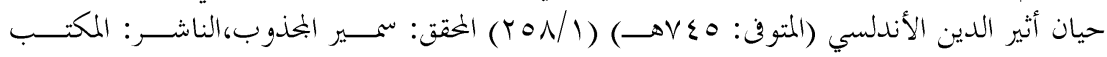

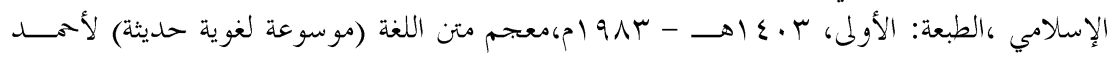

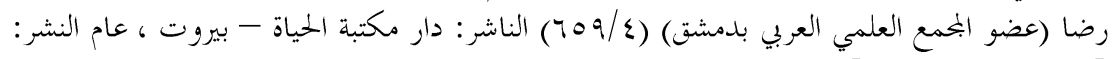

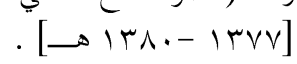


و المر اد منها الكثرة الكثيرة من المال ، وليس مقدار، أو كمية معينة من المال .

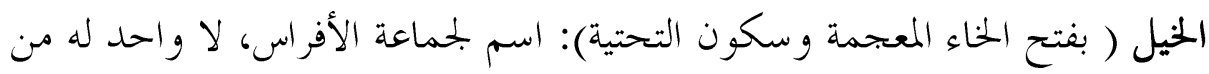

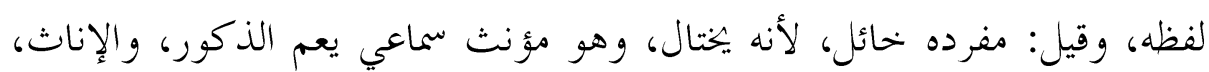

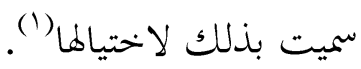

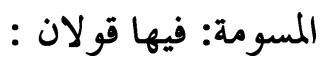

أحدهما: أفا الخيل المرسلة في مراعيها وتكون للنسل ،وتسام أي ترعى ولا تعلف، وقد سامت تسوم إذا رعت وأستها إذا رعيتها.

\section{الثاني : المسومة أي المعلمة بعلامة تعرف هما، والسومة: العلامة(؟).}

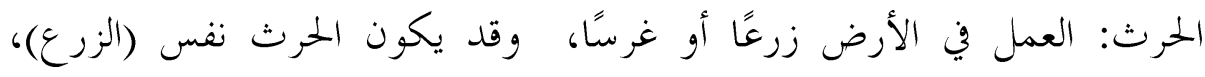
والحرث: قذفك الحب في الأرض للازدراع، والحراث: الزراع، و من الجماز: الحرث

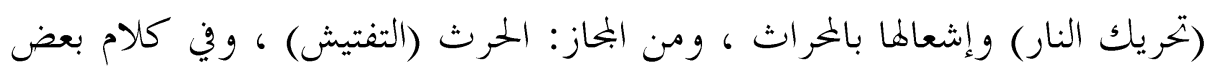
الأئمة: الحرث: تفتيش الكتاب وتدبره. ويطلق على التفقه ، يقال: حرث، إذا تفقه، ويقال: احرث القرآن، أي ادرسه،

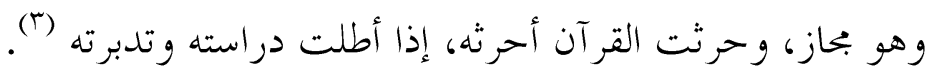

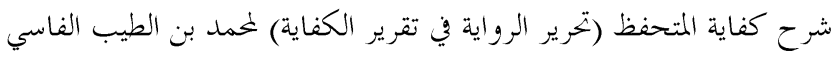

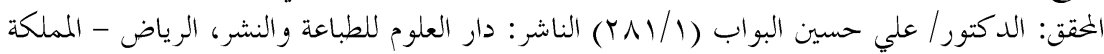

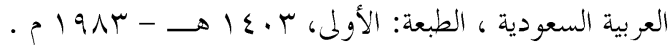

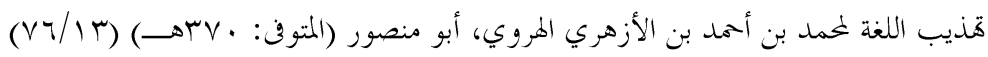

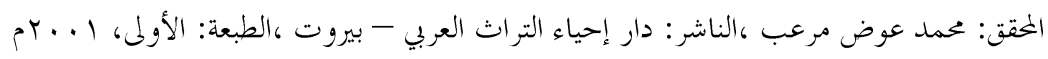

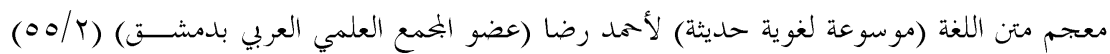

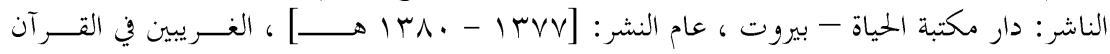

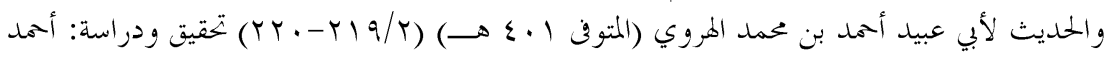

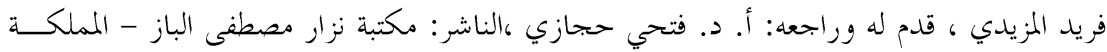

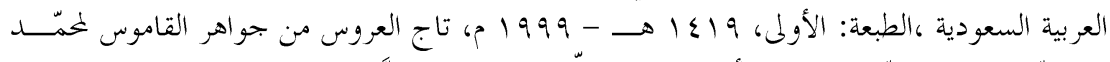

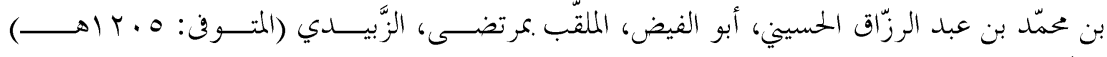

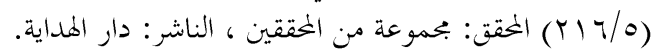


المئاب : آب إلى الشيء: رجع، فهو آيب وآئب، وقيل لا يكون الإياب إلا إلا

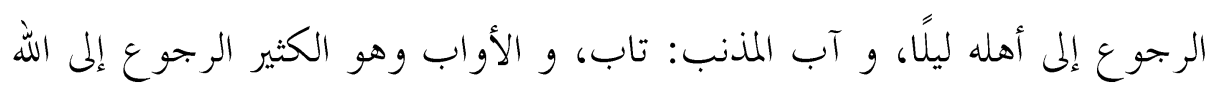

بالتوبة (1)

\section{ثانياً:البلاغة :}

1- في الآية الكريمة فن مراعاة النظير: وهو أن يجمع الشاعر أو الناثر بين أمر وما

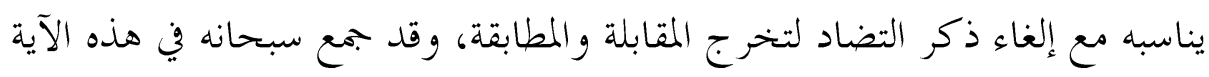

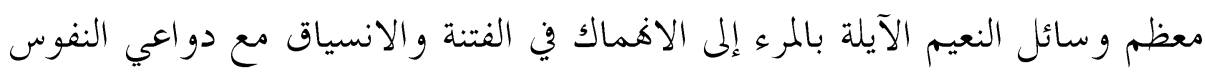

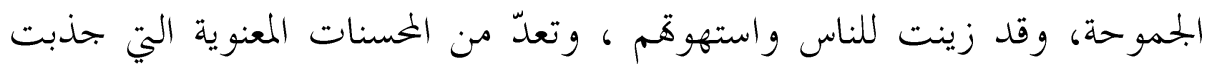

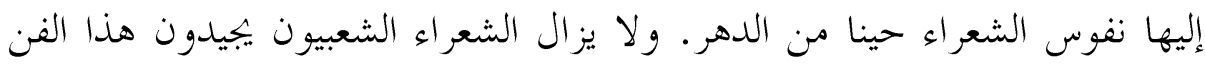
وأمثاله ويتخذونه وسيلة لمعاجزة أقر اهم من الشعراء. (r).

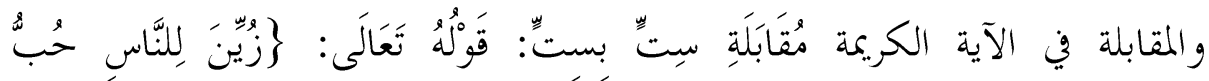

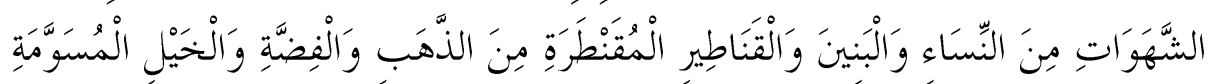

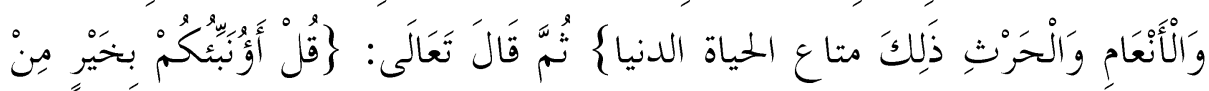

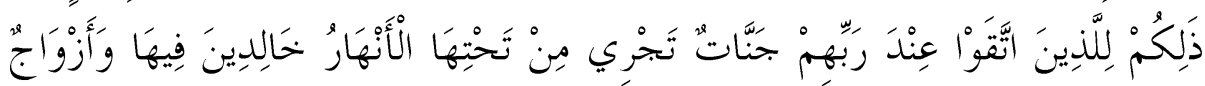

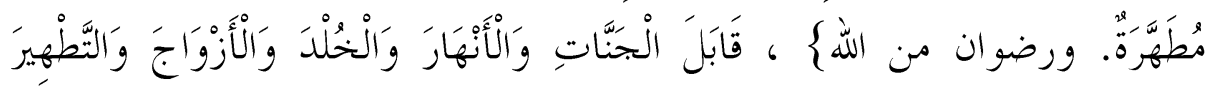

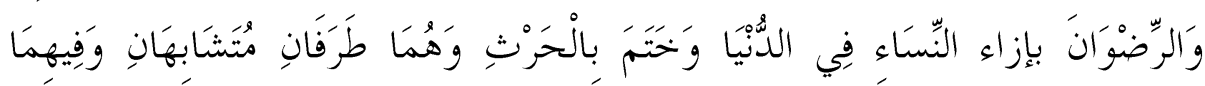

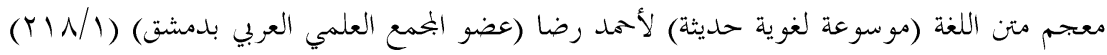

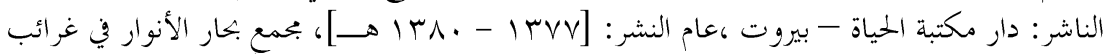

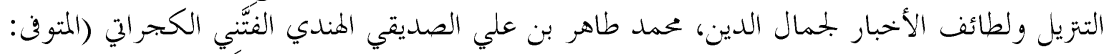

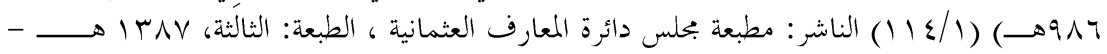

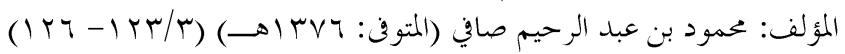

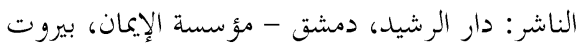

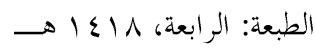




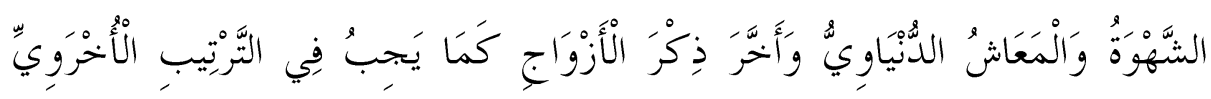

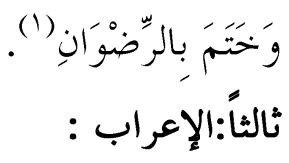

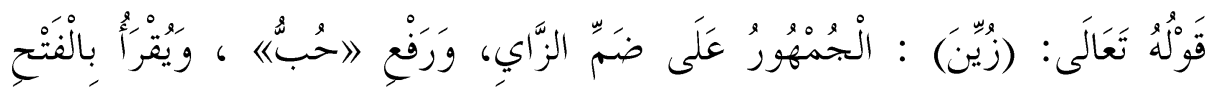

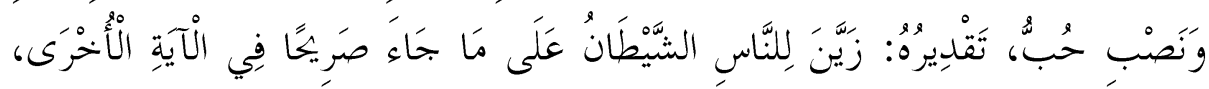

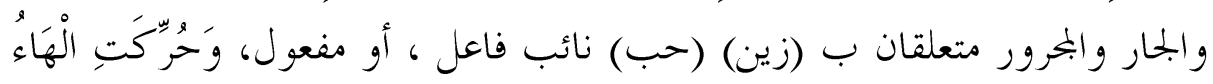

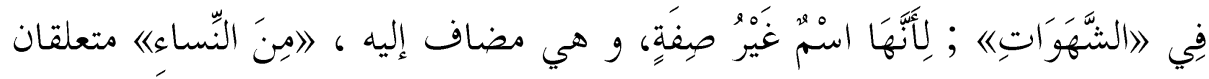

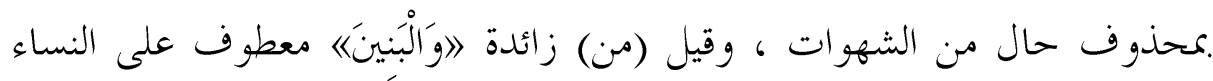

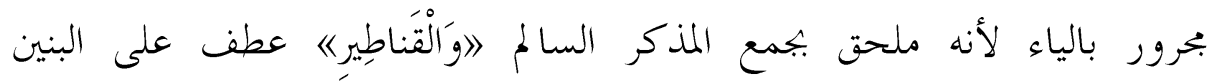

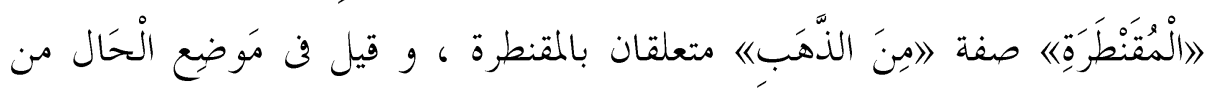

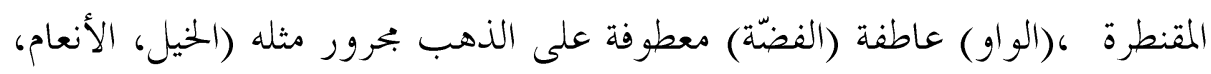

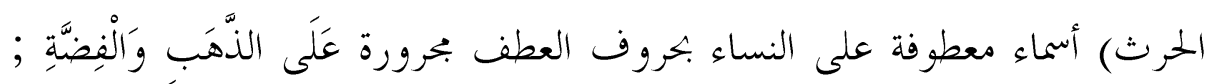

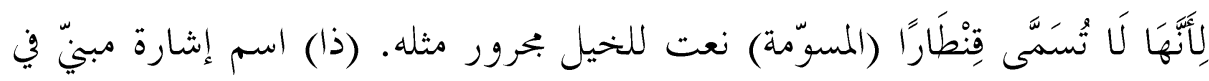

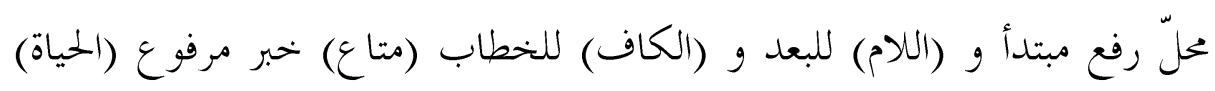

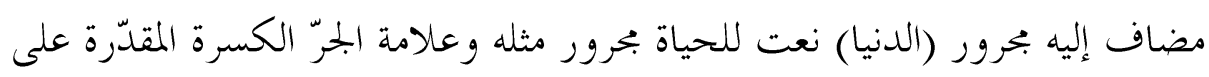

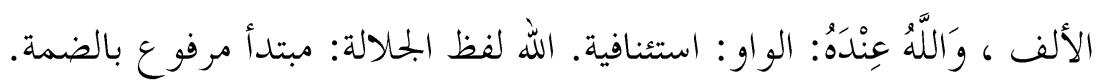
عنده: ظرف مكان منصوب على الظرفية بالفتحة وهو مضاف.

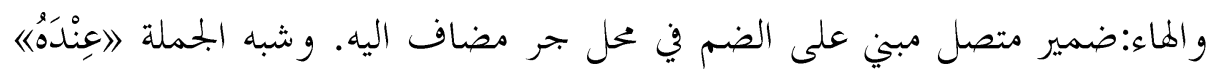
في محل رفع خبر مقدم.

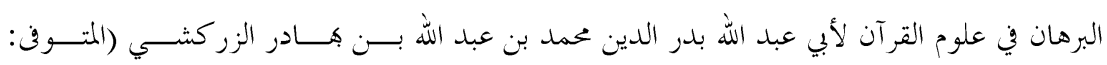

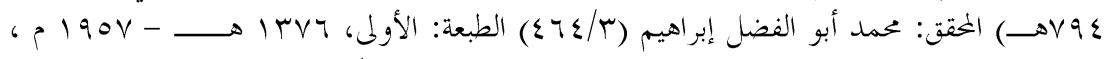

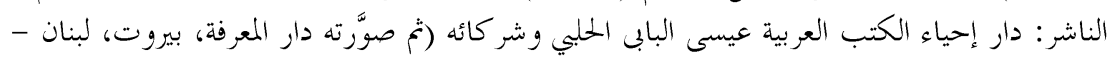

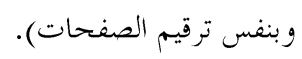


• حُسْنُ الْمَآب: حسن: مبتدأ مؤخر مرفوع بالضمة. المآب: مضاف إليه مجرور

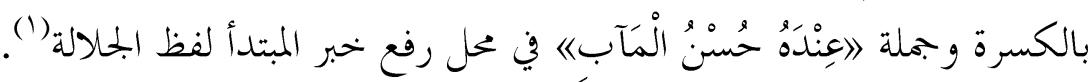

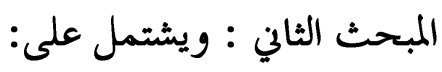
أولاً:القراءات:

قرأ أبو عمرو الداني بإدغام النون في اللام والراء إذا تحرّك ما قبلها لا غير، في اللام

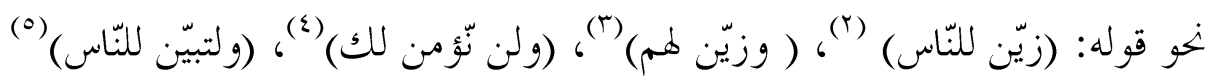
وما أشبهه، إلا فِي قَوله $\}$

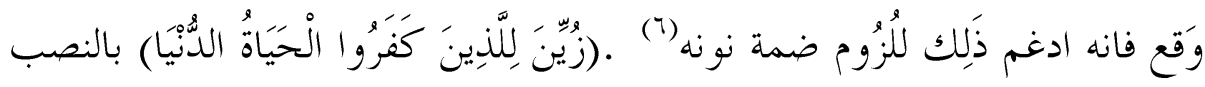

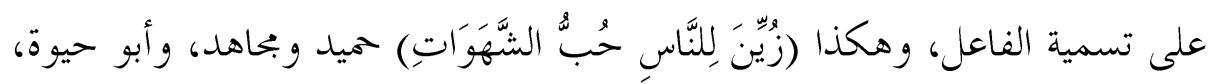

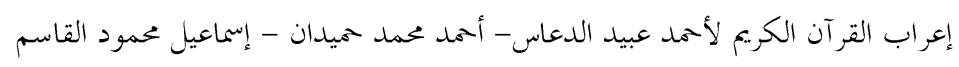

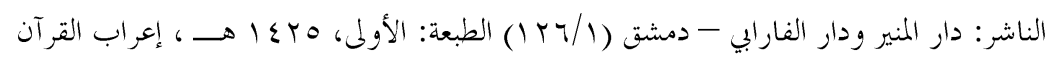

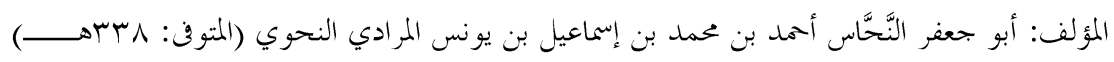

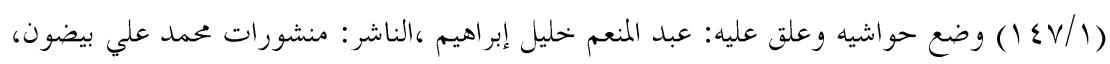

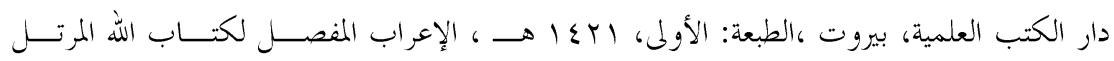

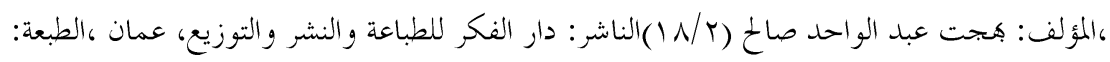

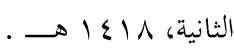

$$
\text { الل الألفمران: عال البقرة: }
$$

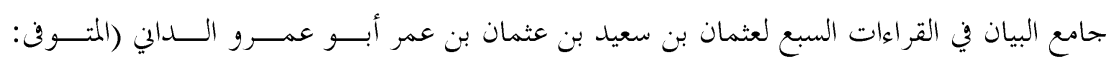

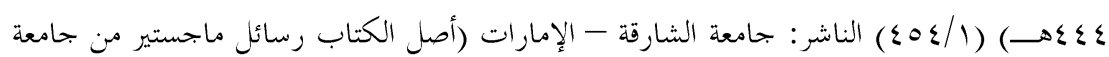

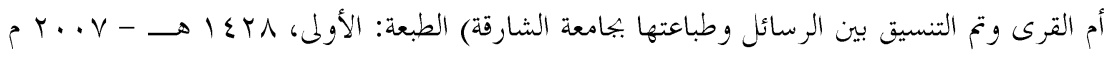

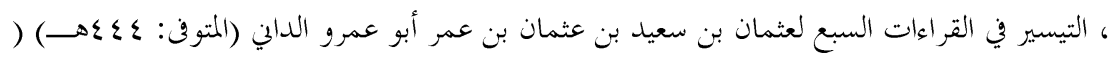

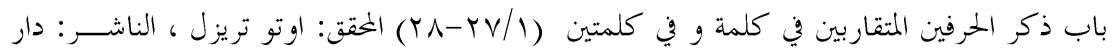

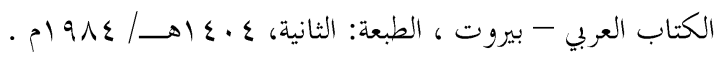




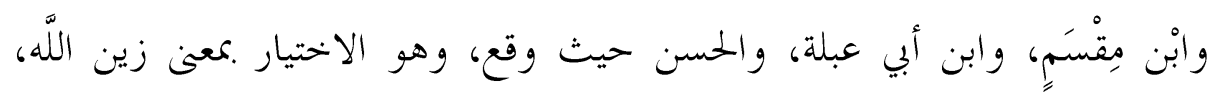

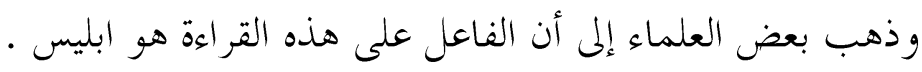

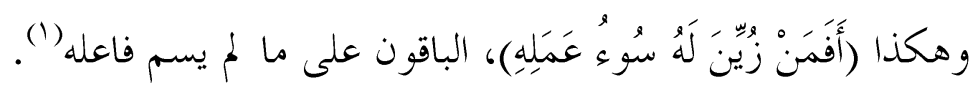

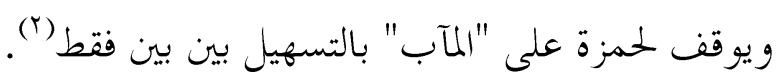

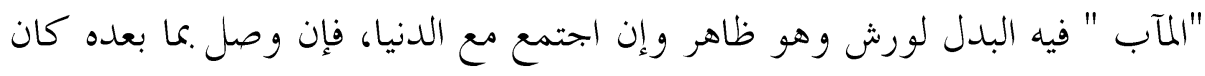

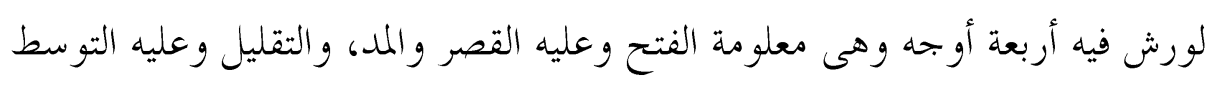

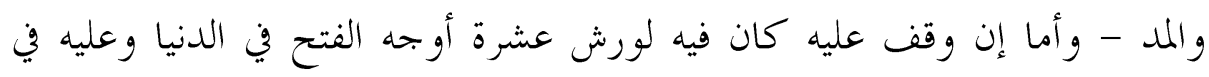

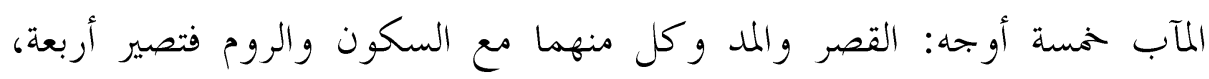

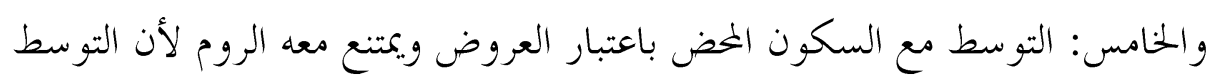
إنما جاز للوقف فقط.

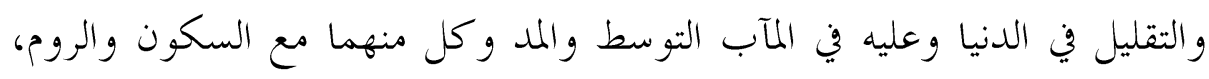

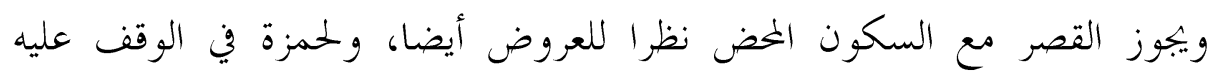

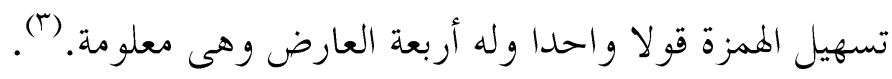

الكامل في القراءات والأربعين الزائدة عليها ليو سف بن علي بن جبارة بن محمد بن عقيل بن سواده أبو

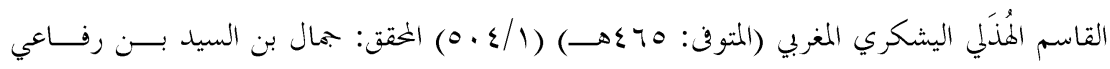

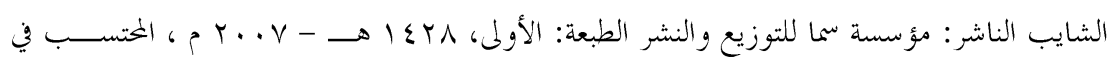

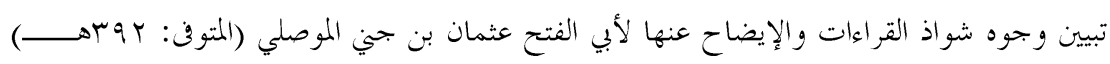
(100/1)

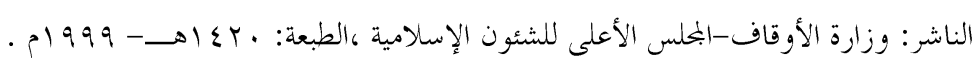

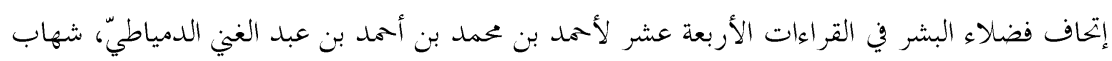

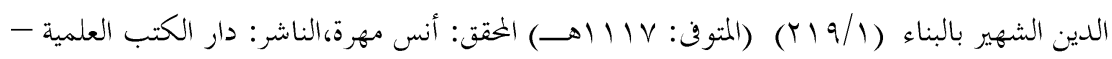

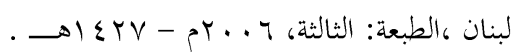

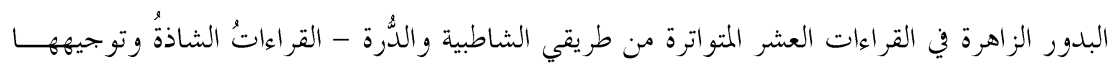

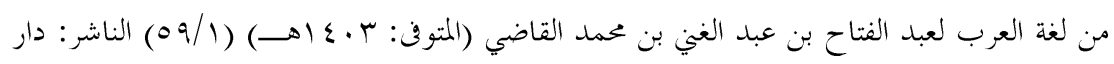

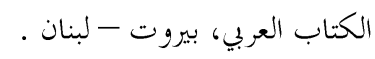




\section{ثانياً: التفسير الموضوعي للآية الكريمة :}

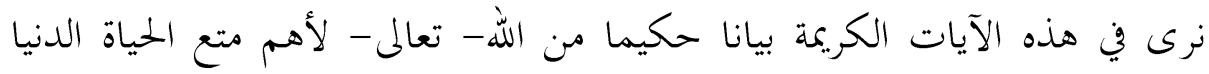

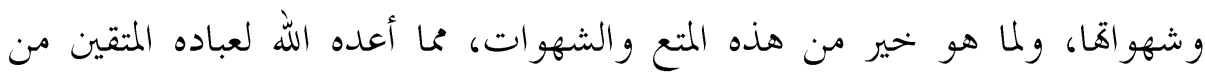

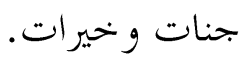
وقوله زيُِّنَ من التزيين وهو تصيير الشيء زينا أى حسنا. والزينة هي ما في الشيء من الخاسن التي ترغب الناظر ين في اقتنائه.

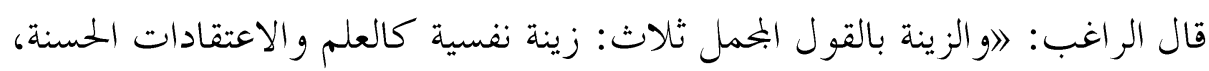

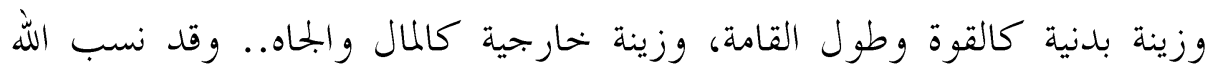

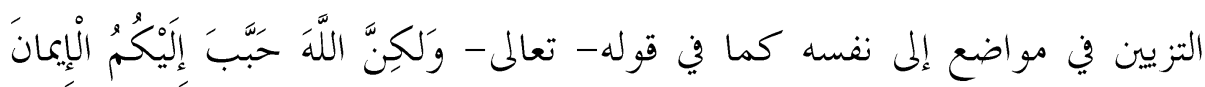

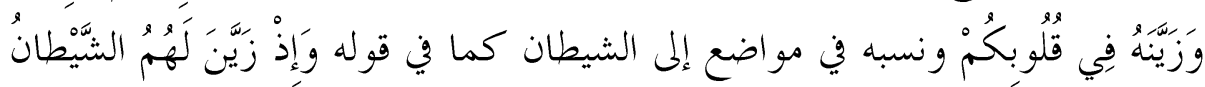

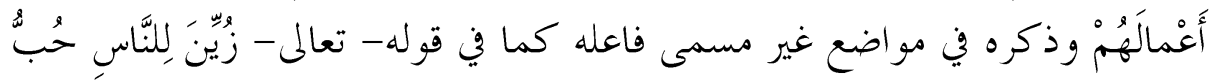

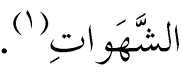

و الشهوات جمع شهوة، وهي ثوران النفس وميلها نحو الشيء المشتهى. والمراد كها

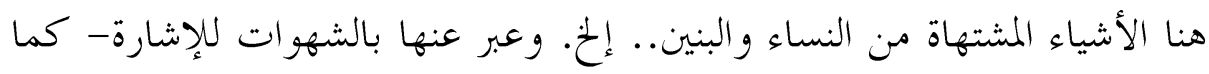

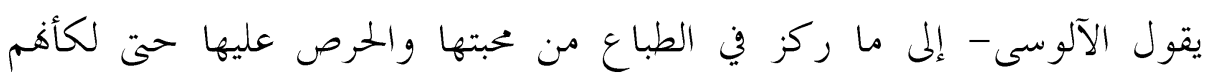

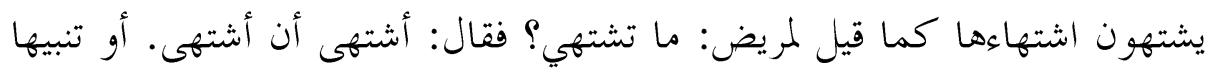

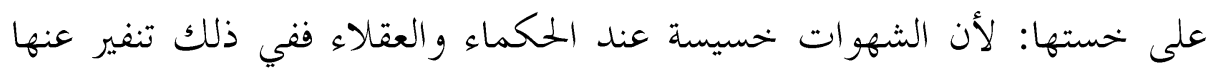

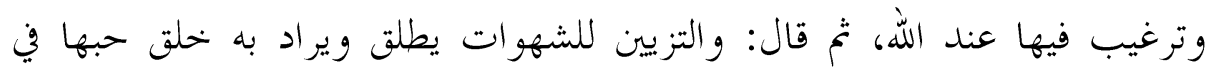

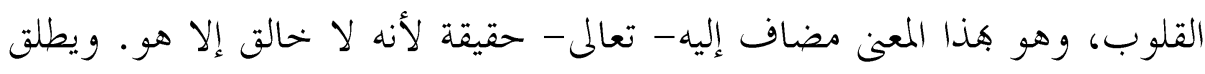

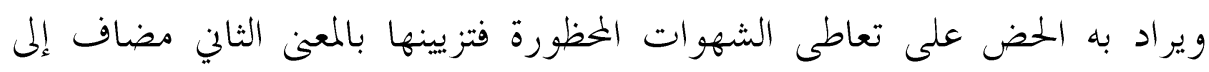

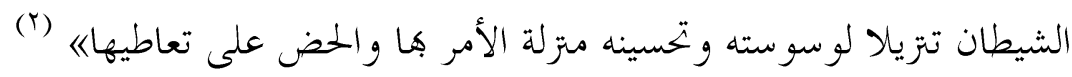

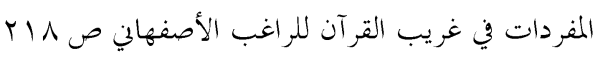

$$
\begin{aligned}
& \text { تفسير الآلوسى (r/ 9/9) بتلخيص }
\end{aligned}
$$

$$
1 \mu \cdot \Lambda
$$


تم بين- سبحانه- أهم المشتهيات التي يحبها الناس، وتّفو إليها قلوهمم، وترغب فيها

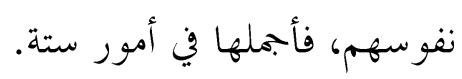

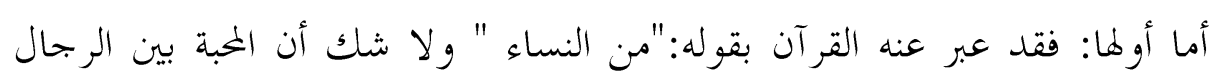

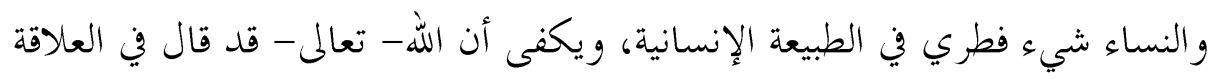

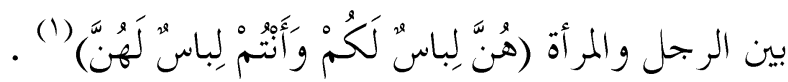

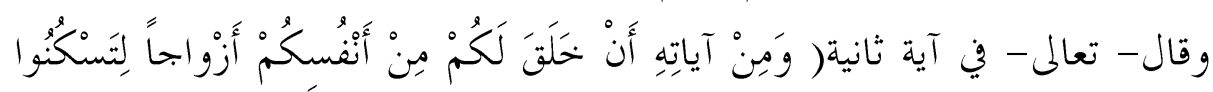

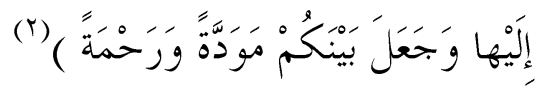
وإن بعض الرجال قد يستهين بكل شيء في سبيل الوصول إلى المرأة التي يهواها

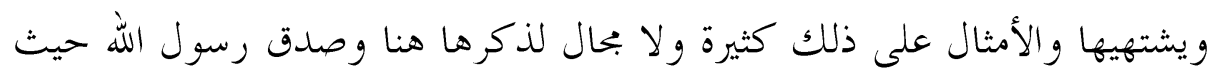

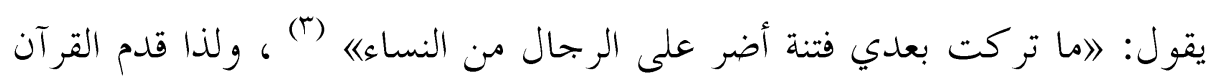

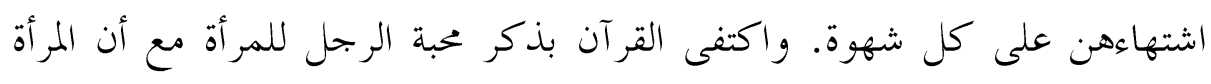

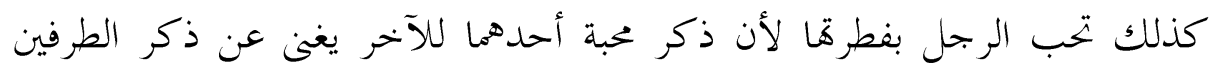

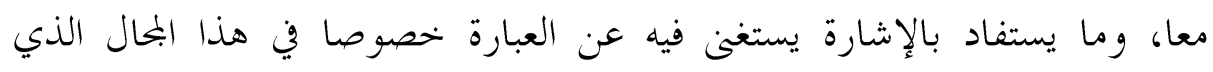

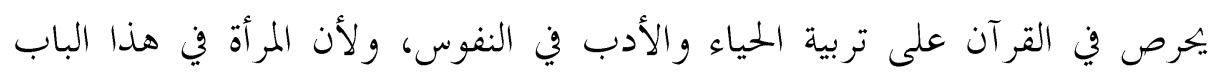

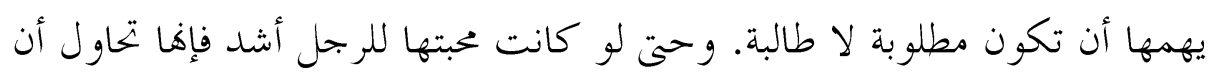
تثير فيه ما يمعله هو الذي يطلبها لا هي التي تطلبه.

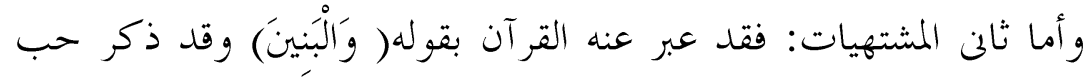

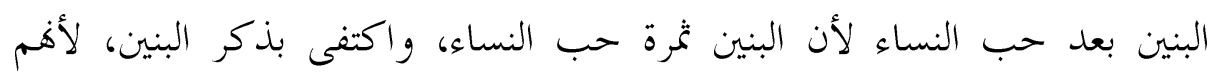

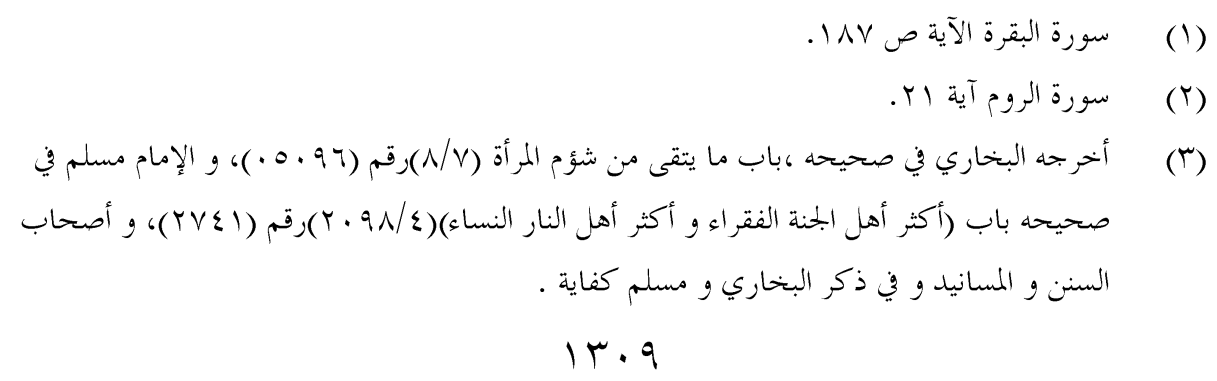


موضع الفخر في العادة وحب الأولاد طبيعة في النفس البشرية فهم ثمرات القلوب،

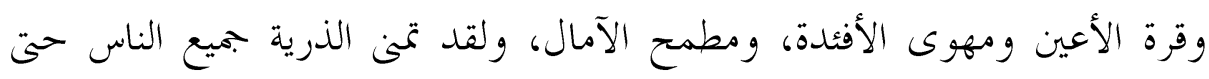

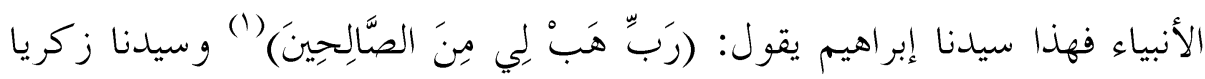

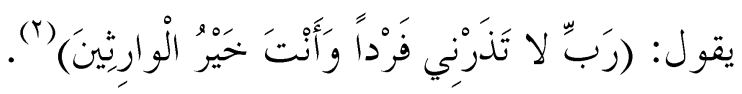
والإنسان في سبيل حبه لأولاده يضحى براحته، وقد يجمع المال من أجلهم من

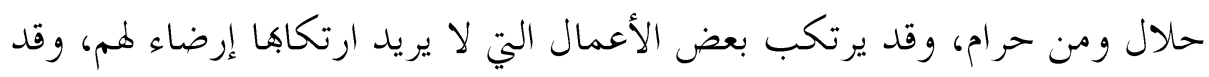

يمتنع عن فعل أشياء هو يريد فعلها لأن مصلحتهم تقتضي ذلك. ونك.

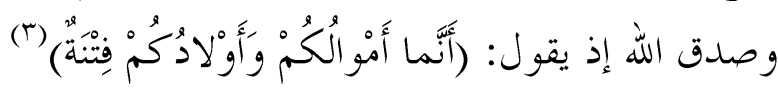
والأبناء يجعلون آباءهم يجبنون خوفا من الموت لئلا يصيب أبناءهم اليتم وآلامه، ويجعلوهم يبخلون فلا ينفقون فيما ينبغي أن ينفق فيه إيثارا لهم بالمال، ويجعلوهم إنماء يحز نون عليهم إن أصابهم مرض ونهوه. أما الأمر الثالث من المشتهيات: فقد عبر عنه القرآن بقوله وَالْقَناطِيرِ الْمُقَنْطَرِة مِنَ

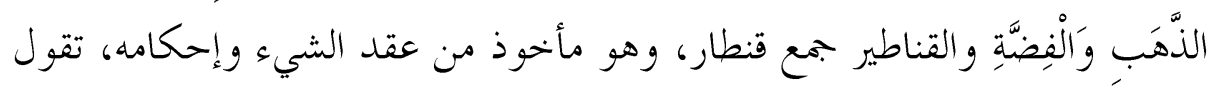
العرب: قنطرت الشيء إذا أحكمته، ومنه سميت القنطرة لإحكامها. قال الفخر الرازي الالقنطار مال كثير يتوثق الإنسان به في دفع أصناف النوائب إدبن

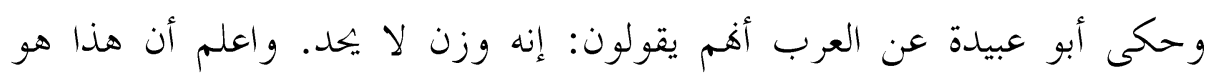
الصحيح، ومن الناس من حاول تحديده. فعن ابن عباس: القنطار ألف دينار أو اثنا

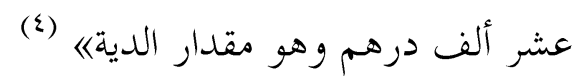

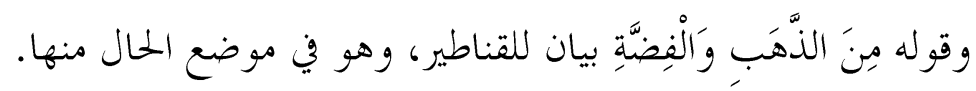

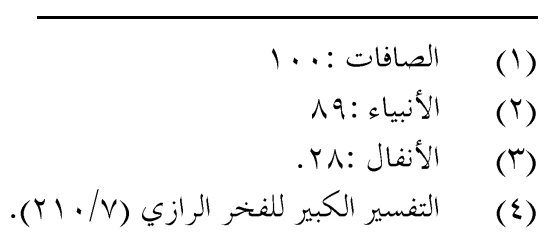




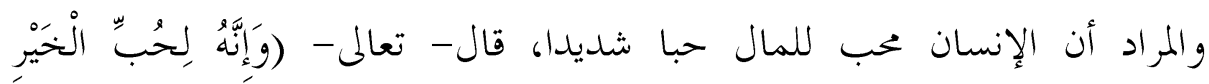

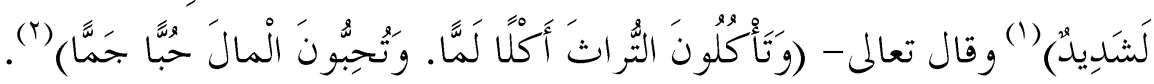

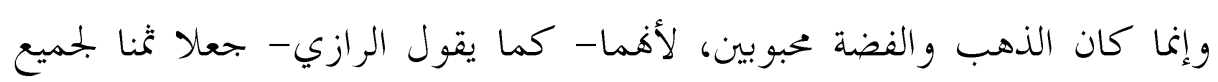

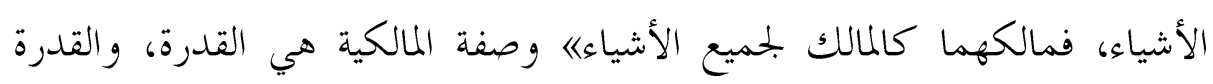

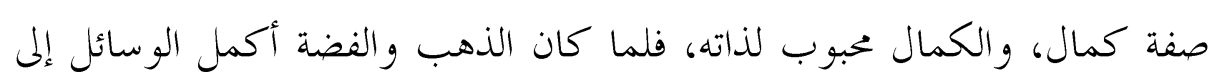

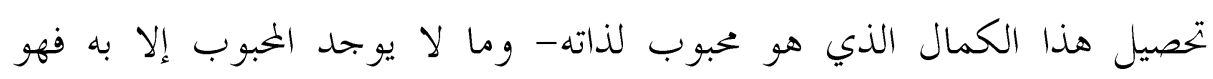

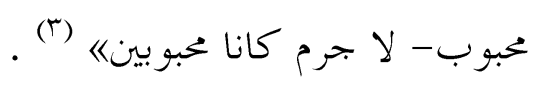
وحب المال كذلك تارة يكون للفخر والخيلاء والتكبر..فيكون مذموما، وناء وتارة يكون للنفقة في وجوه البر فيكون محمودا.

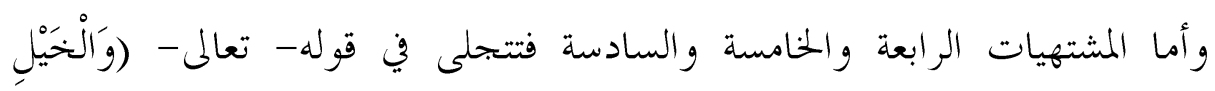

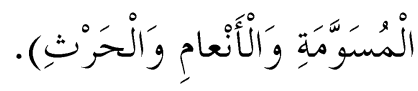

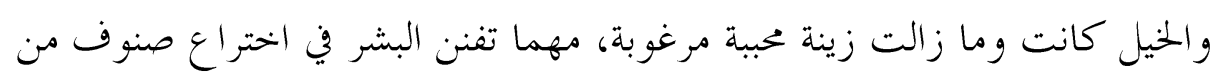

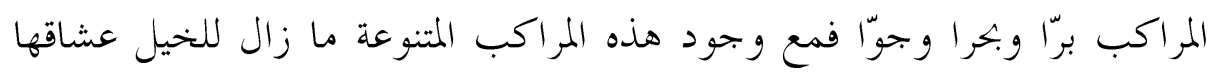

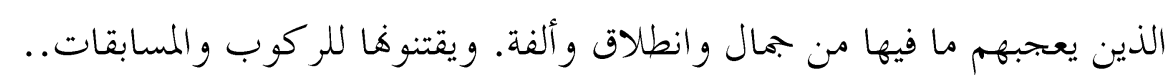
وحب الخيل على ثلاثة أقسام: *تارة يكون ربطها أصحاها معدة لسبيل الله متى احتاجوا إليها غزوا عليها فهؤلاء يثابون. "وتارة تر بط فخرا ومناوأة لأهل الإسلام فهذه على صاحبها وزر.

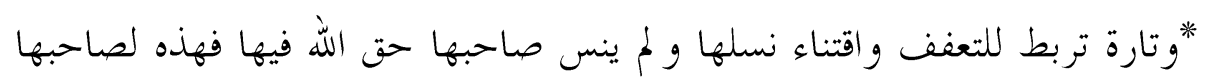

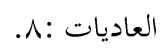

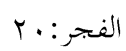

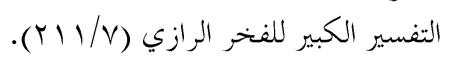

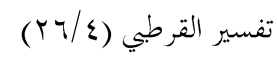


وَالْنَّعامِ جمع نعم، وهي الإبل والبقر والغنم. ولا يقال للجنس الواحد منها نعم إلا للإبل خاصة فإنها غلبت عليها.

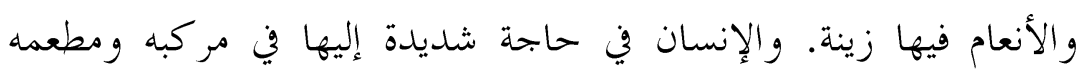

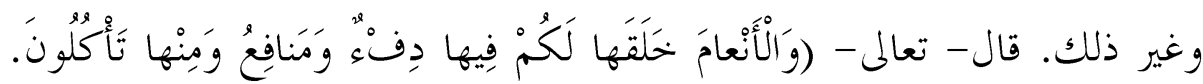

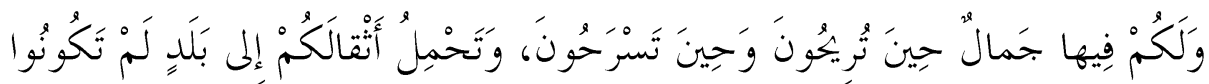

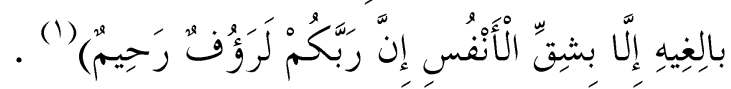

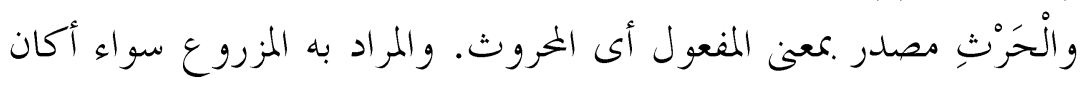

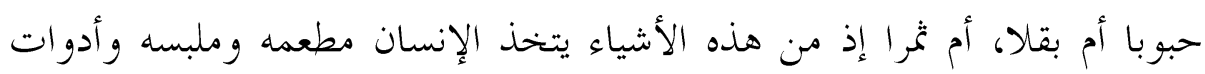
زينته.

تلك هي أهم المشتهيات في هذه الحياة إلى نفس الإنسان قد جمعها القرآن في آية

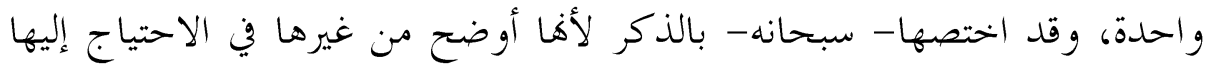

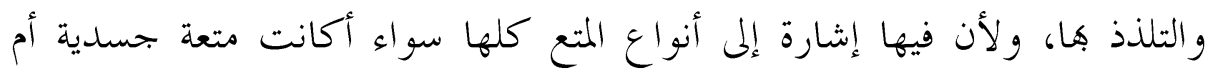

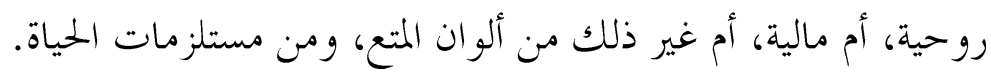
و قد ذكرت الآية الكريمة المشتهيات التي جبل الإنسان على الميل إليها،

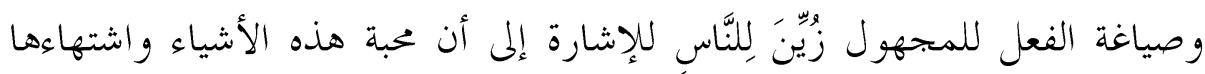
مركوز في الفطرة الإنسانية منذ أوجد. الله الإنسان في هذه الحياة الدنيا.

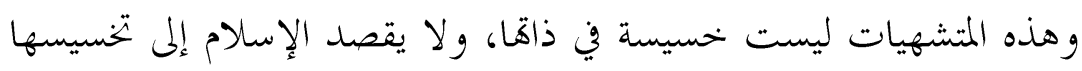

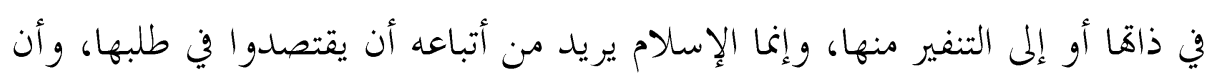

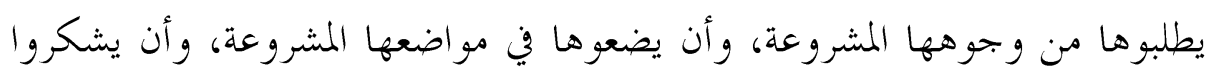

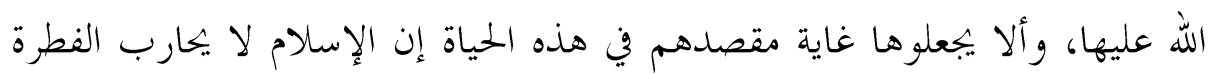

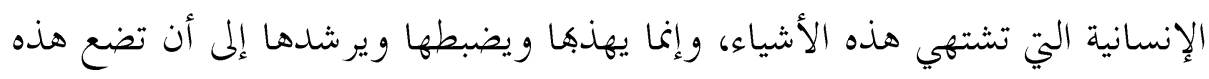

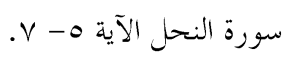


الأشياء في موضعها المناسب، بحيث لا تطغى على غيرها ولا تستعمل في غير ما خلقها الله من أجله، وبذلك يسعد الإنسان في دينه ودنياه و آخرته.

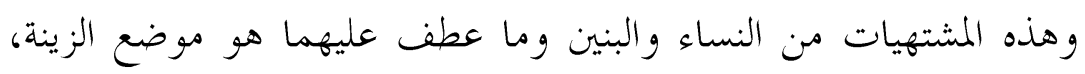
ومطلب الناس الذي يستمتعون به، ويرغبون فيه، ويشتهونه اشتهاء عظيما في وات ولنياء

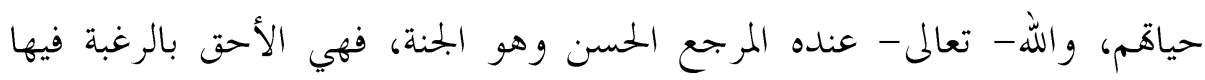
لبقائها دون المتع الفانية.

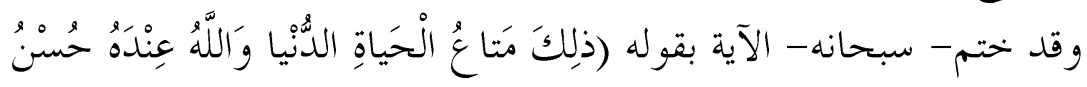

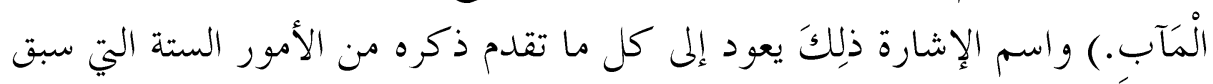

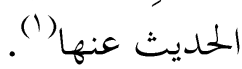

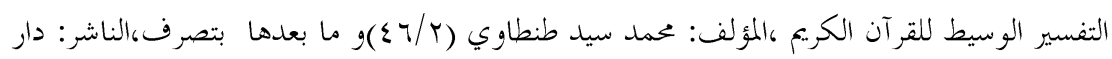

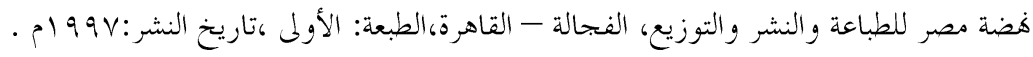




\section{المبحث الثالث :التفسير التحليلي للآية الكربمة :}

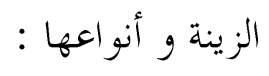

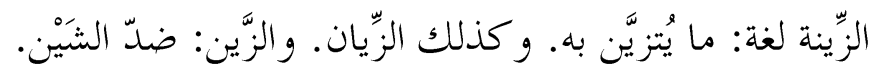

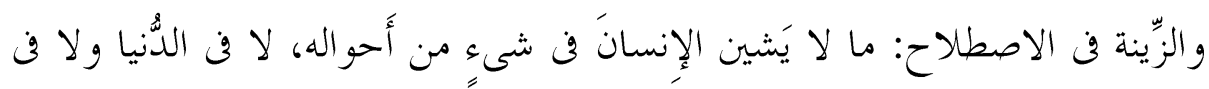

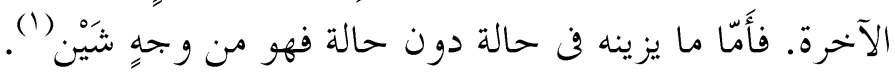

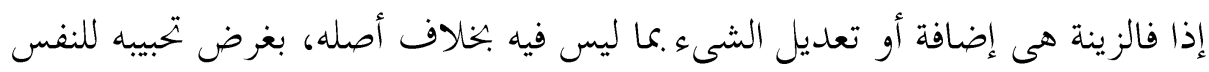

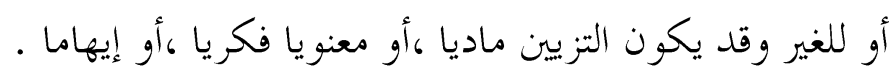

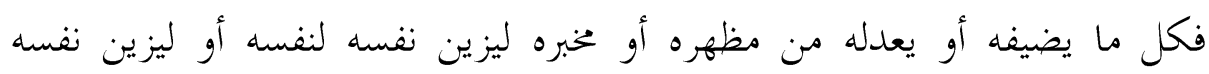

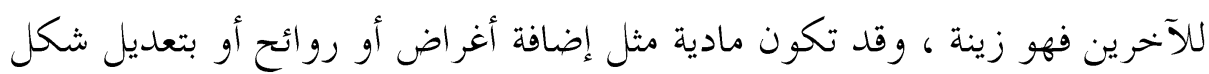

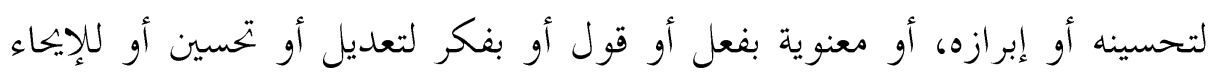

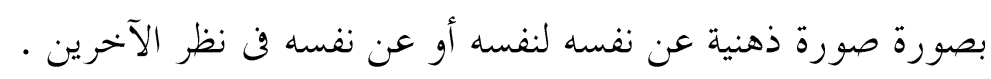

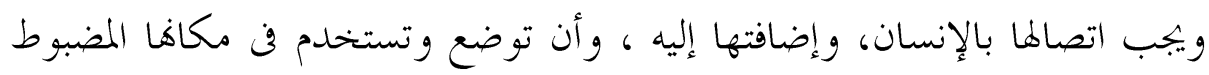

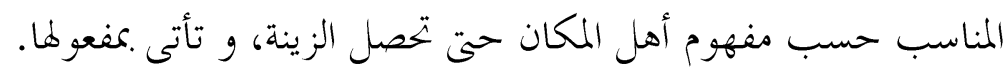

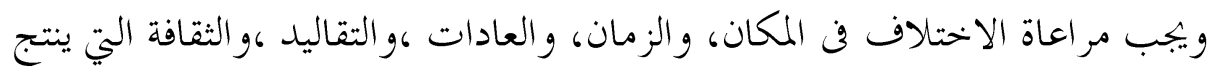

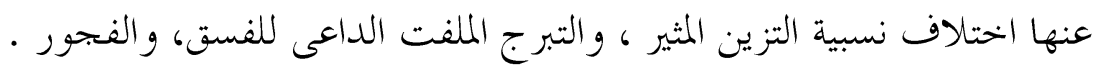

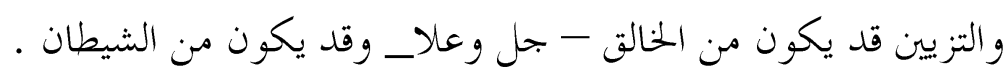

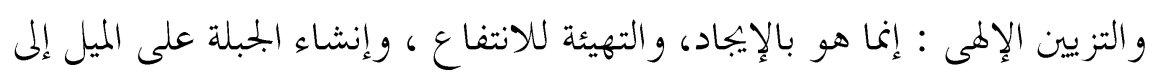
هذه الأشياء. والتزيين الشيطاني : إنما هو بالوسوسة ، والخحديعة ، وتحسين أخذها من غير وبوهها.

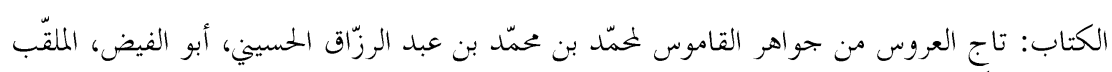

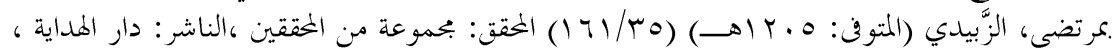

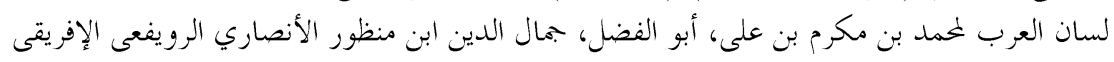

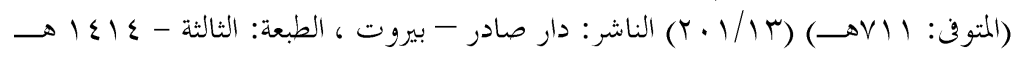




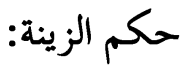

الأصل في الزينة الإباحة ، فجميع أنواع الزينة مباح مأذون فيه إلا ما خصصّه

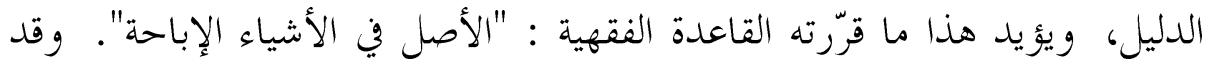

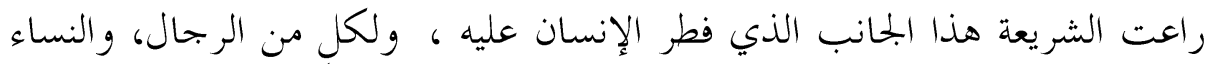

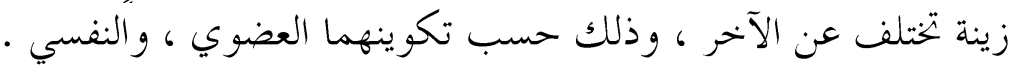

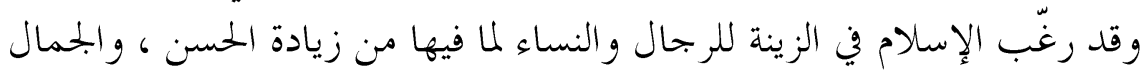

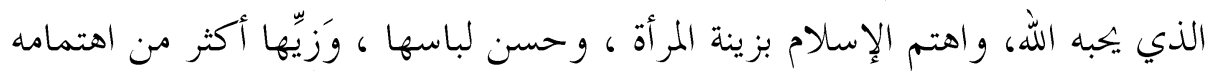

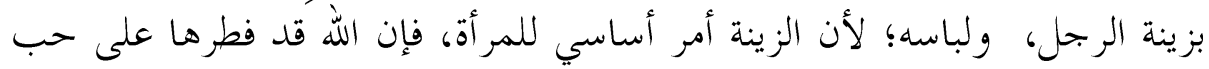

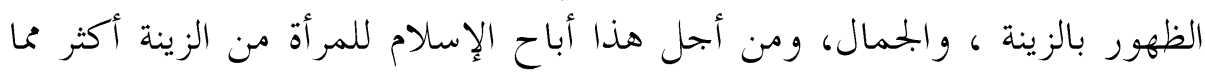

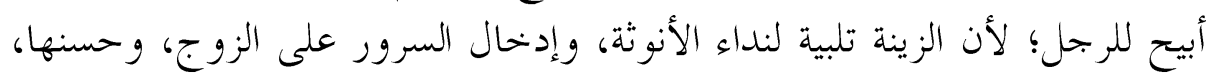

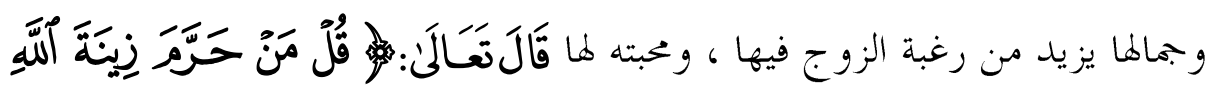

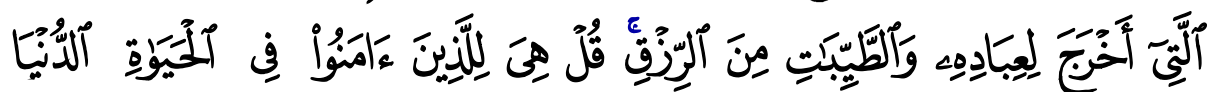

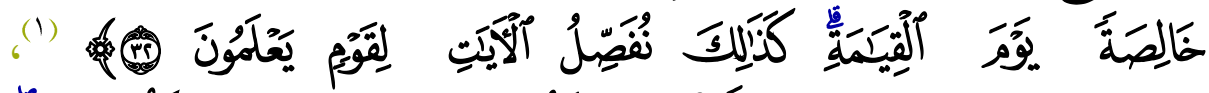

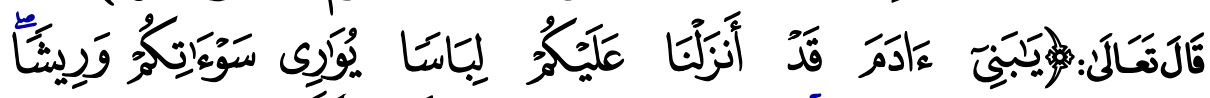

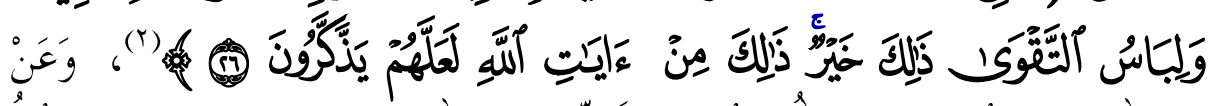

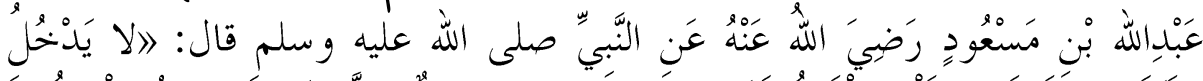

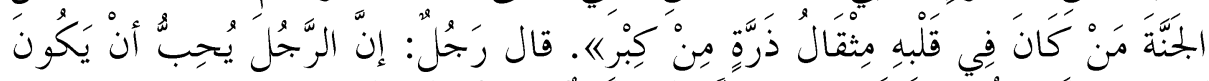

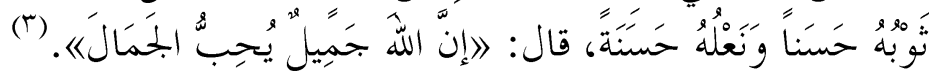

$$
\begin{aligned}
& \text { الأعر اف:بr. } \\
& \text { الأعراف:بr. }
\end{aligned}
$$

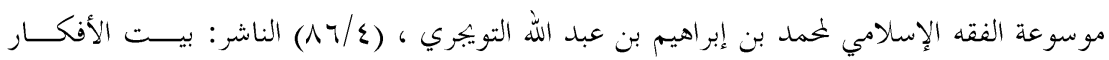

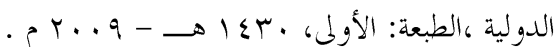

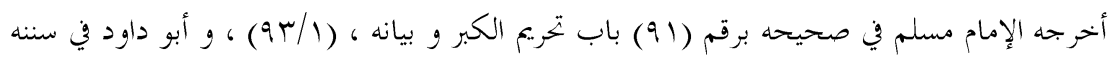

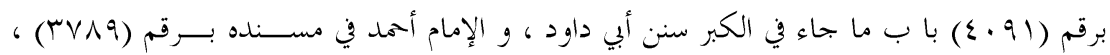

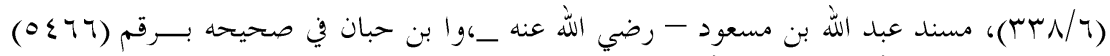

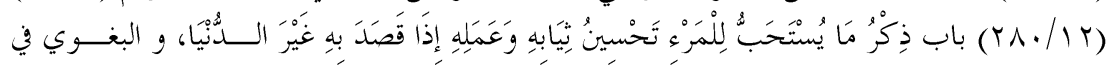

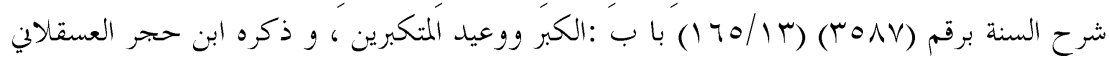

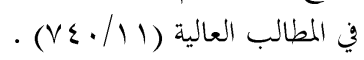




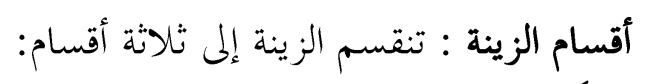

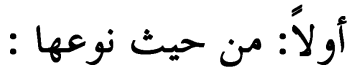

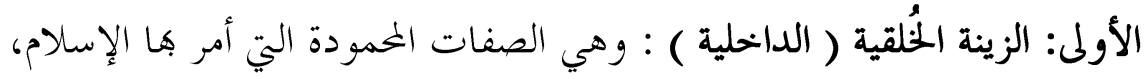

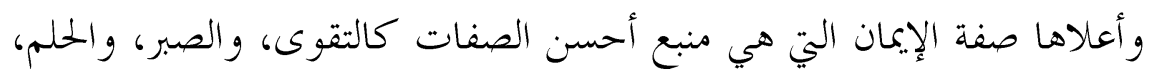

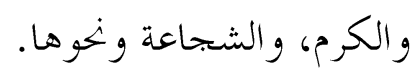

الثانية: الزينة المكتسبة: وهي كل زينة خارجة والكة عن المسبم المزين ها كاللباس ،

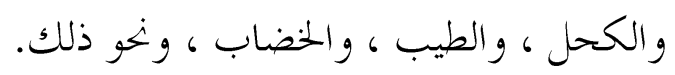

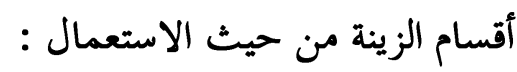

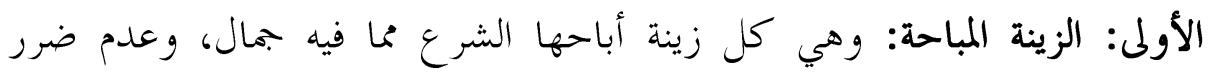
كألو ان الثياب، والحرير، والحلي، والمي، والطيب، ووسائل التجميل المباحة (للنساء)، ونهو

ذلك.

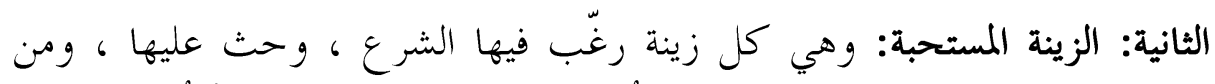

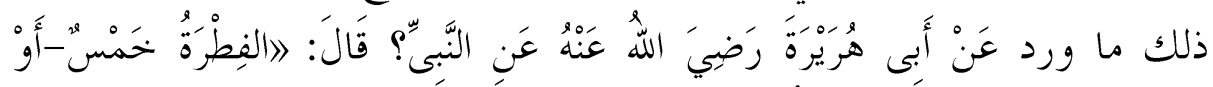

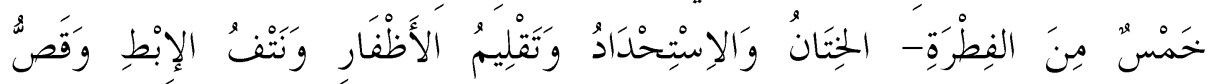

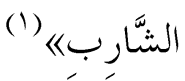

الثالثة: الزينة المحرمة: وهي كل ما حرمه الشرع ، وحذر منه، منا تعتبره النساء زينة،

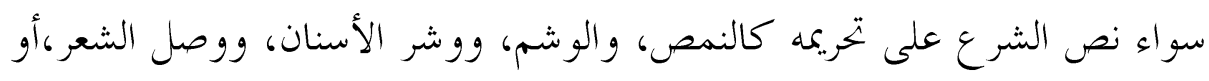
كان عن طريق التشبه.

ففاعل المررم يستحق العقاب، ومن تركه امتثالاً فهو مثاب، وفاعل

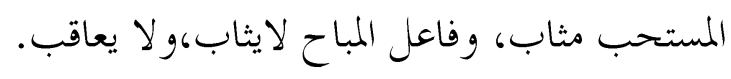

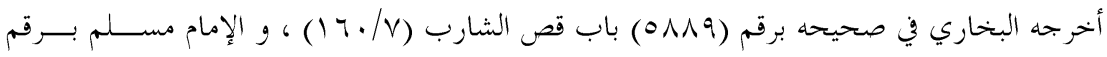

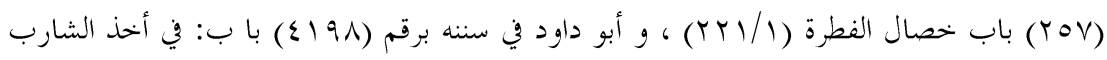

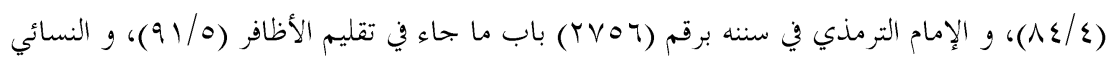

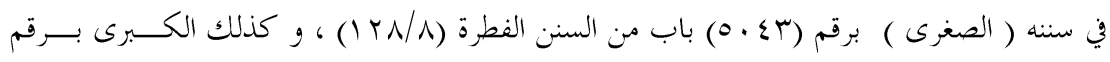

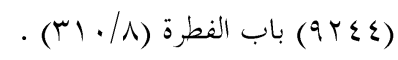


فإن كان المباح وسيلة فحكمه حكم ما كان وسيلة إليه فالطيب مثلاً

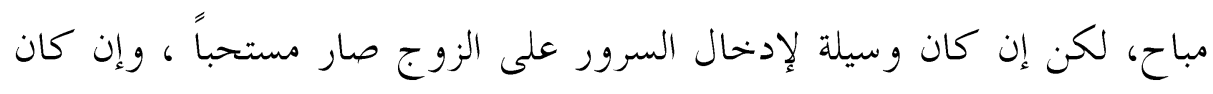

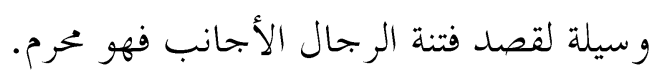

ومن الزينة المباحة للنساء :

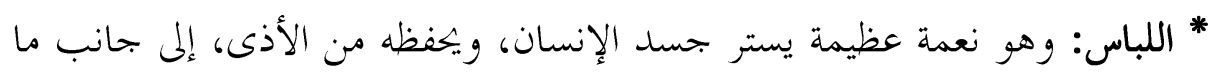

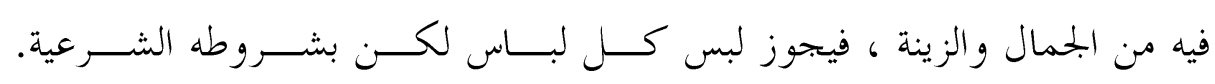

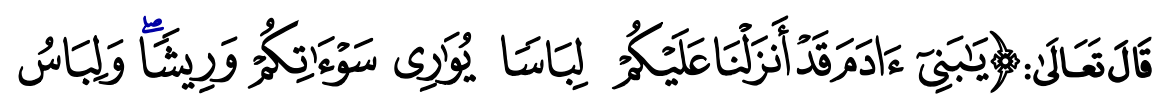

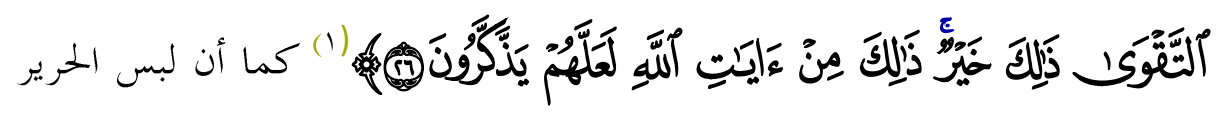
حلال للإناث فقط دون الذكور.

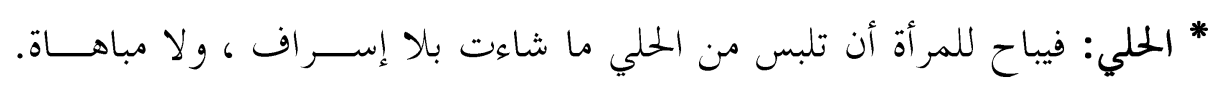

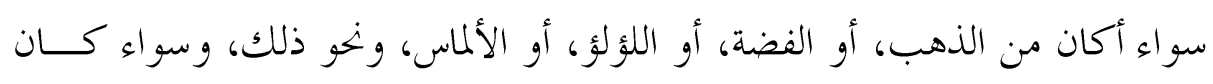

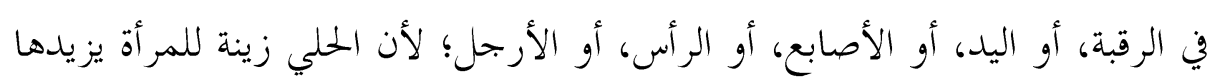

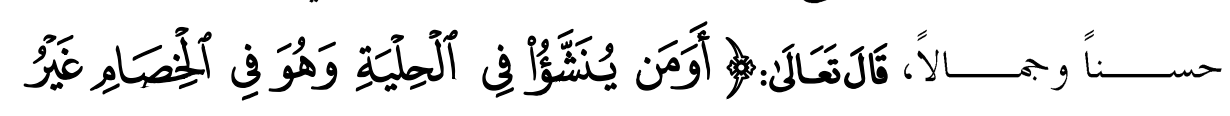

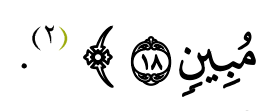

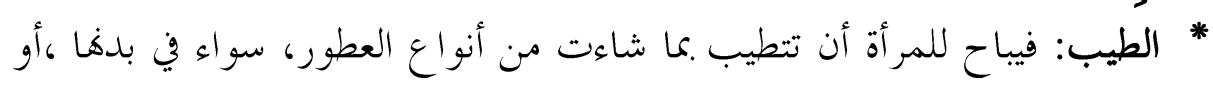

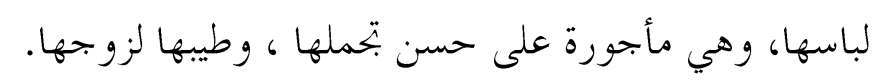

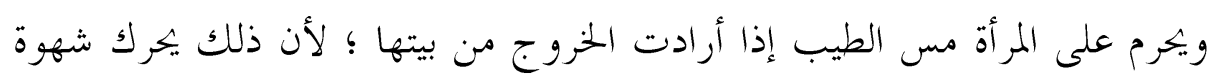
الرجال، ويلفت أنظارهم. * الكحل: وهو زينة وجمال، والكحل بالإنمد زينة ودواء.

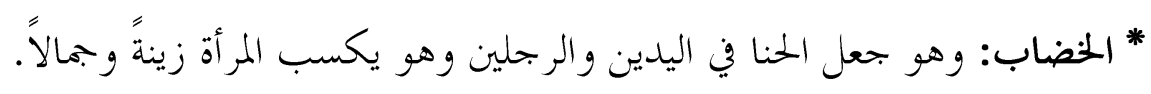

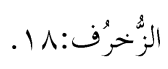


* تسريح شعر الرأس وتنظيفه والعناية به بتملاً للزوج.

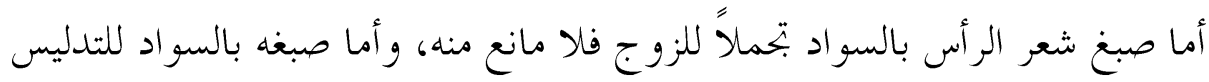

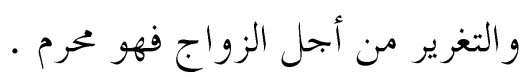

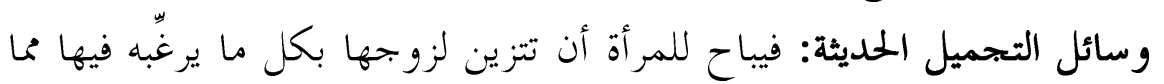
ليس فيه مخذور شرعي. فيباح لما التز ين بما ظهر من الأصباغ و والمساحيق الحديثة بشروط منها:

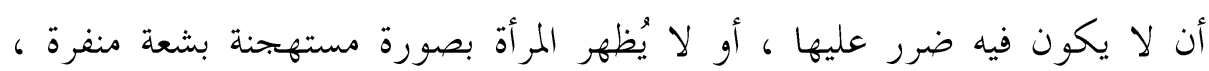

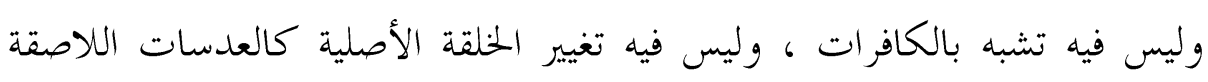

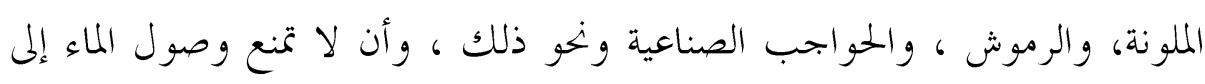

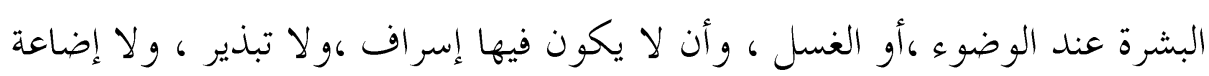
لألأوقات في شر ائها، واستعمالها.

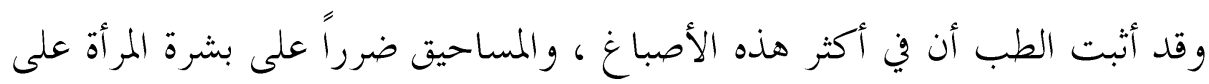

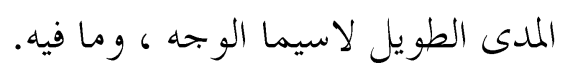

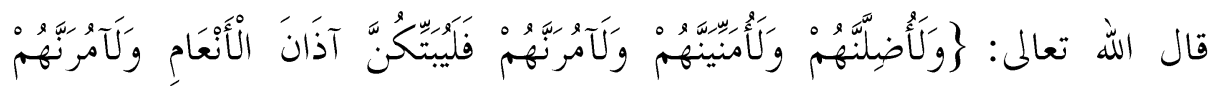

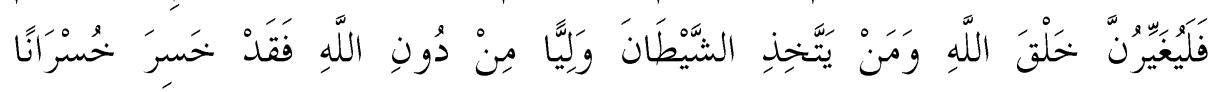

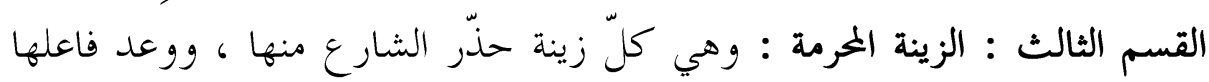

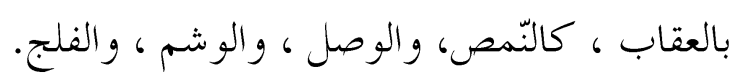

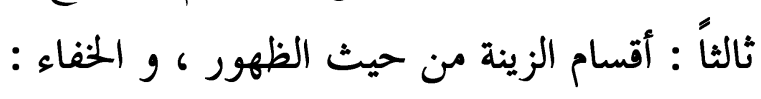
ا - الزينة الظاهرة : وهي التي بمكن أن تظهر أمام غير المحارم.

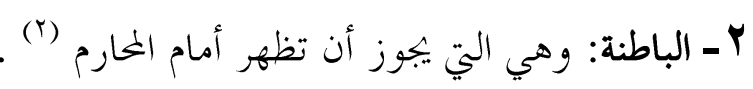

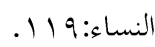

الرأي الصواب في الزينة و الحجاب لجو اد موسى عفانة ص ، 1 و ما بعدها باختصار ، الطبعة الثانية

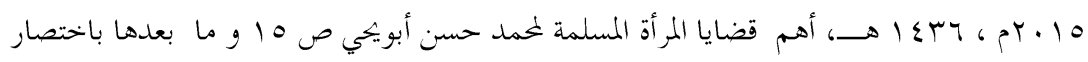

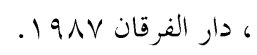




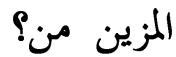

قال أهل السنة: المزين هو الله تعالى ؛لأنه تعالى خالق لمجيع أفعال العباد ، ولأن الله

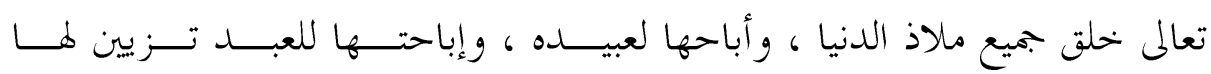

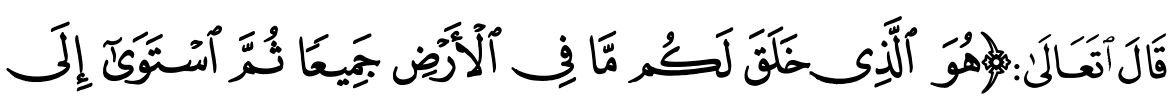

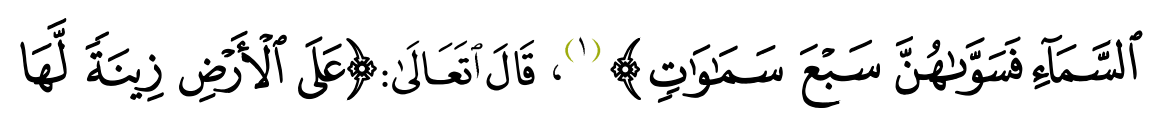

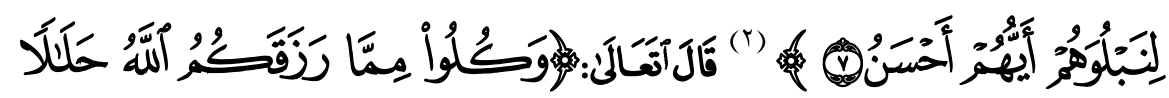

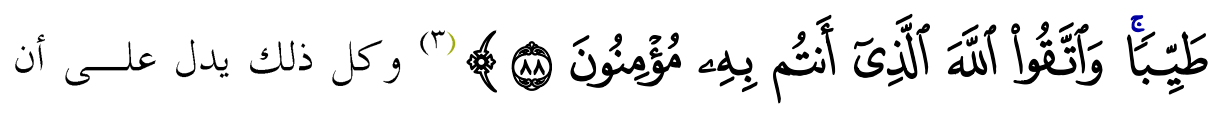
المزين هو الله تعالى.

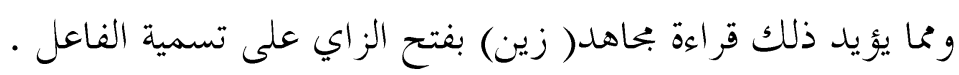

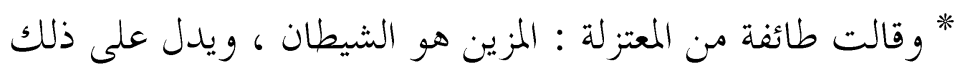
* أن الله تعالى زهد في هذه الأشياء بأن أعلم عباده زو الها. المان.

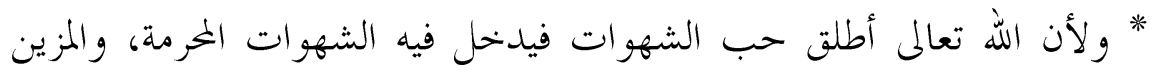

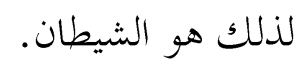

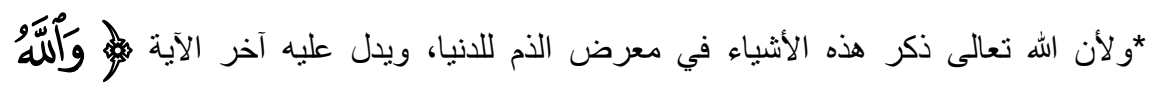

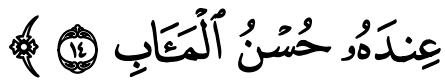

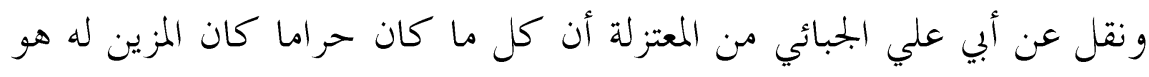

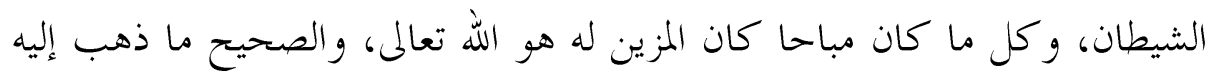

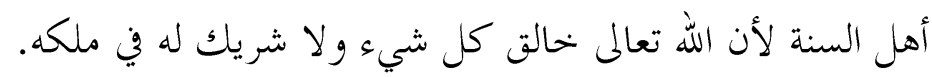

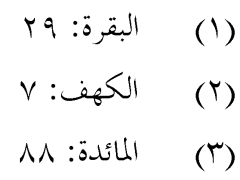


والآية حجة على المعتزلة والقدرية ؛ لأن الزينة نظير المشيئة، لأهم يبدوها في

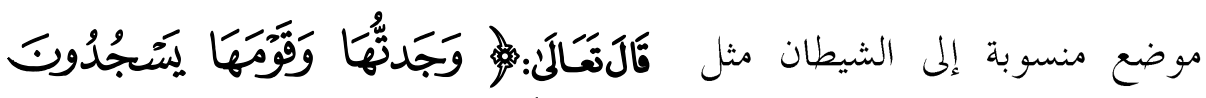

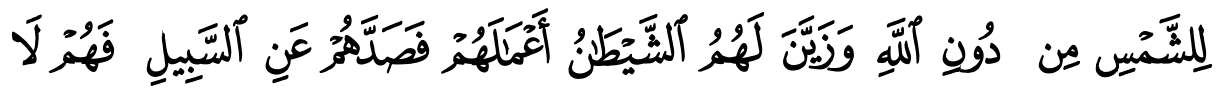

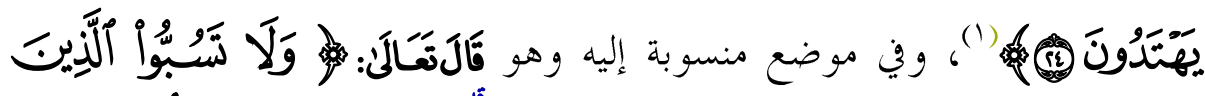

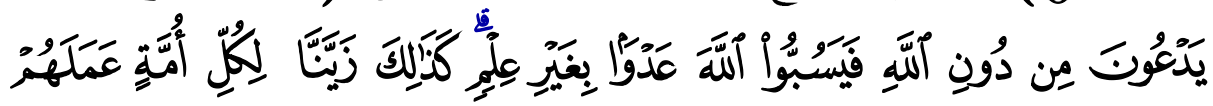

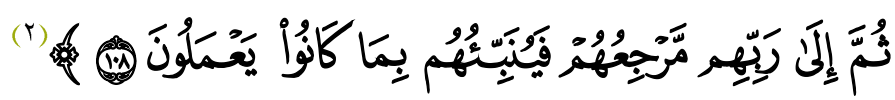

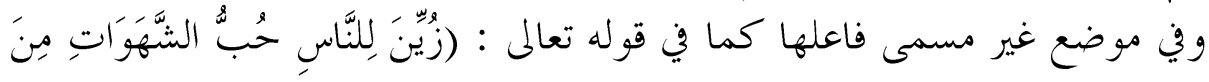
النّّسَاء) وأشباهها، فقطع جل جلاله الريب كله وأخبر أن الشيطان نقيض لذلك غير سـابق

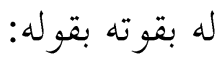

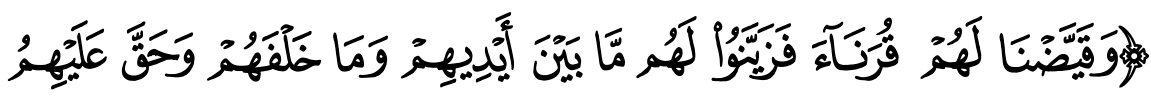

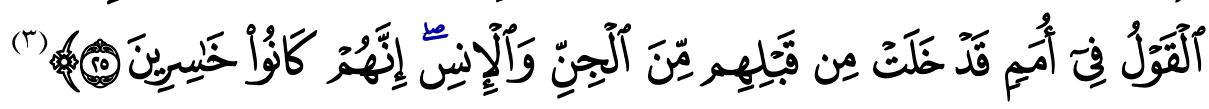

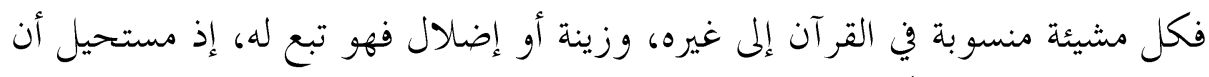

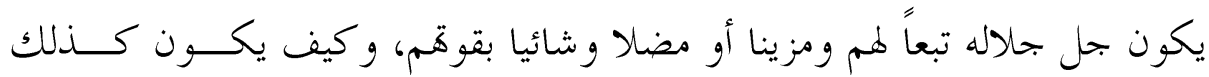

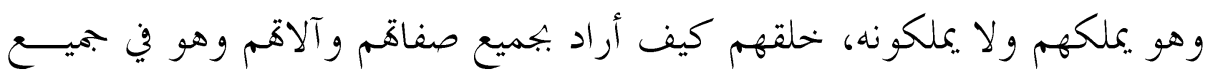

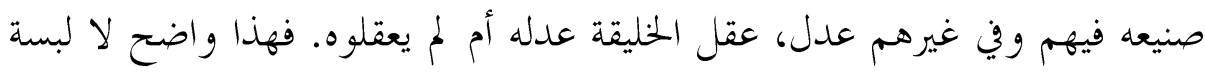

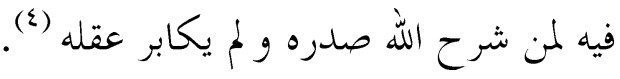

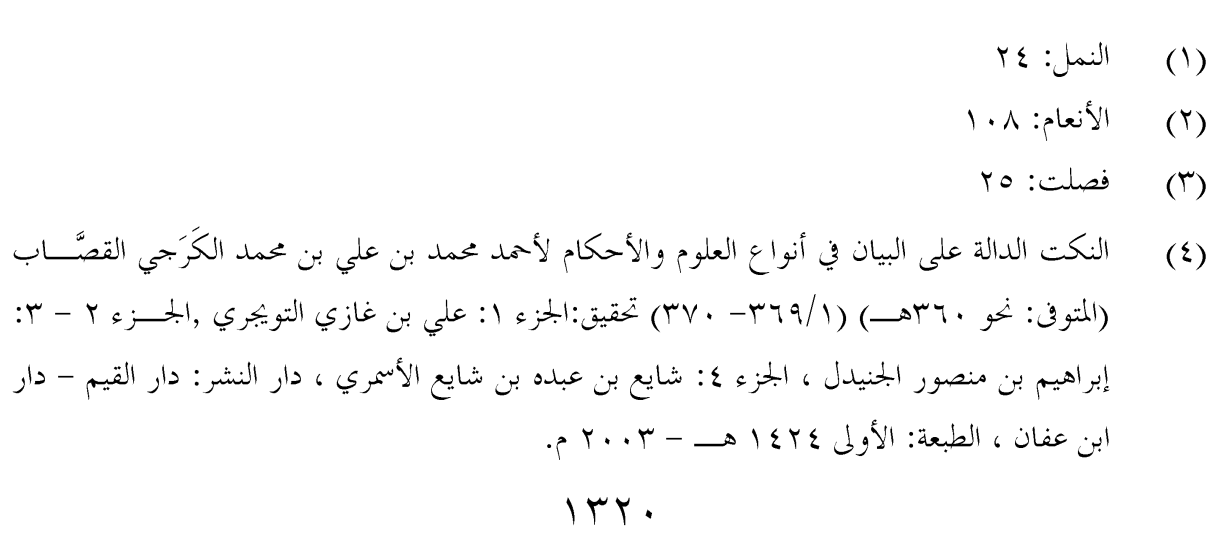


و كلمة ازيُيِّنَ تعطينا فاصلا بين المتعة التي يحلها الله، والمتعة التي لا يرضاها الله؛ لأن

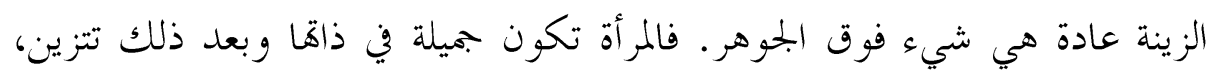

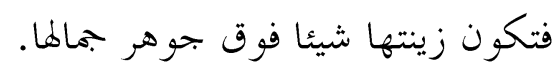

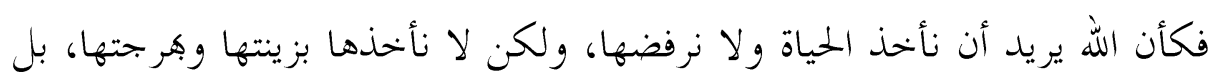

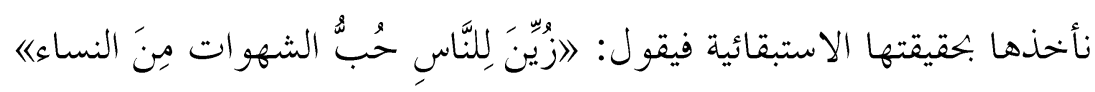

سر التعبير بلفظ الشهوات :

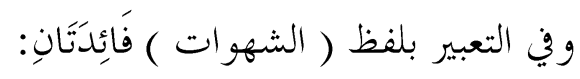

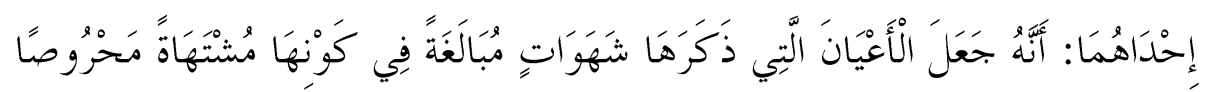

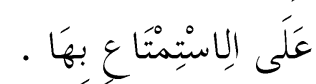

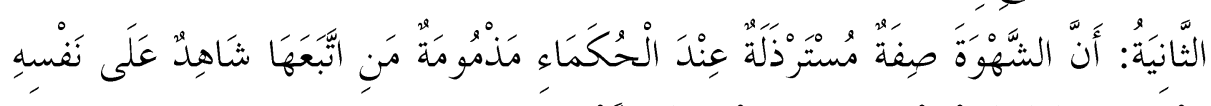

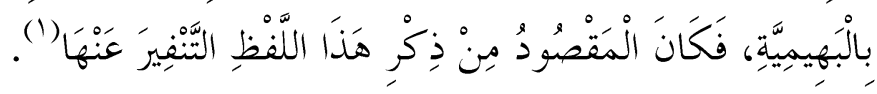
الفرق بين الشهوة والغريزة والنعمة: الشهوة : هي ميل النفس بقوة إلى أي عمل ما.

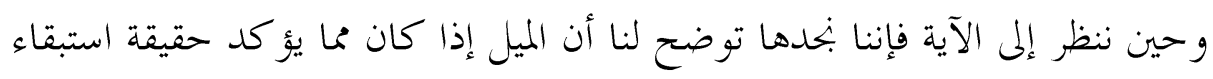

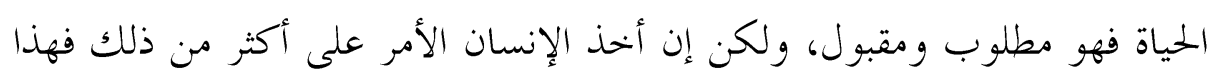
هو الممقوت. الغريزة: الطبيعة والقريحة والسجية، وفِي الفلسفة صُورَة من صور النشاط النَّْْبِّ

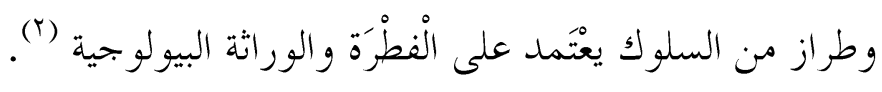

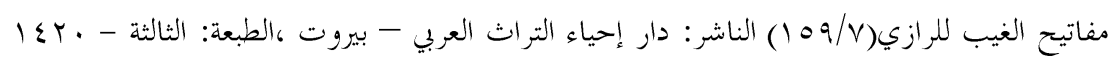

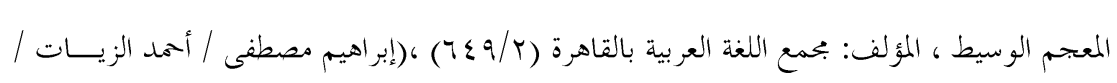

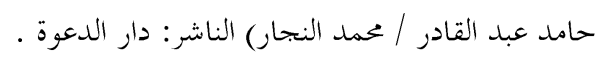

$\mid$ ThI 
إذا،فالغريزة فطرة ربانية لا تكتسب ،إذ توجد في النفس بدون تدخل من الإنسان،

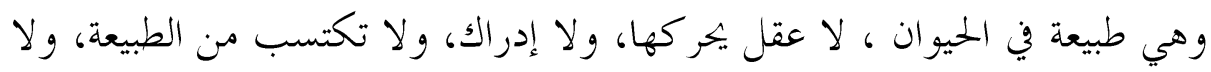

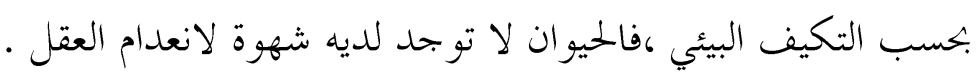

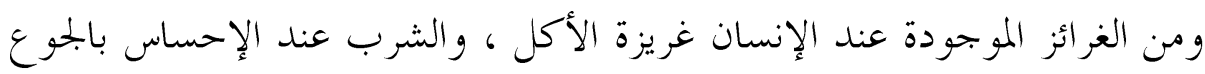
، أو العطش ، و كذلك الجماع لسد الرغبة الجنسية و التكاثر .

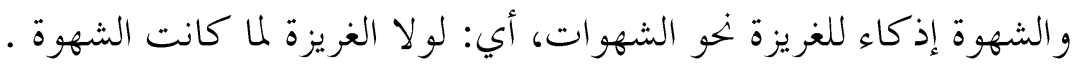
حيث،يو جد تشابه واختلاف بين الغريزة و الشهوة ، و كيفية ارتباطهما . مثال ذلك الإنسان ككائن حي يحتاج الم الطعام والشراب ليبقى على قيد الحياة ، ووي حالة الجوع و العطش تتحرك الغريزة لتنبه العقل إلى ذلك.

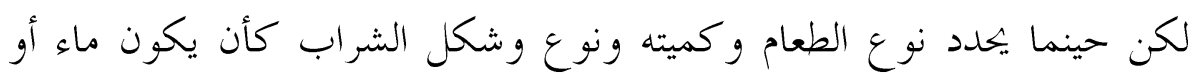
عصير فواكه وغيره ، وقد لايكون الإنسان هنا جائع أو عطش ، هذا ولتهر التحريك و الطلب المعين في وقت لايكون الجسم فيه جائع أوعطشان يسمى شهوة لا غريزة.

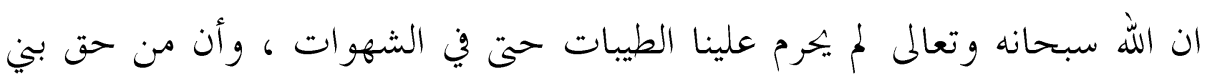
آدم مهما كان منصبه أن يتشهى ماحلل من طيبات الحياة الدنيا مالم يصب حراماً.

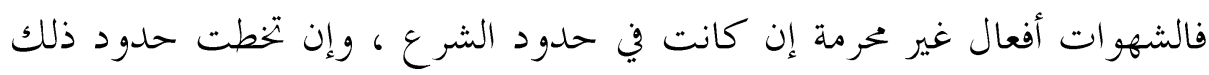

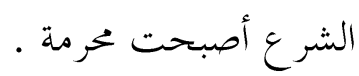

النعمة : لغة: الخفض - خفض العيش - والدعة والمال ،وجمعها نعم وأنعم .

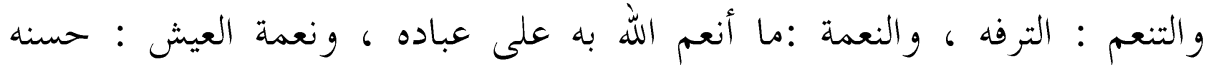
ونضارته (1)

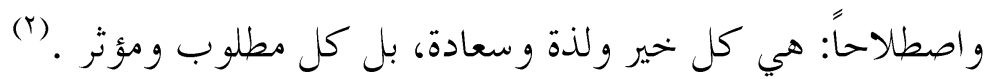

$$
\begin{aligned}
& \text { لسان العرب لابن منظور ( }
\end{aligned}
$$

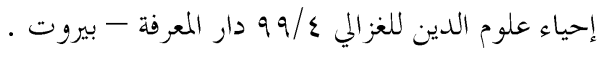


وقال الرازي هي: المنفعة المفعولة على جهة الإحسان إلى الغير ، وهي على ثلاثة

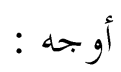
أحدها : نعمة تفرد هما اللّ كالخلق و الرزق .

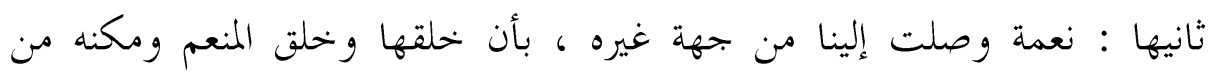

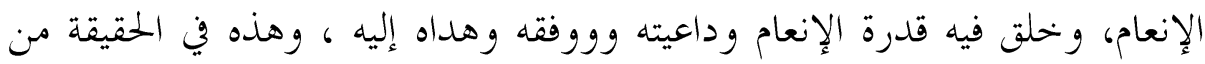

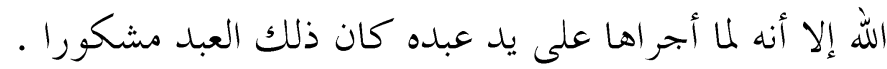

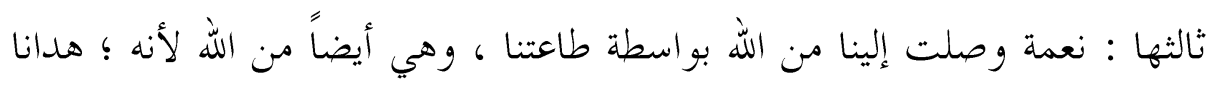
إلى الطاعات وأعاننا عليها (1)

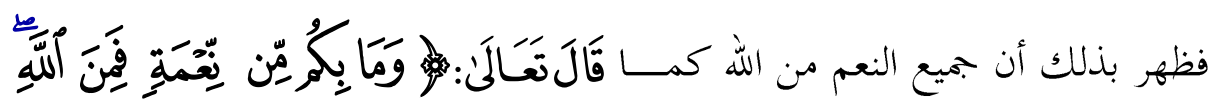

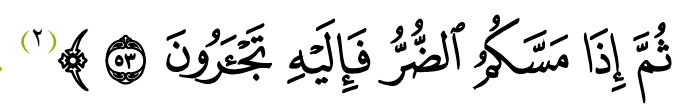

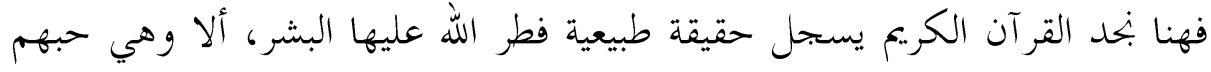

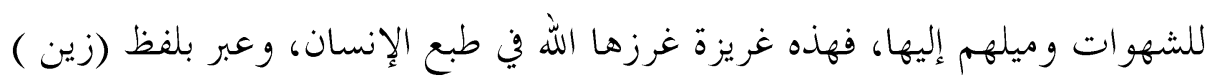

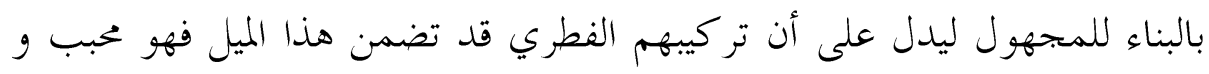

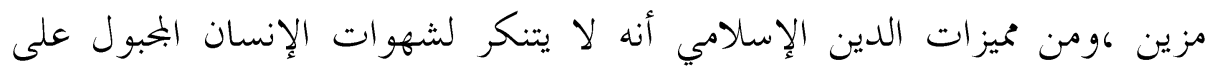

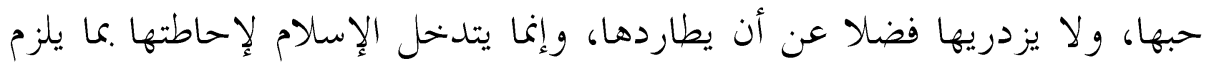

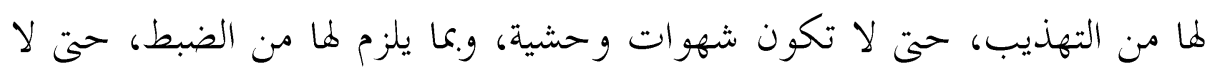

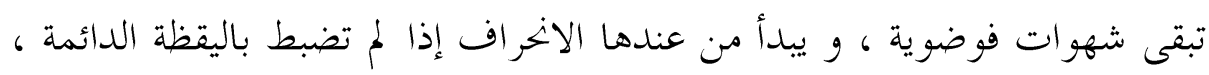

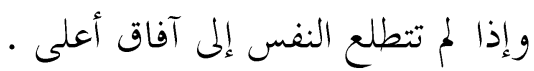

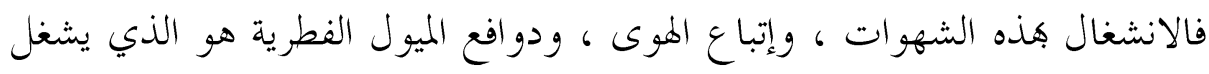

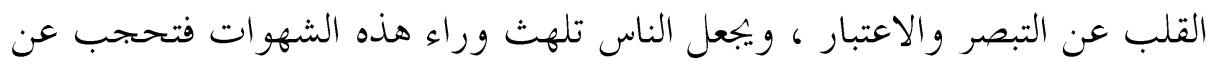

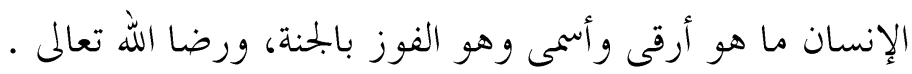

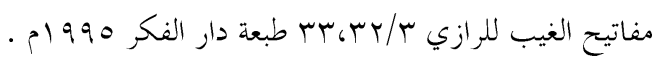

$$
\begin{aligned}
& \text { النحل: مل }
\end{aligned}
$$




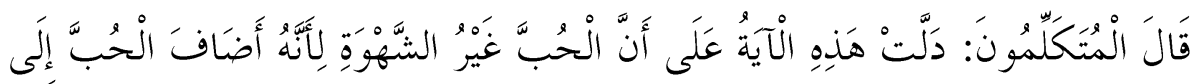

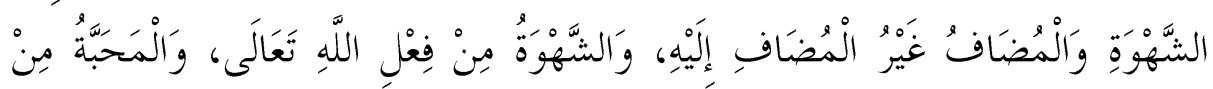

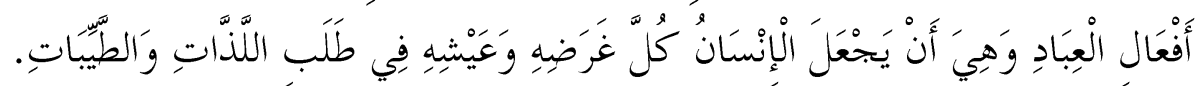

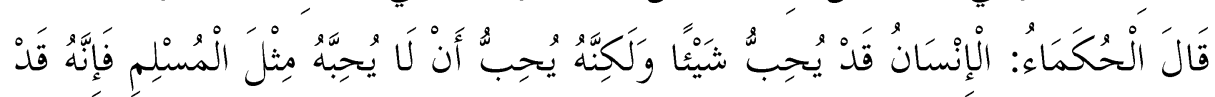

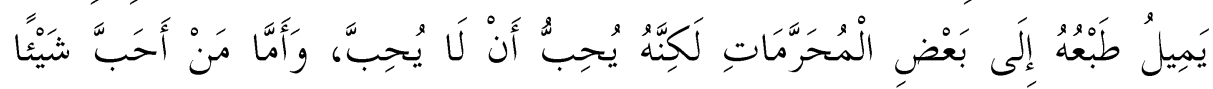

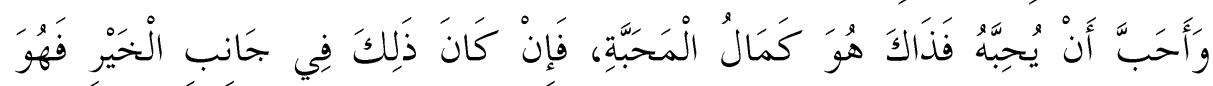

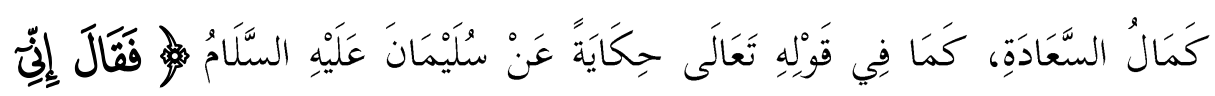

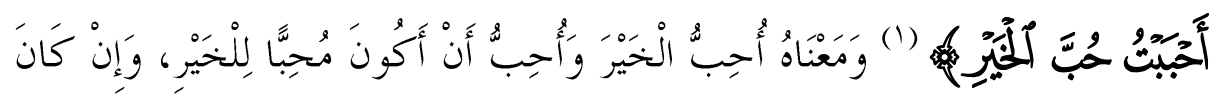

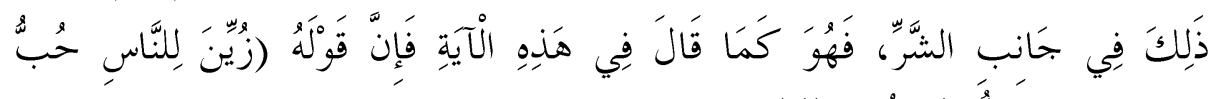

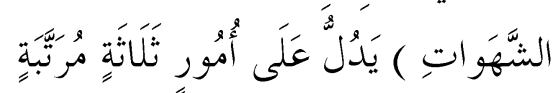

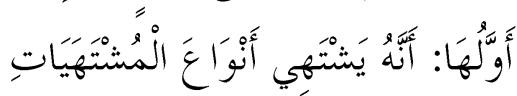

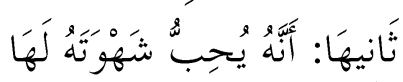

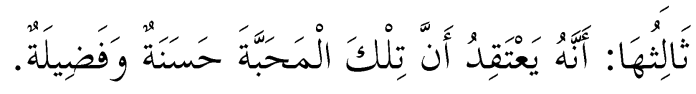

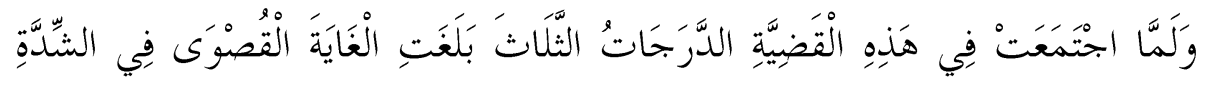

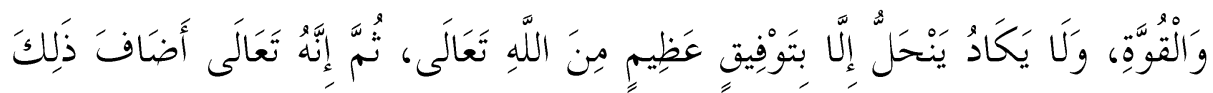

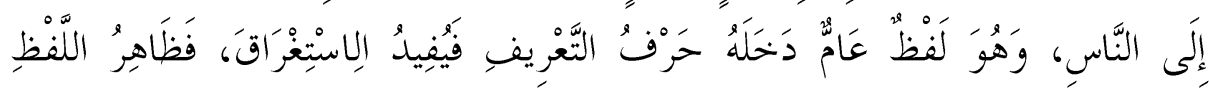

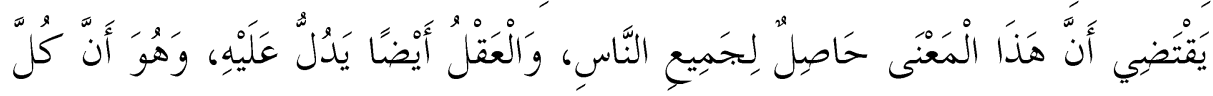

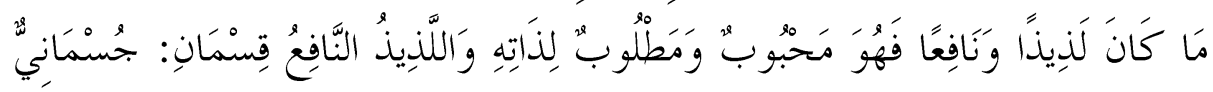

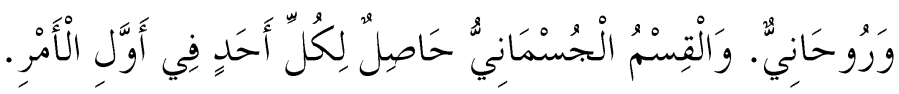




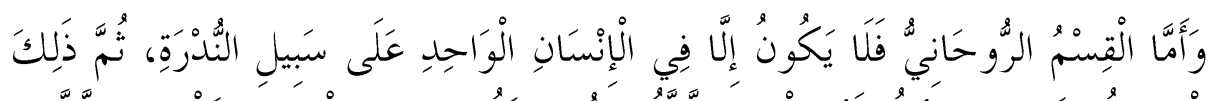

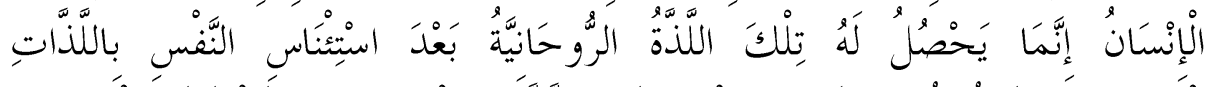

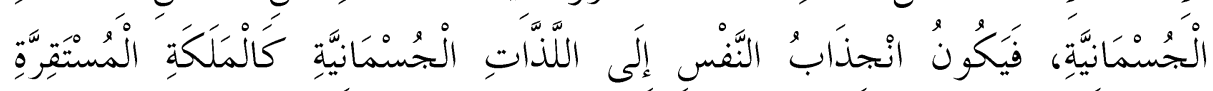

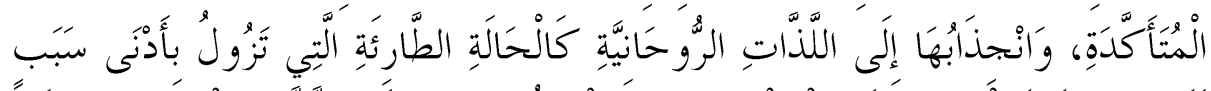

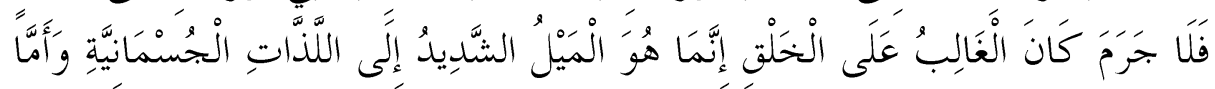

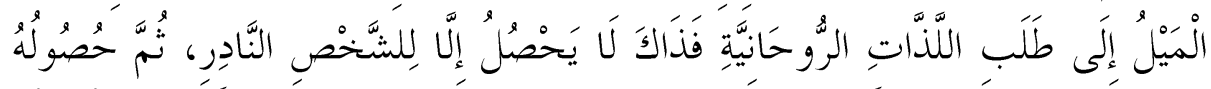

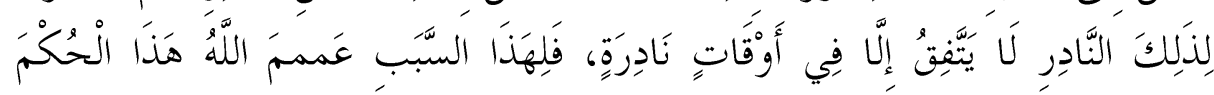

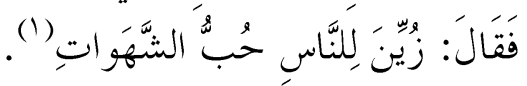

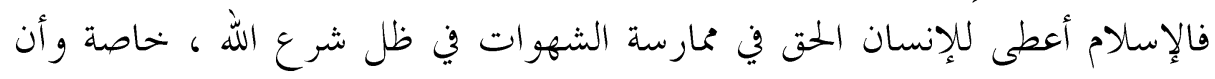

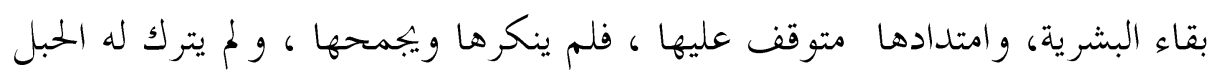

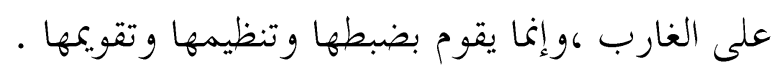

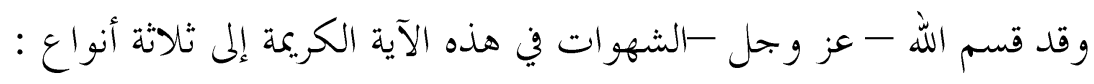

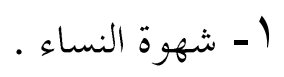

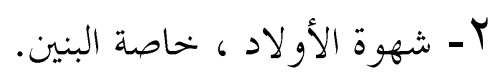

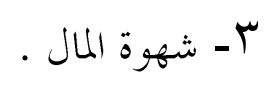

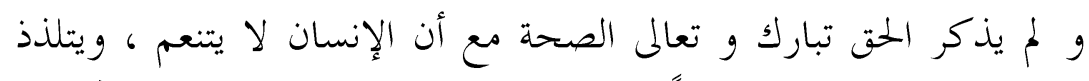

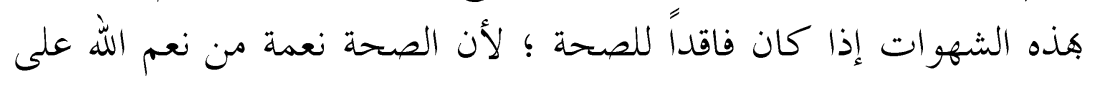

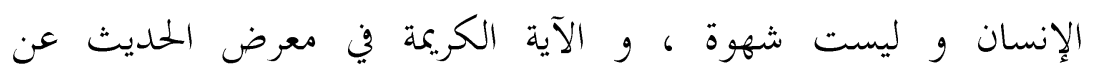

$$
\text { أولاً : شهوة النساء : الشهوات }
$$

إن أقوى الشهوات في نفس الإنسان العادي هي شهوة النساء اللاتي يوفرن لأزواجهن جوا من المودة والرحمة والاستقرار.

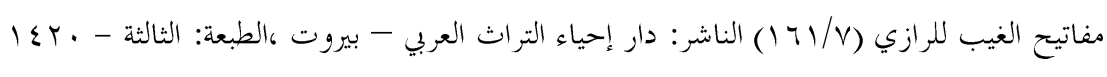




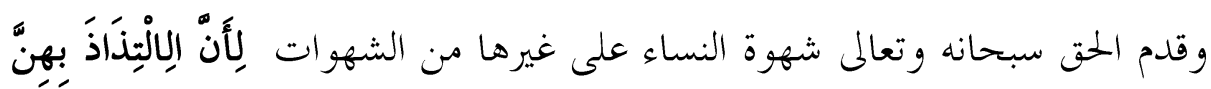

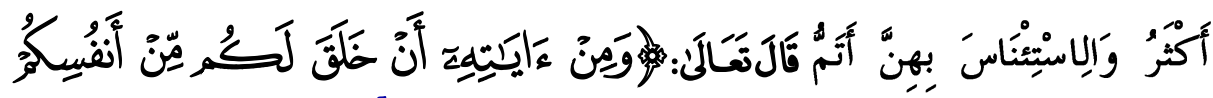

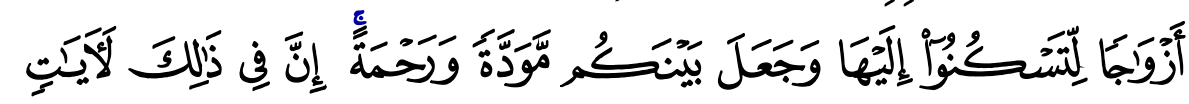

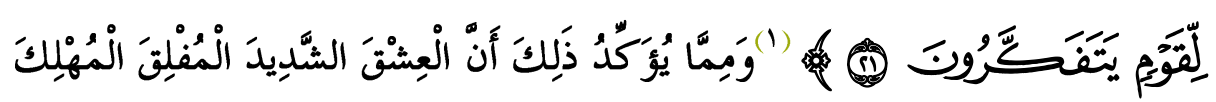

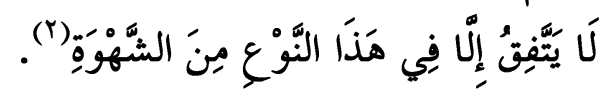

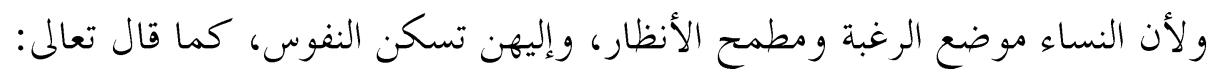

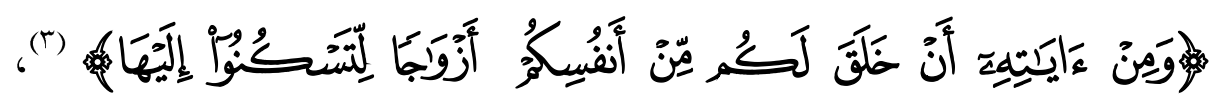

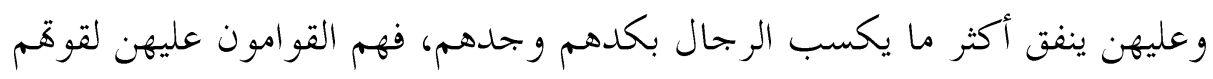

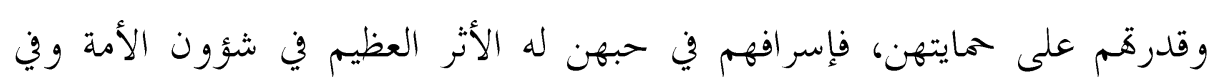
إضاعة الحقوق أو حفظها.

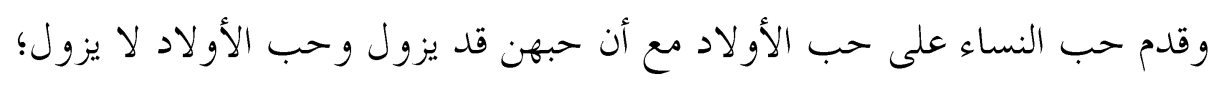

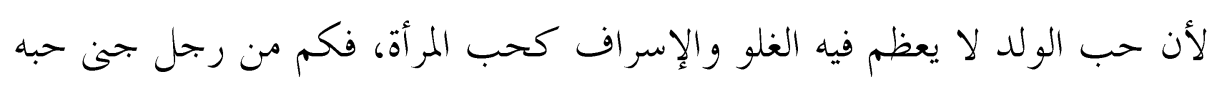

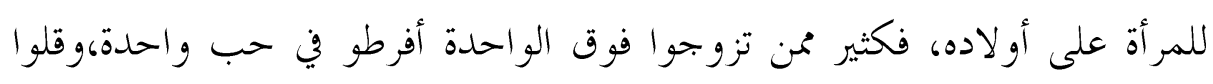

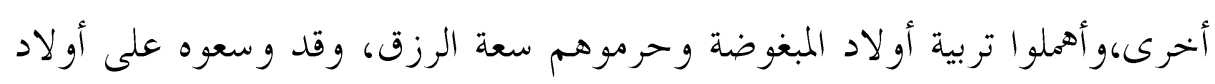

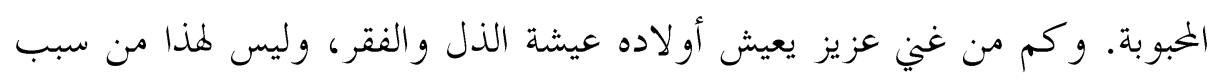

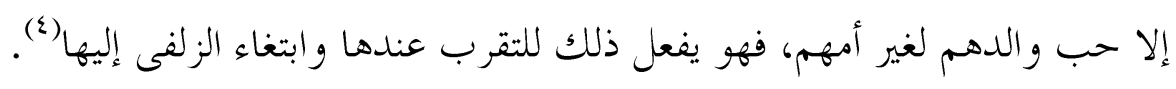

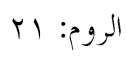

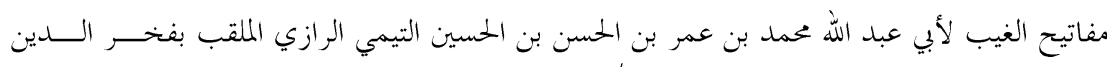

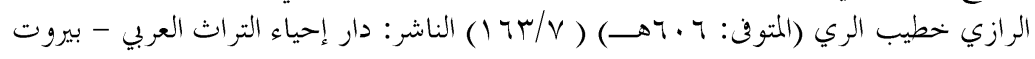

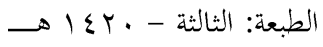

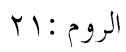

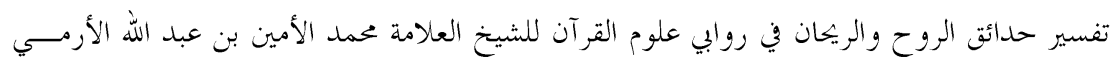

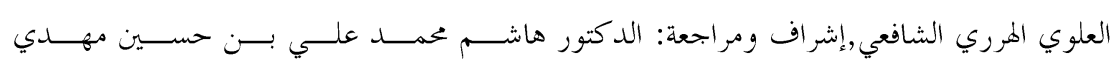

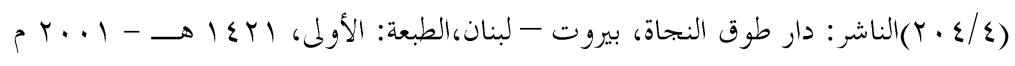




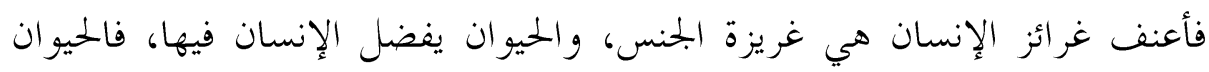

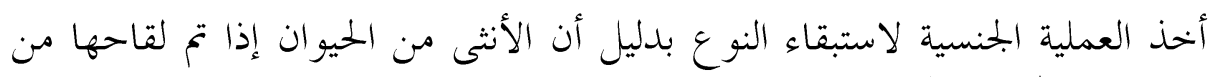

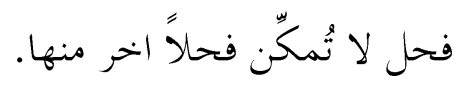

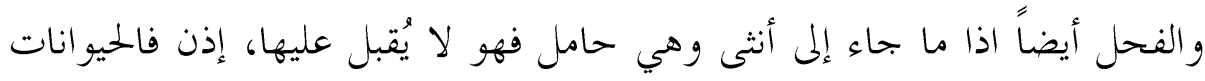

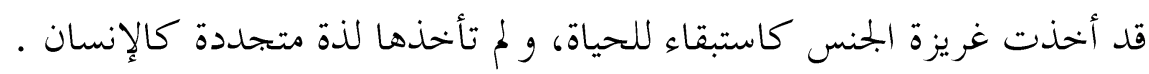

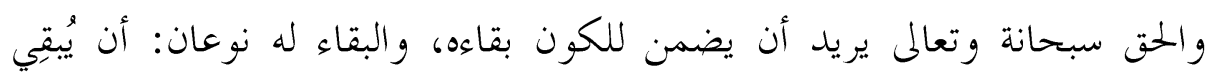

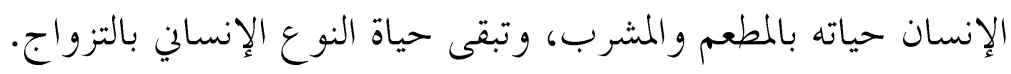

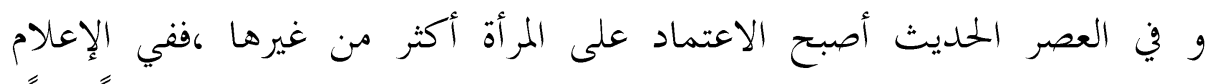

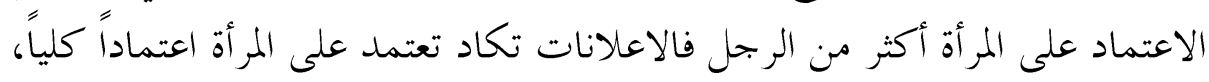

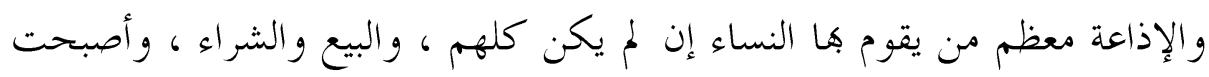

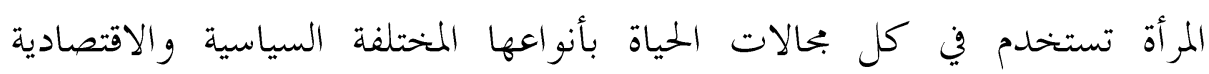
والاجتماعية من أجل تحقيق أهداف مختلفة.

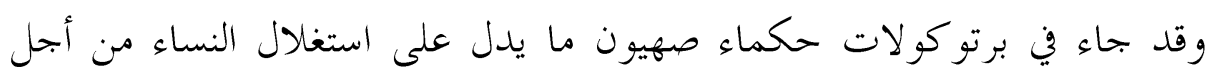

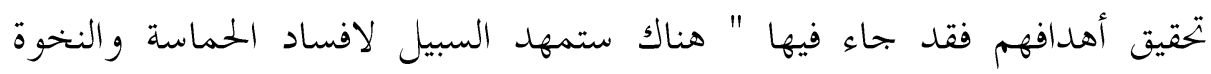

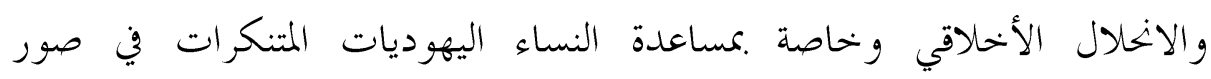

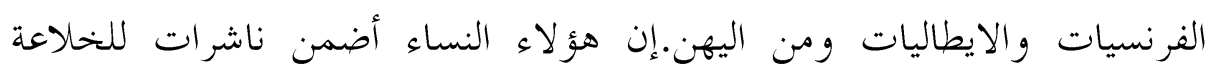

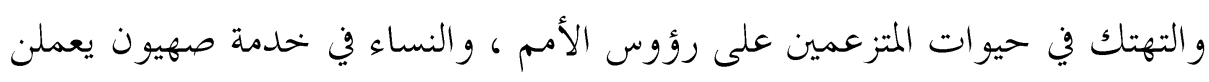

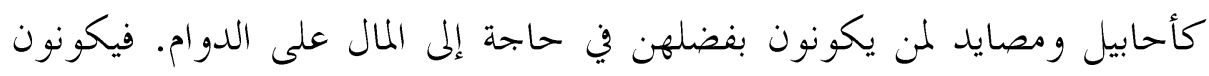

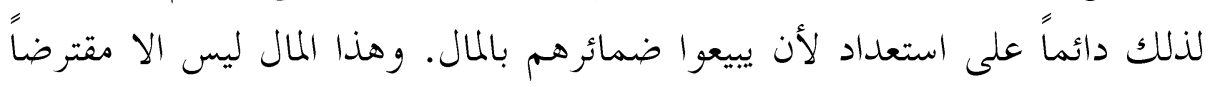

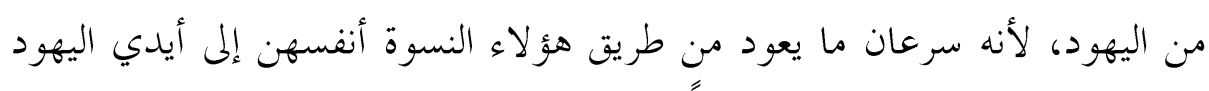

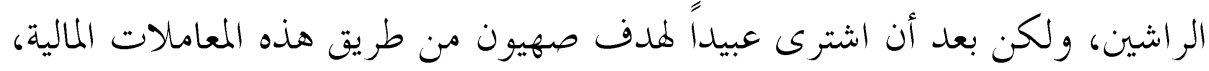

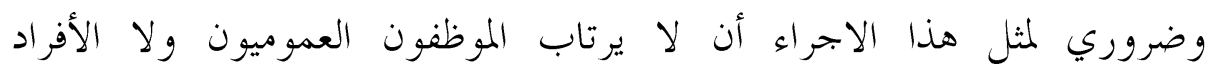

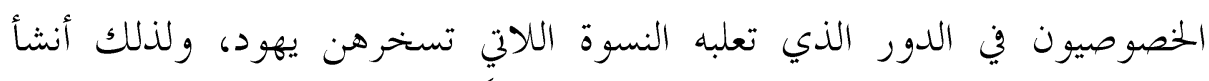

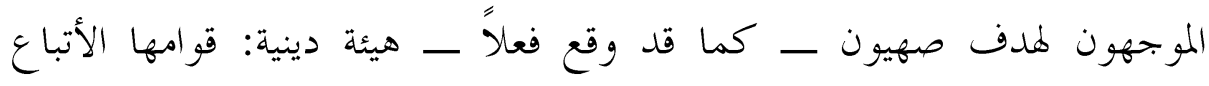
المخلصون للشريعة الموسوية وقوانين التلمود، وقد اعتقد العالم كله فوله ان حجاب 


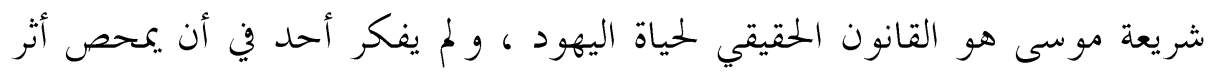

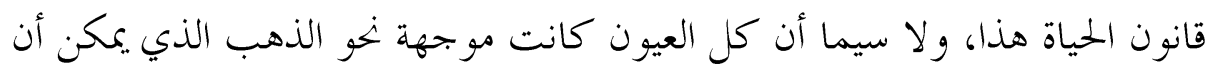

تقدمه (1) (1) " ليلاحظ أن كثيراً من زعماء الأمم و المشهورين فيها كالعلماء والفنانين والادباء

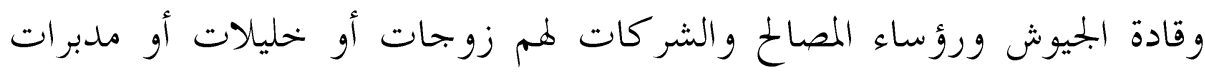

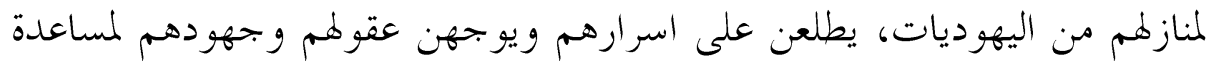
اليهود أو العطف عليهم أو كف الاذى عنهم وهن سلاح يعد أخطر الأسلحة" (ك) .

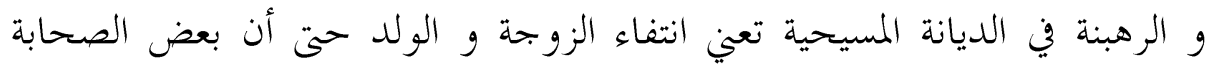

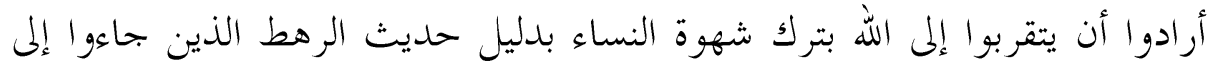

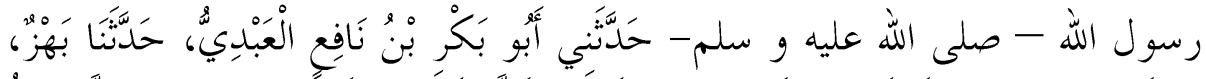

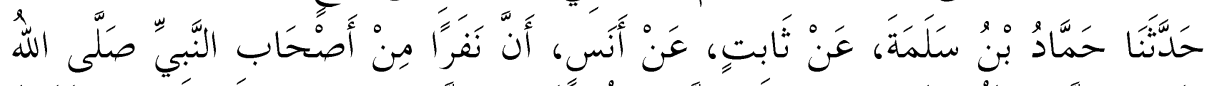

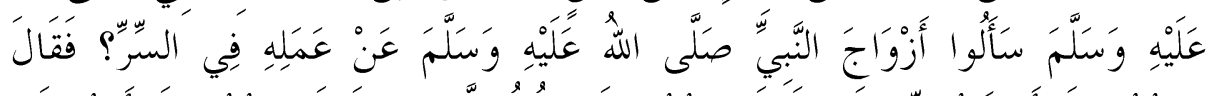

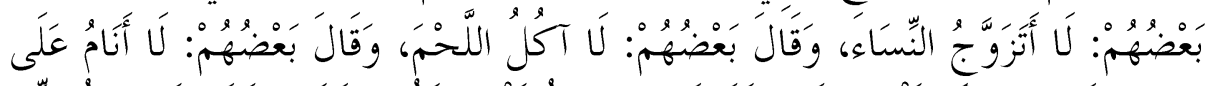

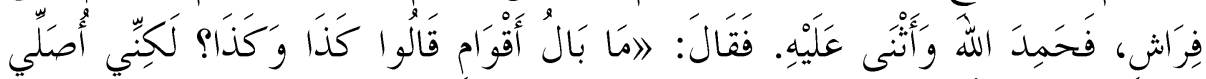

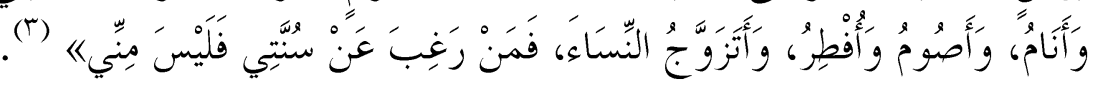

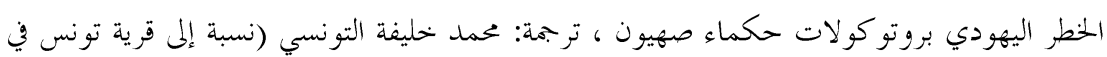

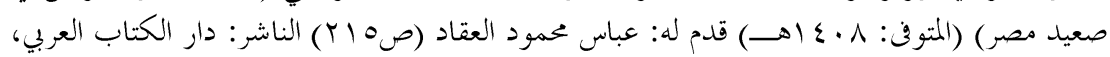

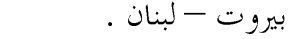

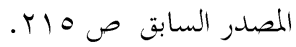

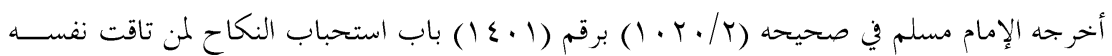

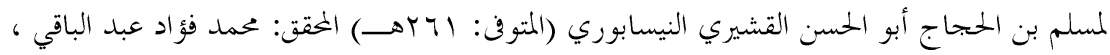

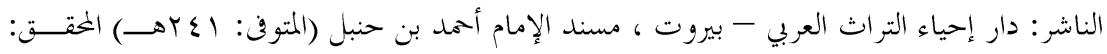

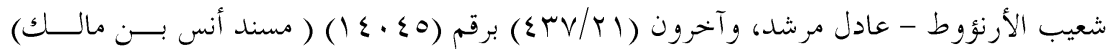

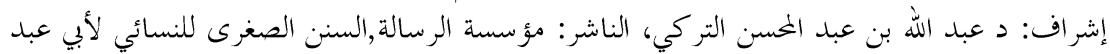

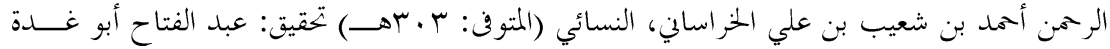

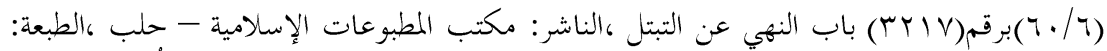

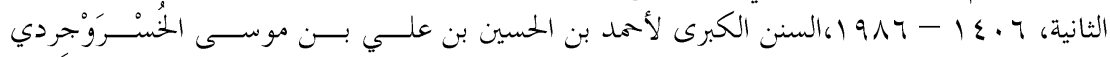

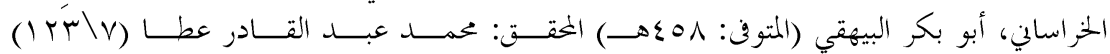

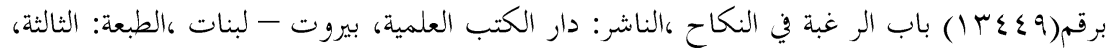




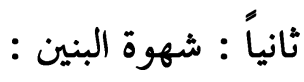

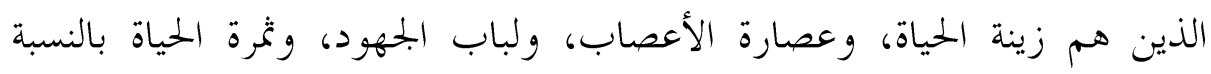

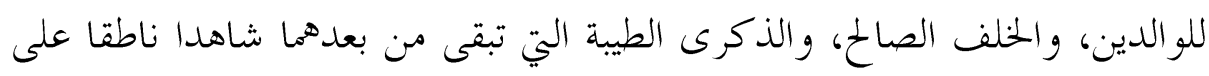

$$
\text { مرور هما بمو كب الأحياء. }
$$

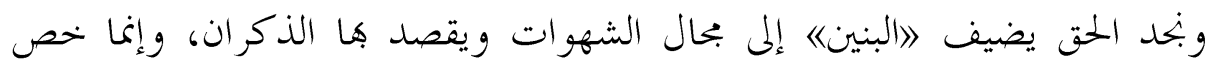

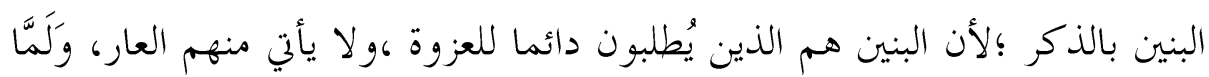

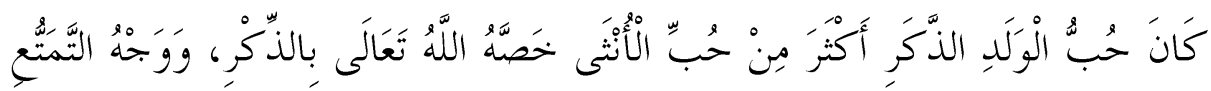

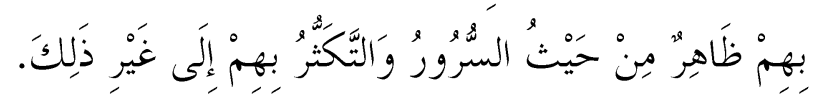

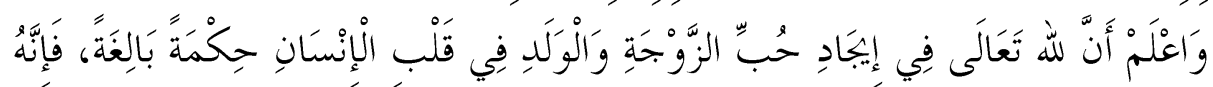

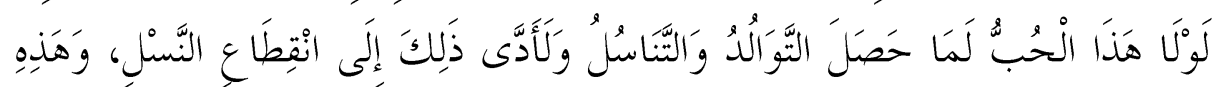

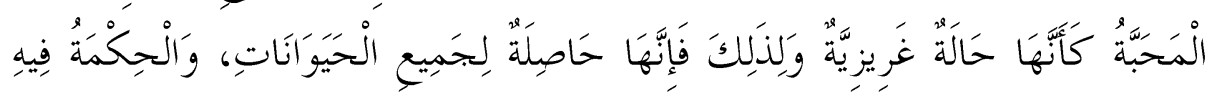
بَقَاء النَّنْلِ.

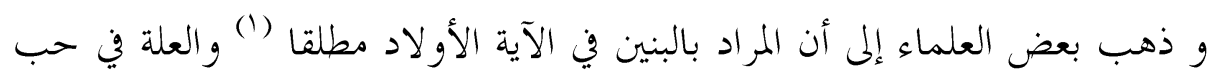

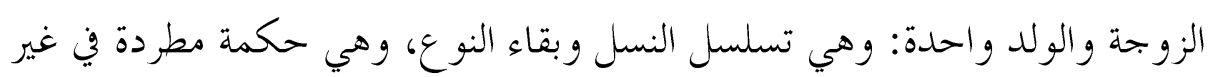

$$
\text { وحب البنين أقوى من حب البنان الإنات لأسباب كثيرة: }
$$

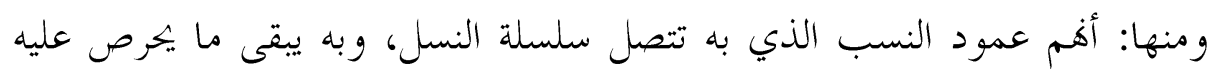
الإنسان من بقاء الذكر وحسن الأحدوثة بين الناس.

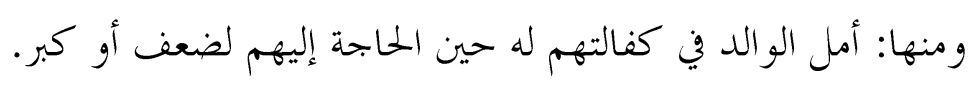

تفسير حدائق الروح والريحان في روابي علوم القرآن للشيخ العلامة محمد الأمين بن عبد الله الأرمسي الشي

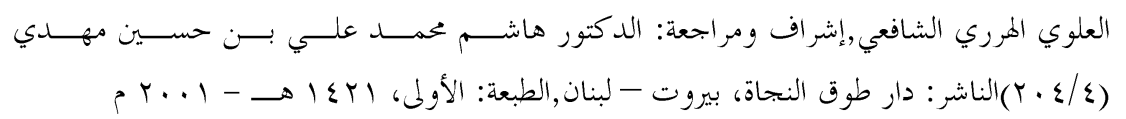




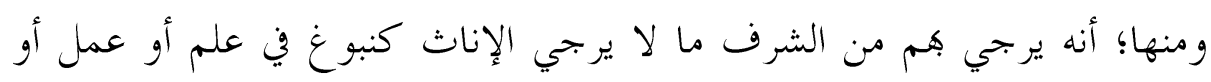

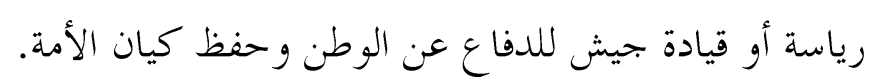

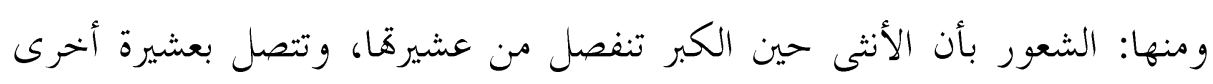

وثالثها: القناطير المقنطرة من الذهب والفضة: والعرب تريد بالقنطار المال الكثير

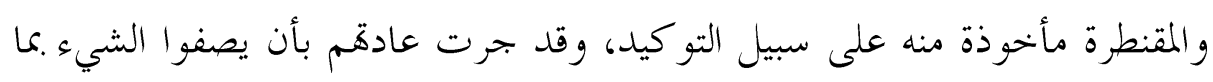

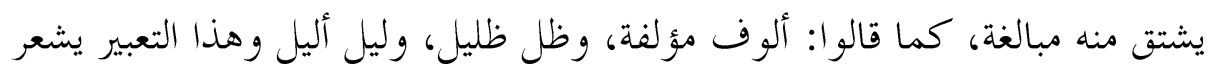

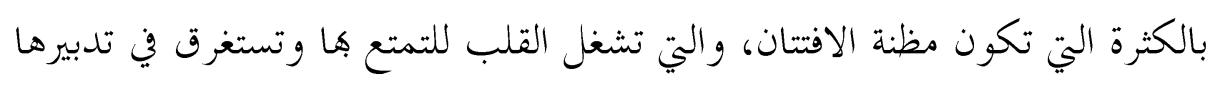

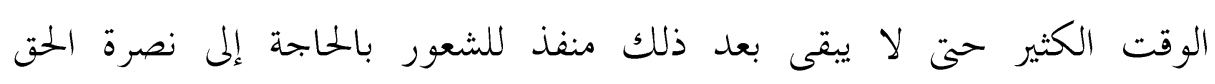
والاستعداد لأعمال الآخرة.

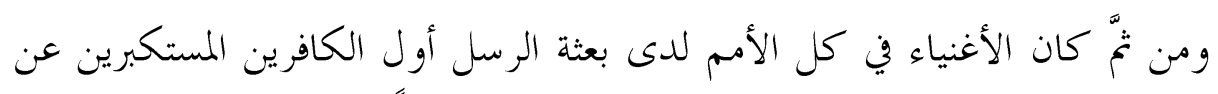

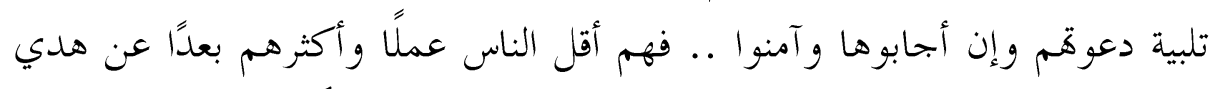

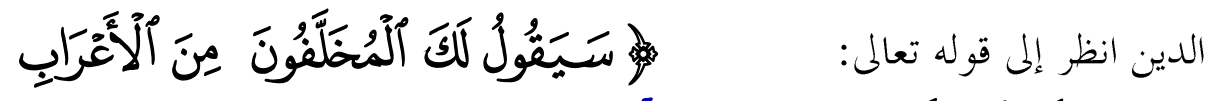

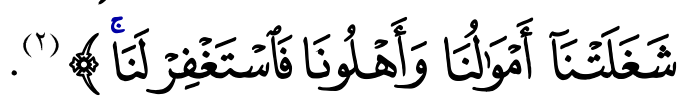

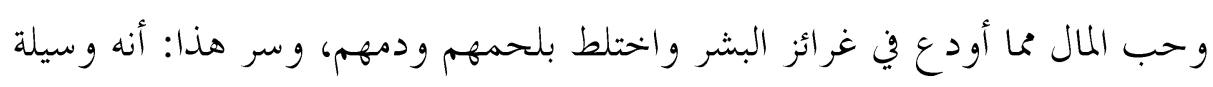

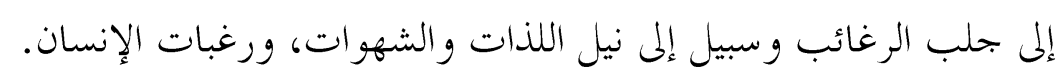

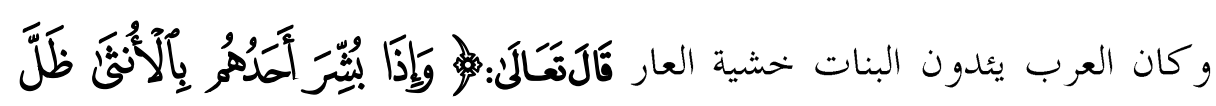

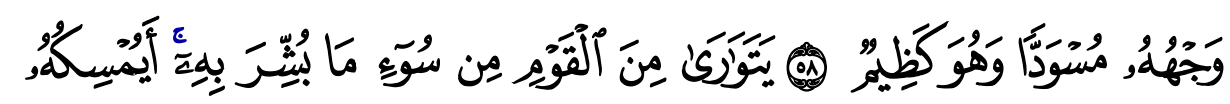

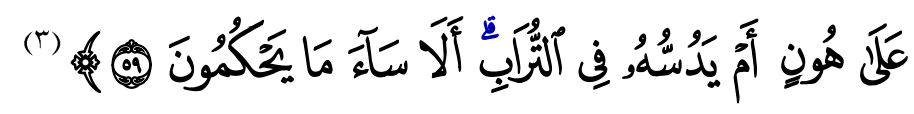

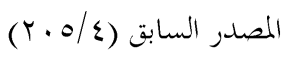

$$
\begin{aligned}
& \text { سورة الفتح :11 السانع/ه } \\
& \text { النحل: ه - - }
\end{aligned}
$$

rr. 
والخبوب لدى الرجل في الإنحاب حتى الآن هو إبحاب البنين، فالرغبة في إبحاب البنين غريزة جبلت عليها النفس الإنسانية .

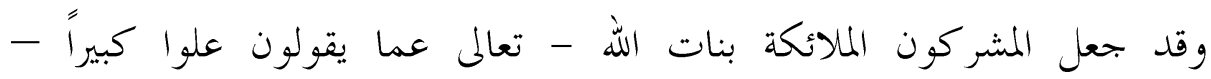

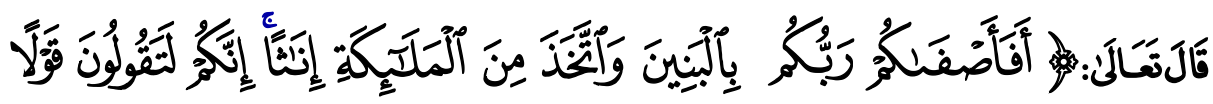

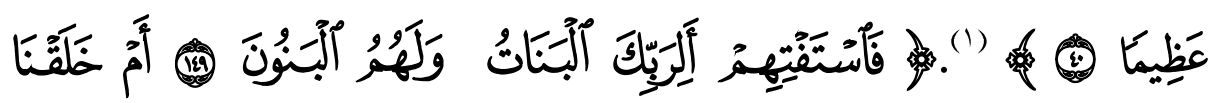

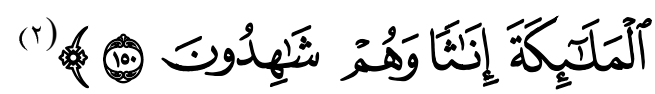

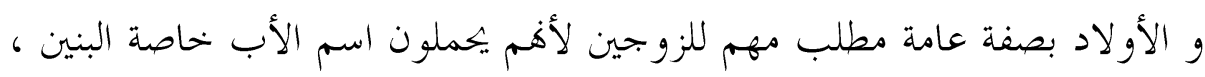

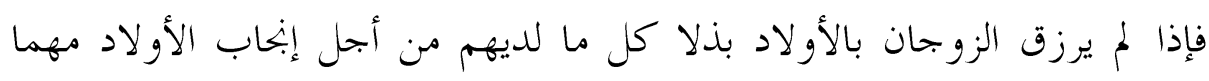

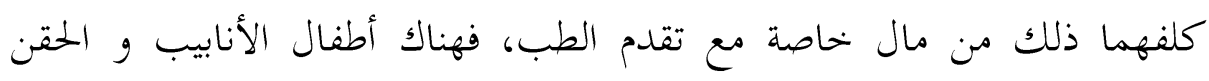

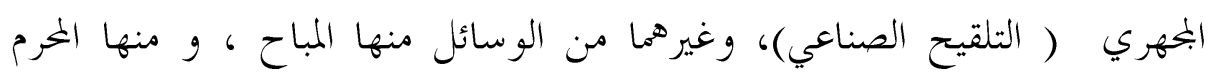

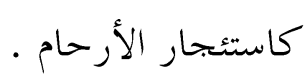

\section{موقف الإسلام من أطفال الأنابيب :}

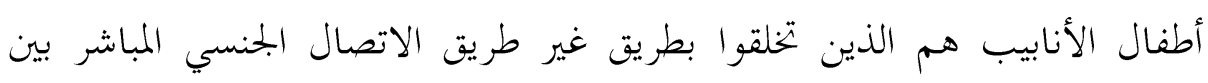

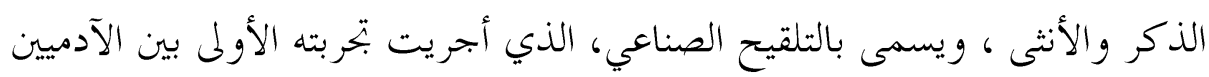

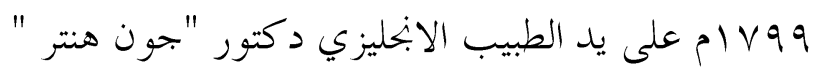

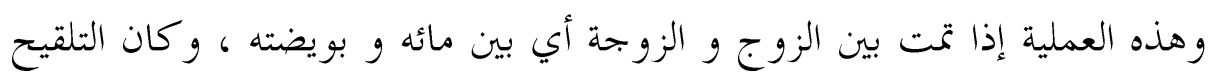

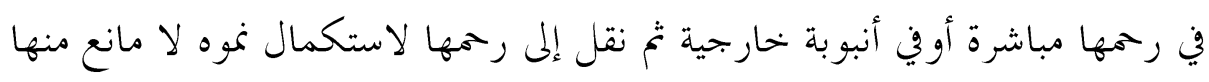

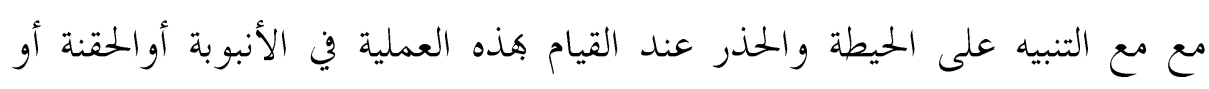

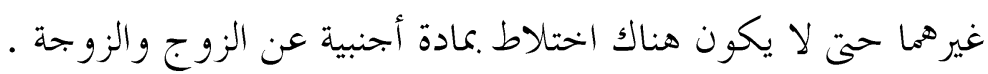

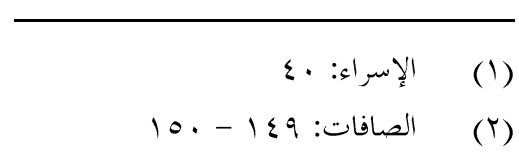


أما إذا كان التلقيح بغير ماء الزوج وبويضة الزوجة ، أو رحم آخر فهو حرام ؛لأنه

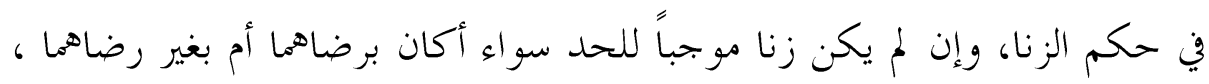

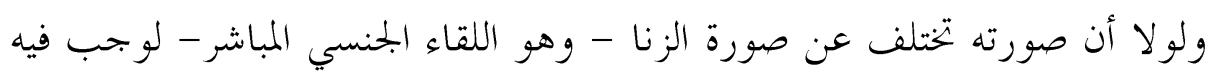

وذهب بعض العلماء إلى أنه إذا لم تكن هناك حاجة لهذا العمل فلا يجوز لأنه يتقدمه

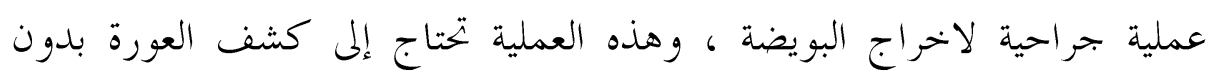
حاجة ثم إلى جراخة يخشى أن يكون منها نتائج ولو في المستقبل البعيد من تغير

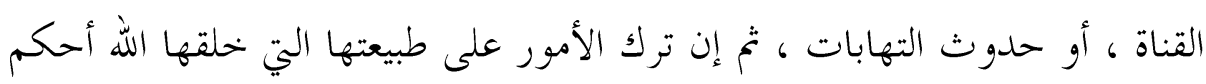

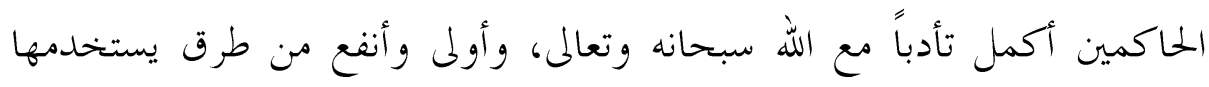

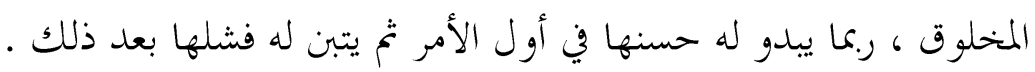

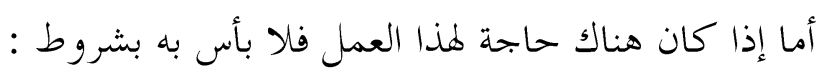

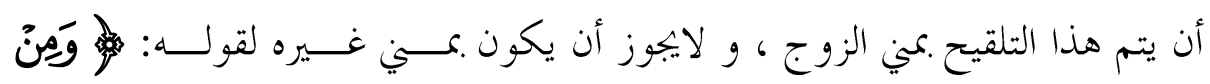

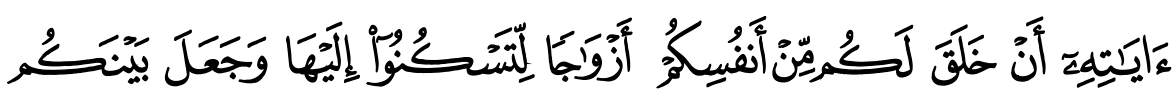

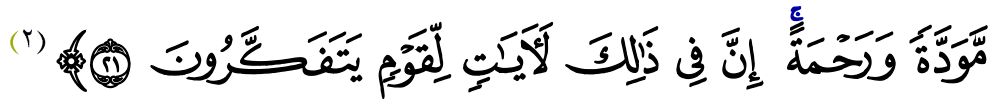
ا-أن تتم عملية إخراج المني من الرجل بطريق مباح بأن يكون ذلك عن

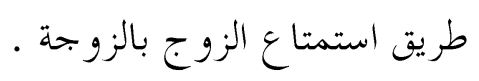

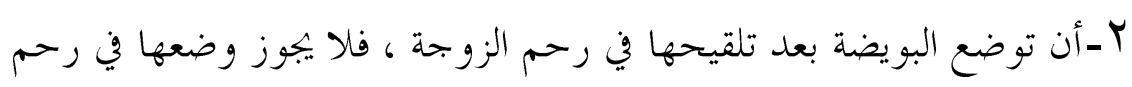

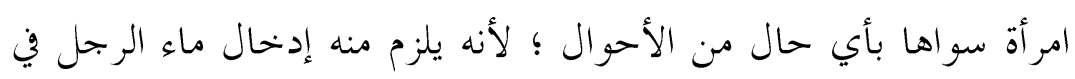

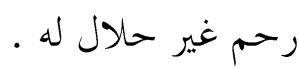

$$
\text { الأزتوى الشيخ عطية صقر عام لو99 19 ام ، راجع الأسرة تحت رعاية الإسلام - الجزء الأول , و و فتاوى }
$$




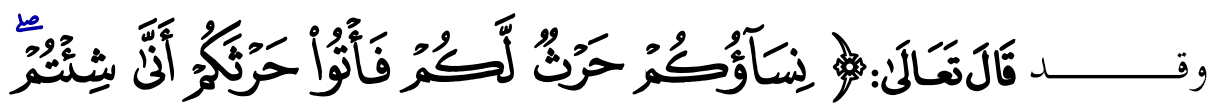

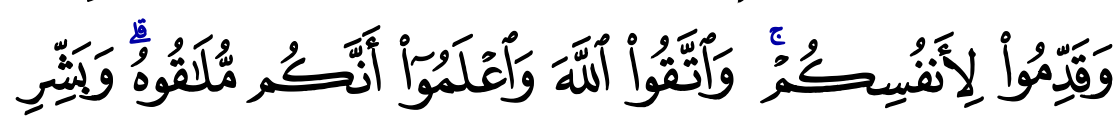

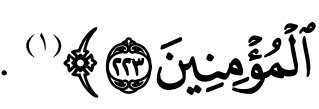

فخص الحرث بامر أة الرجل و هذا يقتضي أن تكون المرأة غير الزوجة غير

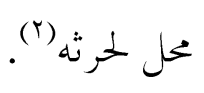

أما بالنسبة لمسألة استئجار الأرحام فقد قرربحمع الفقه الإسلامي المنعقد

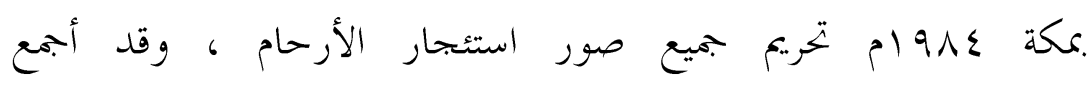

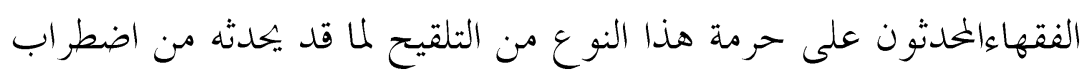

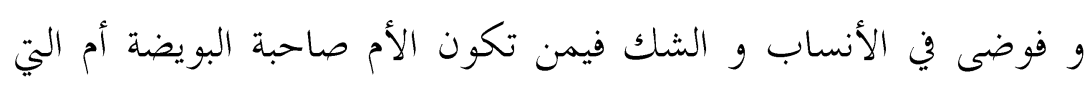

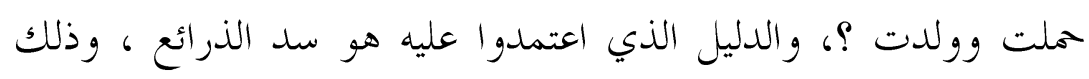

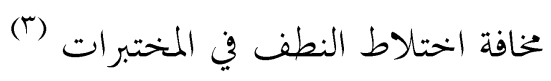

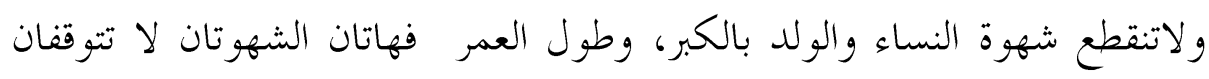

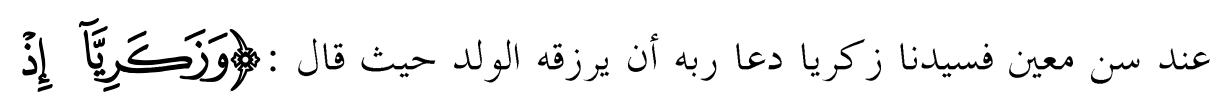

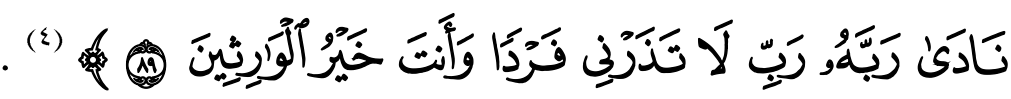

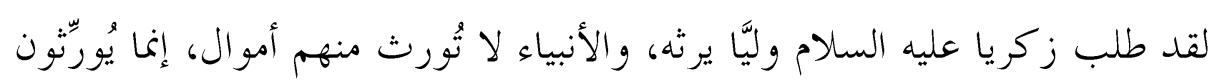

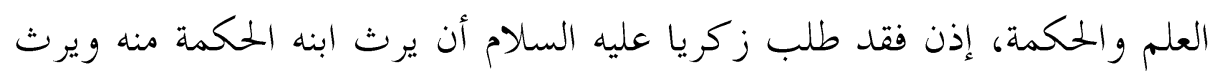

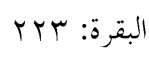

ينظر عمليات نقل و تأجير الأعضاء البشرية ، دراسة مقارنة بين الشريعة و القانون د/ جهاد محمـــود

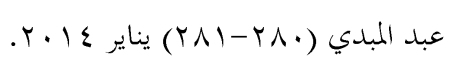

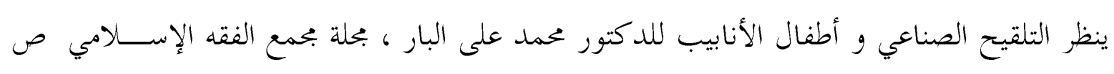

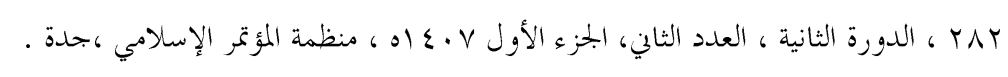

$$
\text { الأنبياء: } 91
$$




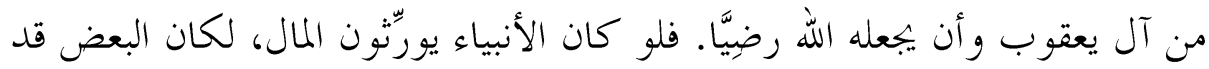

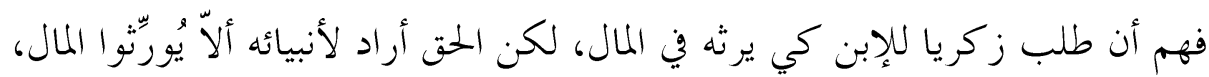

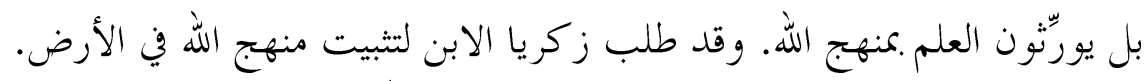

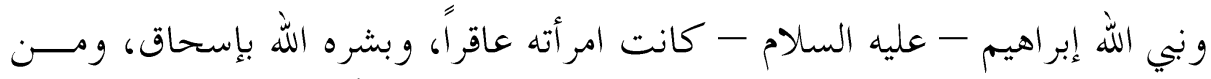

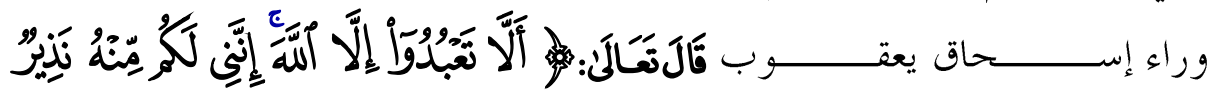

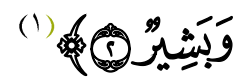
فالتعبير بلفظ البشرى يدل على أنه أمر محبب للنفس ، وهو مما يسر، ويفرح به الإنسان وإذا أبخب الإنسان البنات يظل قلبه معلقاً بإبحاب الذكور، بل قد يتزوج زوجة

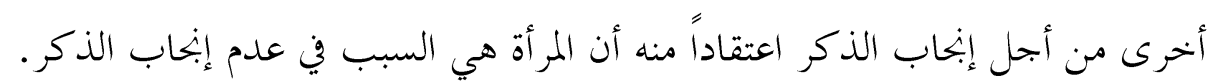

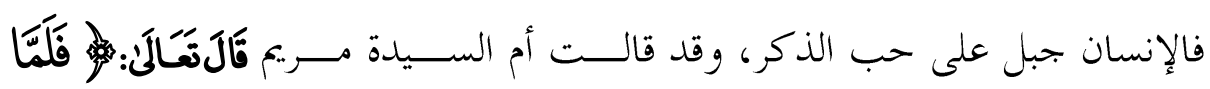

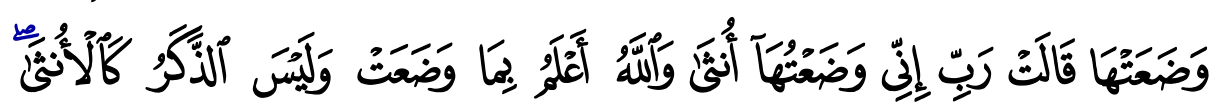

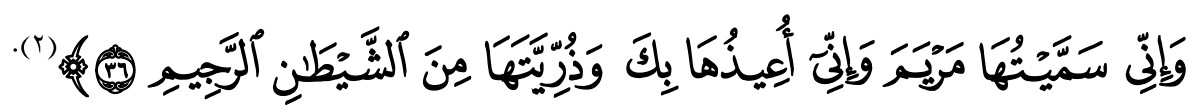
فالأنثى ليست كالذكر في تركيبها المحسمي، ولا في تركيبها النفسي، ومن ثم فلا بد أن تكون وظيفتها الحياتية تختلف عن وظيفة الذكر، ولا بد أن يترتب على ذلى ذلك الك

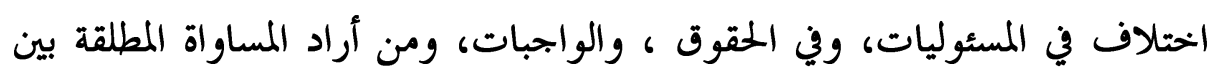
الرجال والنساء، فليسو بينهما في التركيب الجسمي والنفسى أولا ثم فليطالب.

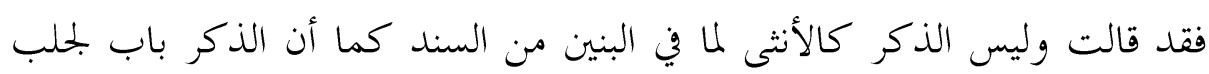

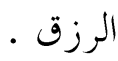

وفي المسيحية حينما أرادوا التقرب إلى الله كان ذلك بالبعد عن هاتين الشهوتين

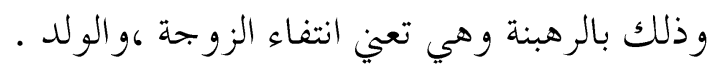

$$
\begin{aligned}
& \text { هود: VI } \\
& \text { آل عمران: }
\end{aligned}
$$


ثالثاً : شهوة المال :

وقد ذكرت الآية مظاهر المال متمثلة في (القناطير المقنطرة من الذهب و

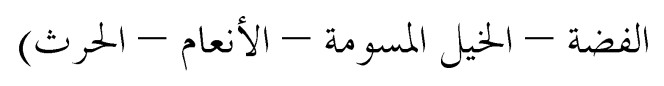

\section{ه القناطير المقنطرة من الذهب والفضة :}

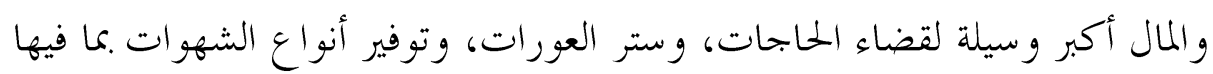

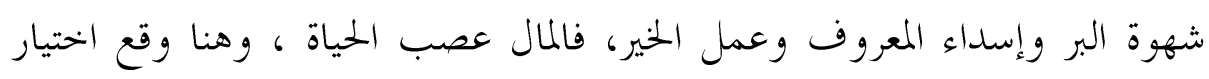

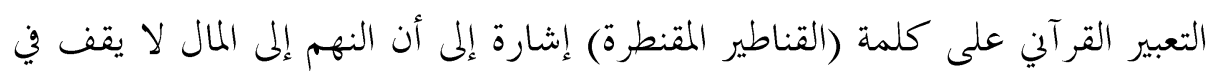

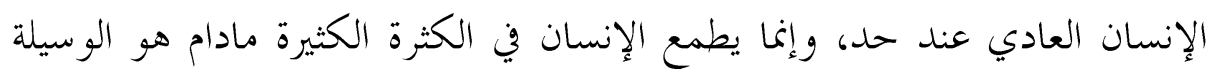

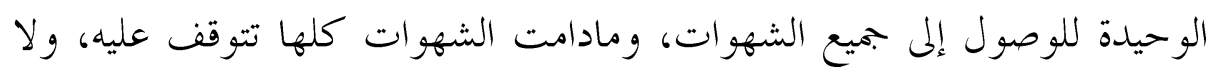

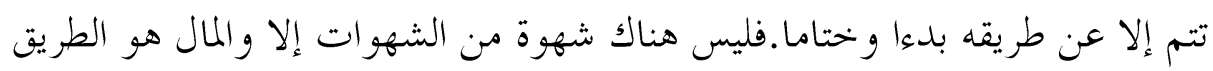
الموصل إليها، والقناطير هي جمع قنطار.

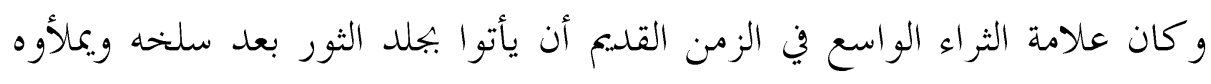

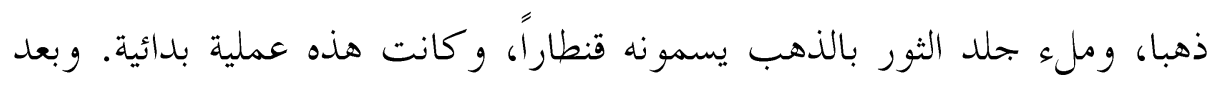

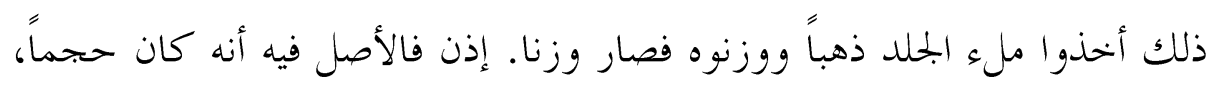

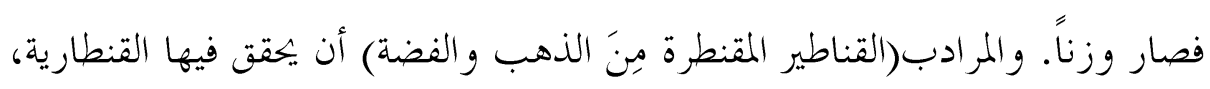

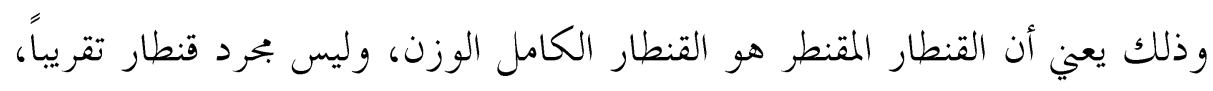

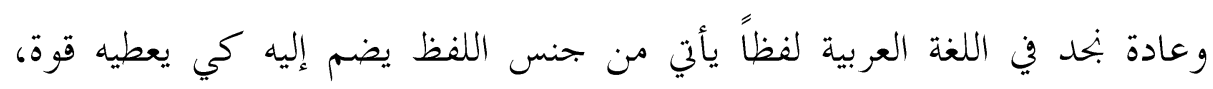

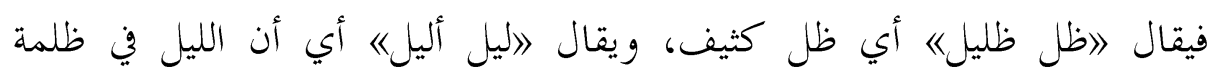
شديدة، وهي مبالغة في كثافة الظلام.

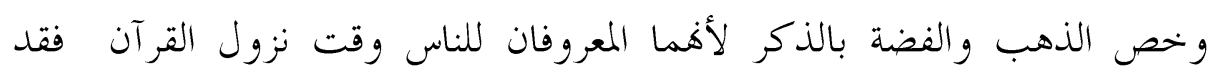

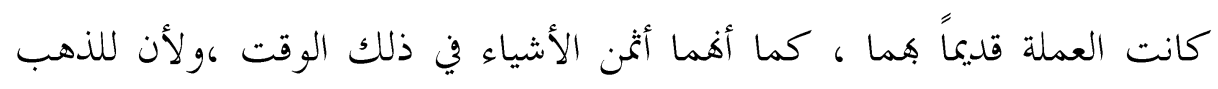

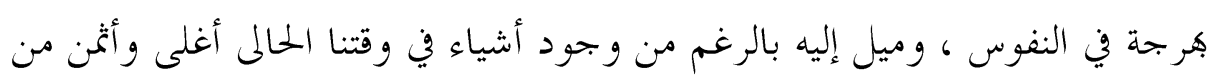


الذهب كالألماس ، والأحجار الكريمة ، وغيرها،وهذه الأشياء قليلة بالنسبة للذهب،

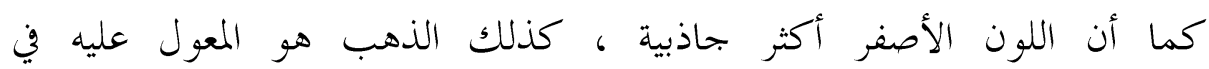

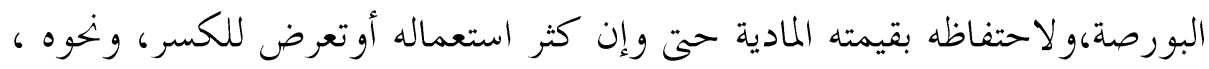

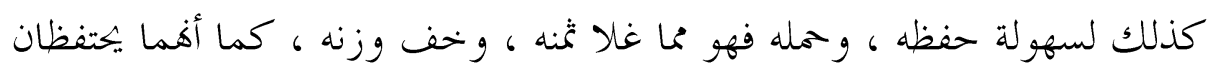

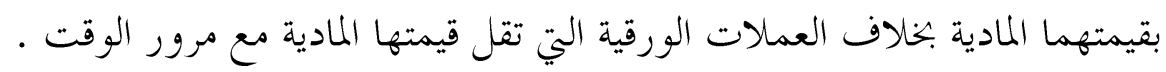

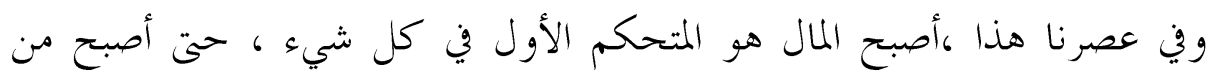
الشائع على ألسنة البعض أن من لديه مال يستطيع الوصول إلى أي شيء يطمع في الوصول إليه خاصة بعد انتشار الرشوة ، وضعف كثير من النفوس أمام شهوة المال. فأصبح المال المتحكم الأول في شتي مناحي الحياة المختلفة السياسية ، و الاقتصادية ، والاجتماعية ، و وغيرها. بل إن البعض أصبح لديه استعداد لارتكاب أي شيء مهما بلغت حرمته ، وجرمه

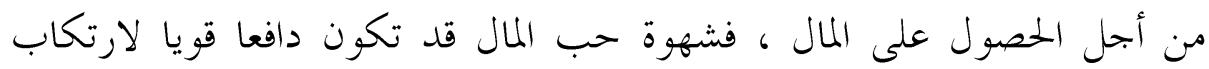

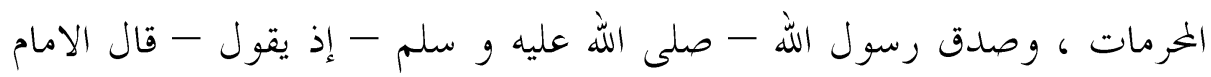

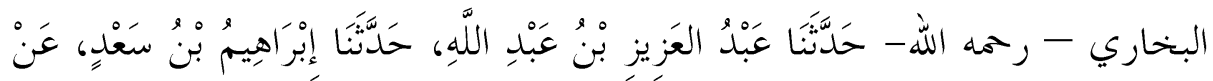

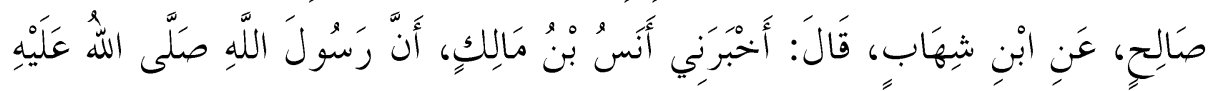

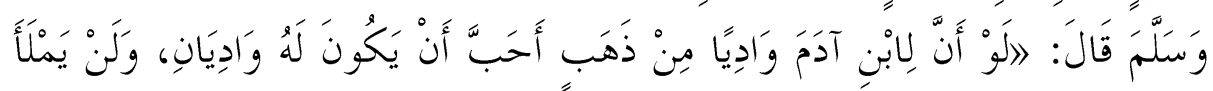

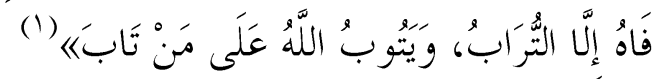

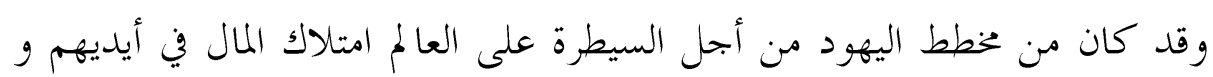
جعل باقي الشعوب تحت رحمتهم كما توضح برتوكولاهم ذلك فقد جاء فيها:"لزم

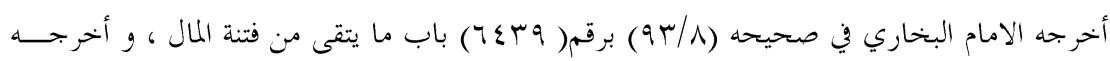

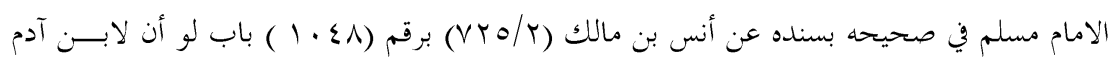

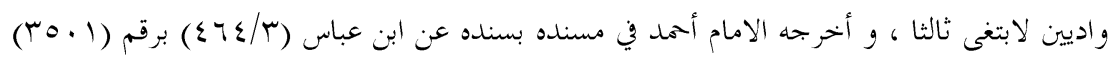

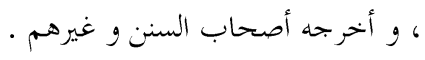


لغرضنا أن لا تحدث أي تغييرات أقليمية عقب الحروب، فبدون التعديلات الإقليمية ستتحول الحروب إلى سباق اقتصادي، وعندئذ تتبين الأمم تفوقنا في المساعدة التي سنقدمها، وان اطراد الأمور هكذا سيضع الجانبين كليهما تحت رحمة و كلائنا الدوليين ذوي ملايين العيون الذين يملكون وسائل غير محدودة على الإطلاق.

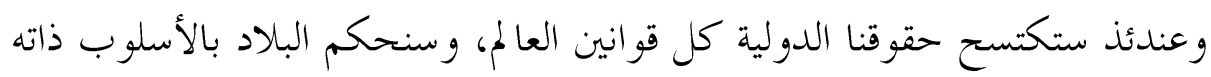
الذي تحكم به الحلكومات الفردية رعاياها.

و سنختار من بين العامة رؤساء اداريين ممن لهم ميول العبيد، ولن يكونوا مدربين

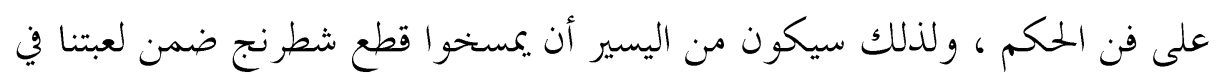

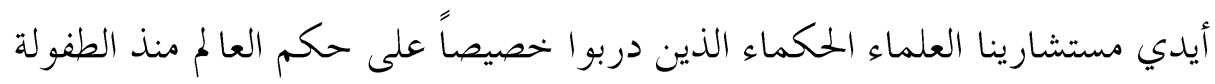

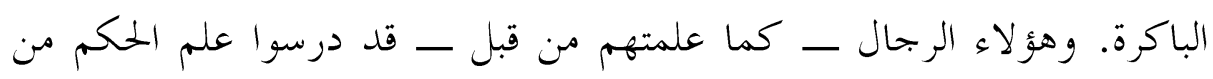
خططنا السياسية، ومن بتحبة التاريخ، ومن ملاحظة الأحداث الجارية. والأميون

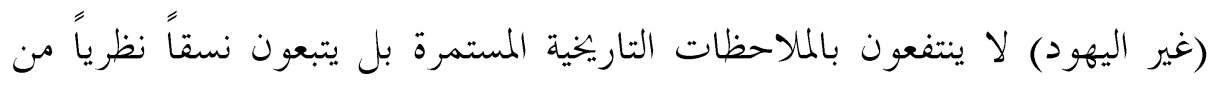

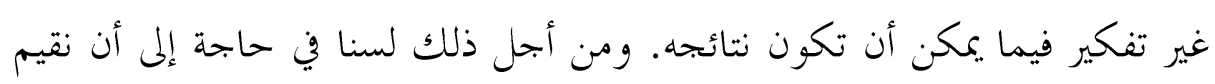
لالأميين وزناً.

دعوهم يتمتعوا ويفرحوا بأنفسهم حتى يلاقوا يومهم، أو دعوهم يعيشوا في

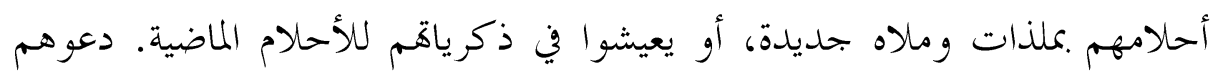

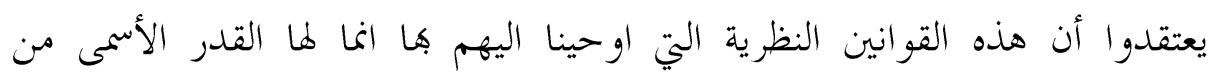
أجلهم. وبتقييد أنظارهم إلى هذا الموضوع، و.مساعدة صحافتنا نزيد ثقتهم العمياء

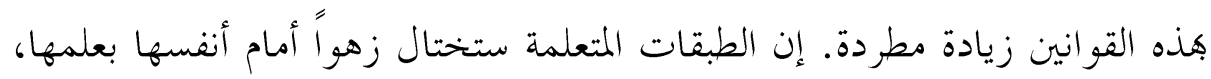
وستأحذ جزافاً في مزاولة المعرفة التي حصلتها من العلم الذي قدمه إليها و كلاؤنا رغبة في تر بية عقولنا حسب الاتجاه الذي توخيناه.

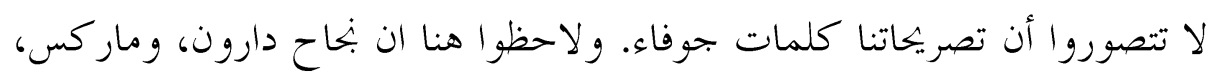

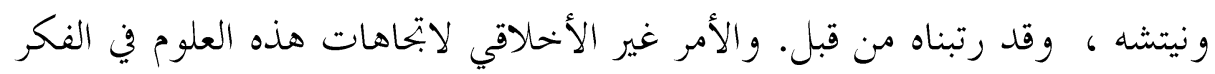


الأمي (غير اليهودي) سيكون واضحاً لنا على التأكيد. ولكي نتجنب ارتكاب

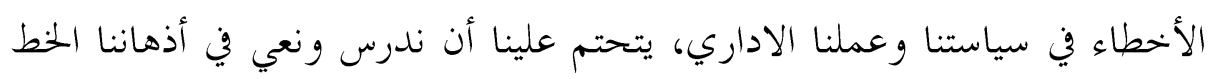

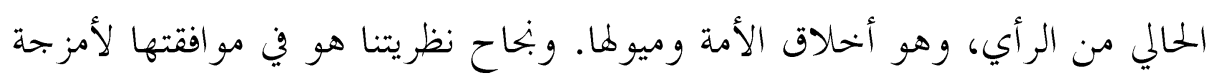

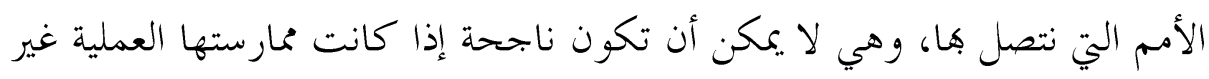

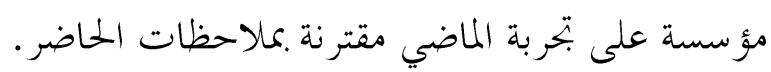

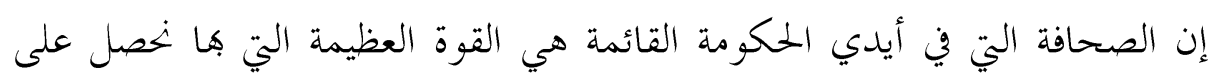

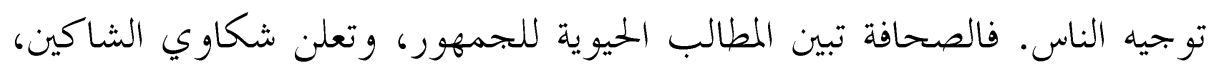

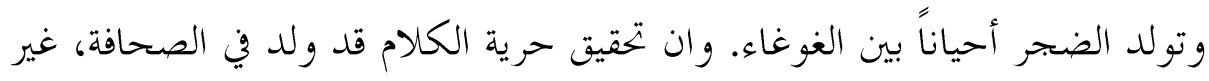

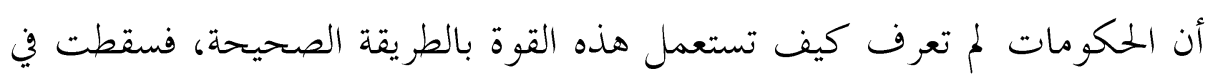

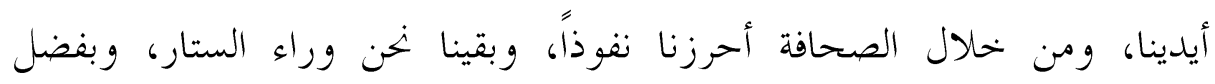

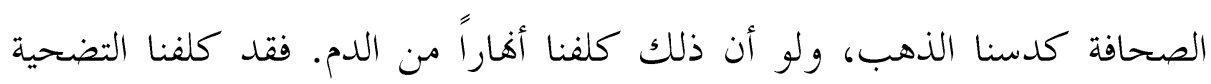
بكثير من جنسنا، ولكن كل تضحية من جانبنا تعادل آلافاً من الأمميين (غير اليهود) أمام اللة (1).

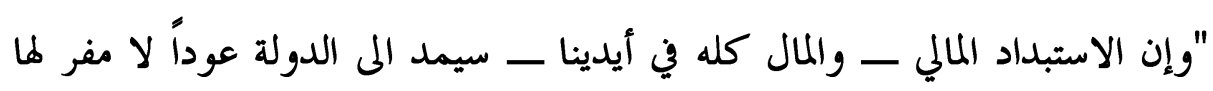

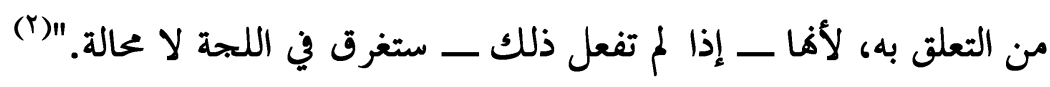

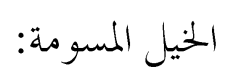

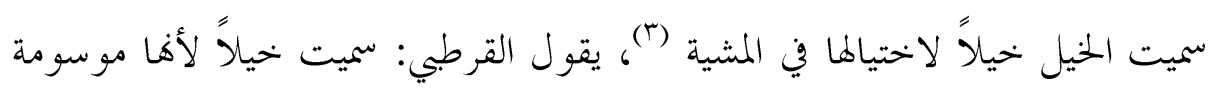

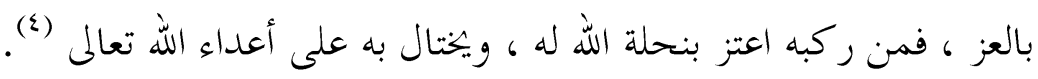

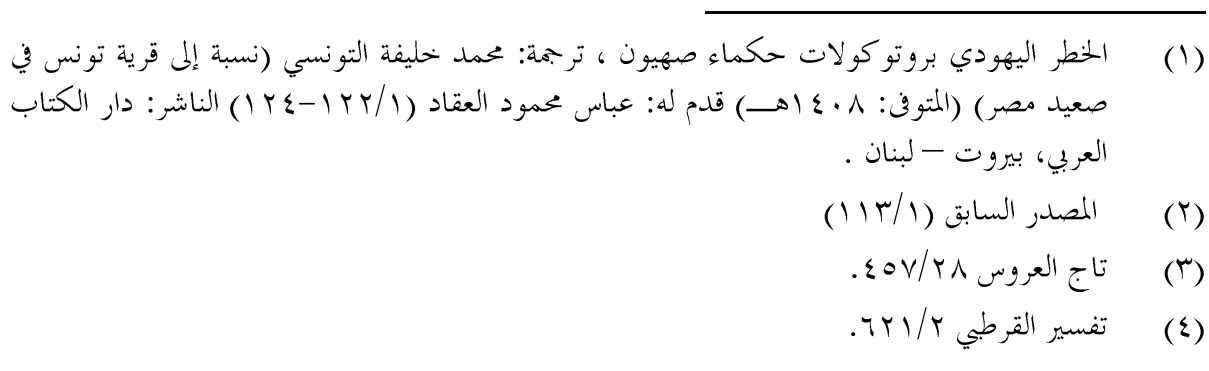

Irro 
و قد عرف لفظ الخيل بأسماء منها :

الفرس : وهو واحد الخيل ، والجمع أفراس ، وفروس الذكر والأنثى فيه سواء ،

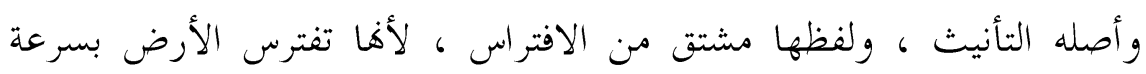

مشيها

الحصان : وهو الفحل من الخيل ، والجمع حصن ، مشتق من الحصانة لأنه

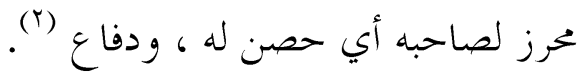

الجواد : و هو الفرس الجيد العدو ، سمي بذلك لأنه يبجود بجريه ، فيقال : قوم

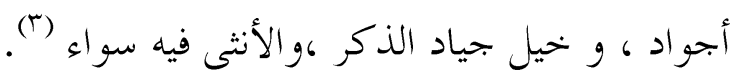

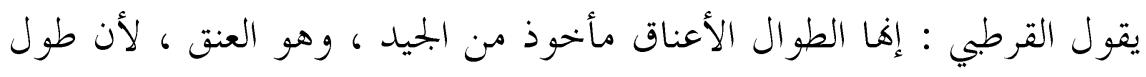

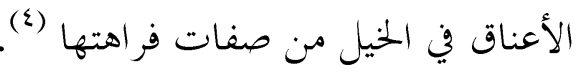

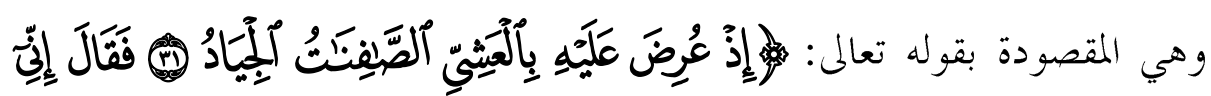

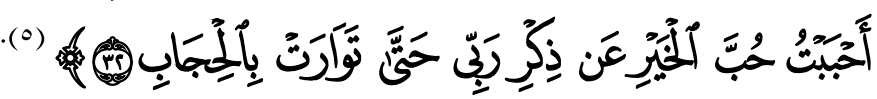

وللخيل سلالات كثيرة أهمها الخيول العربية ، وهي من أقدم السلالات لهات في العالم ،

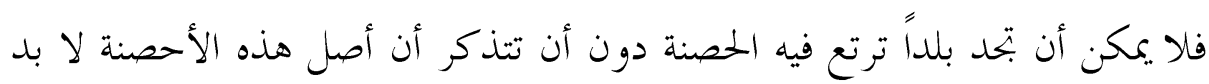
أن يكون فيها دم حصان عربي (ج).

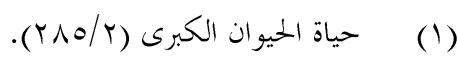

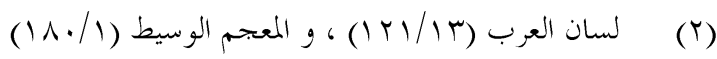

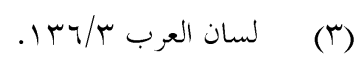

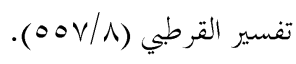

$$
\begin{aligned}
& \text { سورة ص: آr - Tr }
\end{aligned}
$$

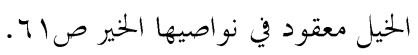


ويلحق بالخيل البغال و الحمير وقد جمع الله - عزو جل - بينهم في

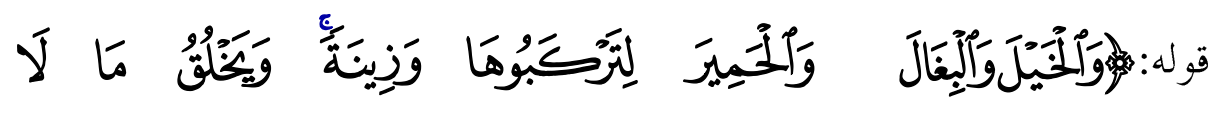
(1)

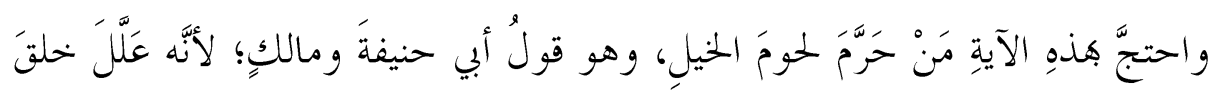

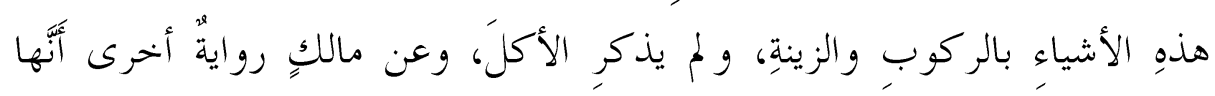

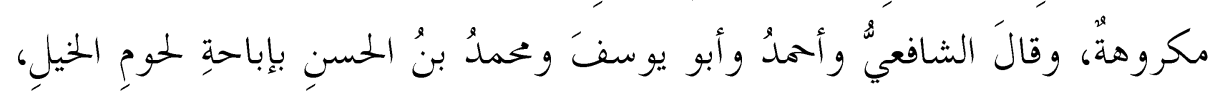

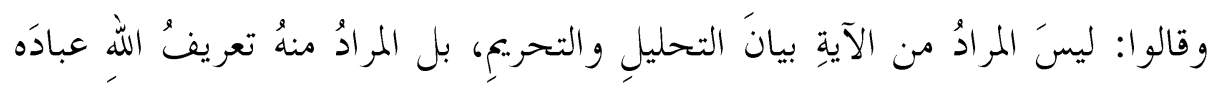

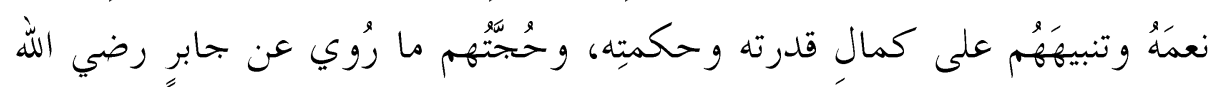

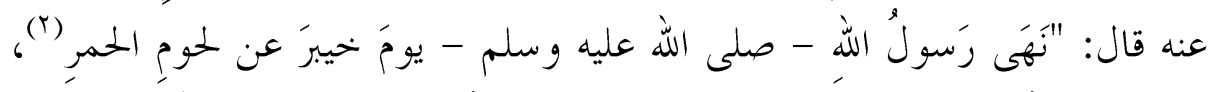

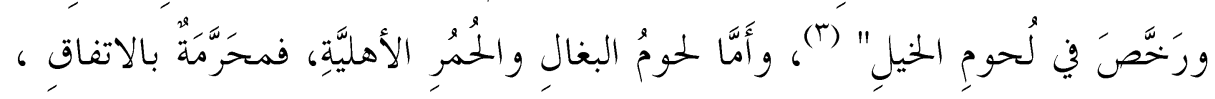

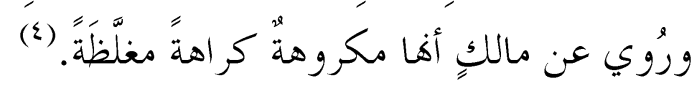

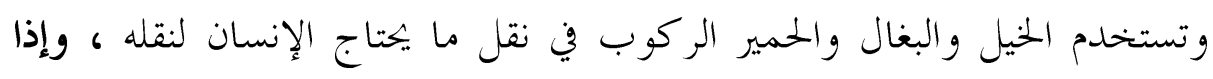

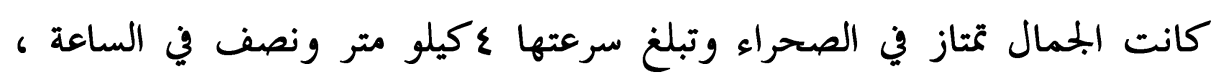
فكذلك البغال تمتاز في الجبال (o)

$$
\begin{aligned}
& \text { (1) } \\
& \text { يقصد الحمر الوحشية أما الحمر الأهلية فلحومها حرام . مالمان. }
\end{aligned}
$$

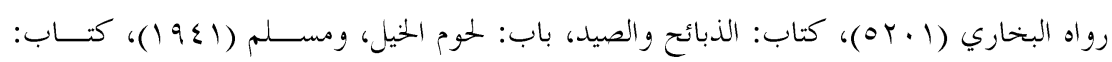

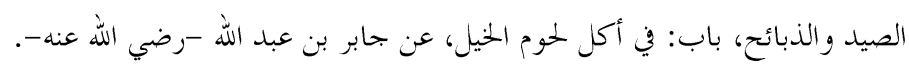

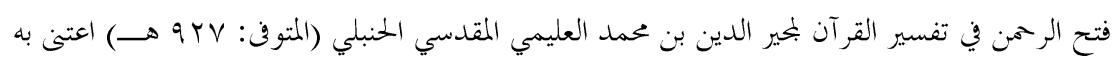

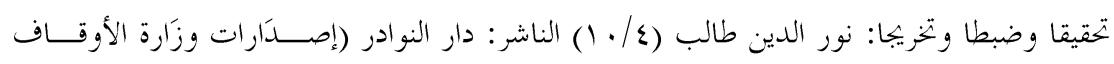

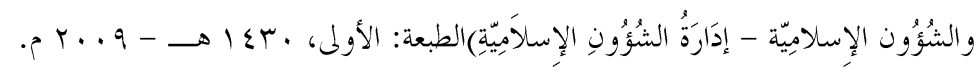

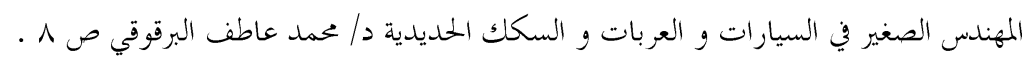


و يستطيع الحيل أن يحمل ربع وزنه ، كما أن لديه القدرة على العدو، والجري

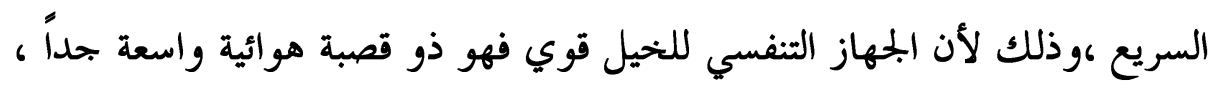
وقفص صدري واسع جداً ، يعينه على استنشاق أكبر كمية من الأكسجين لتعينه هذه الكمية على الجري الطويل (1)

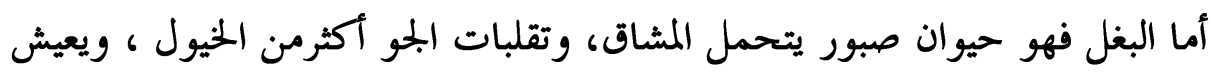

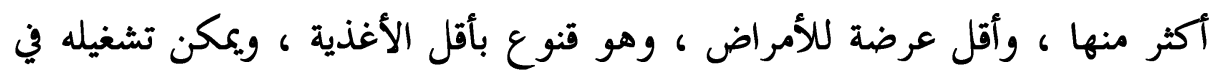

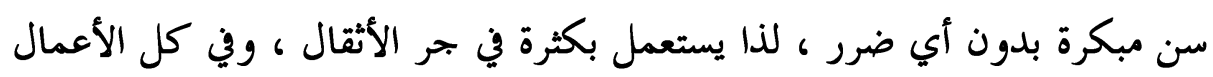

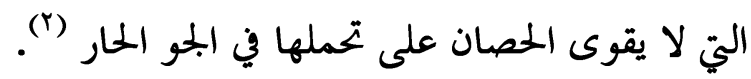

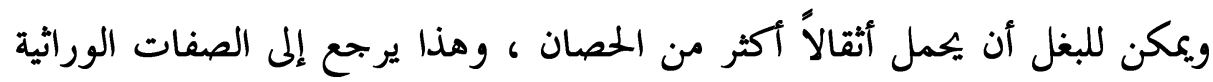

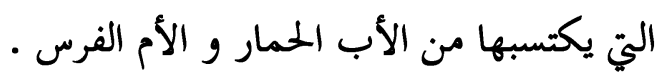

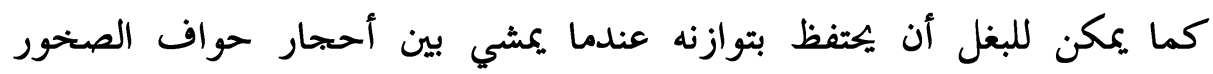

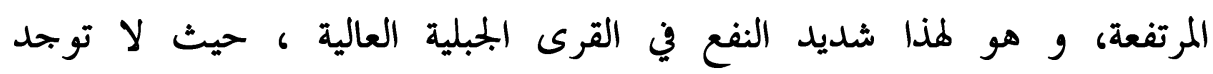

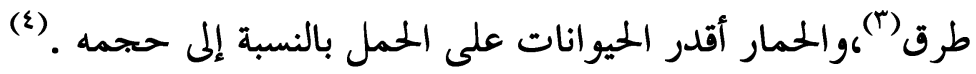

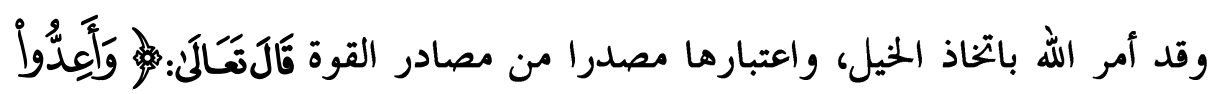

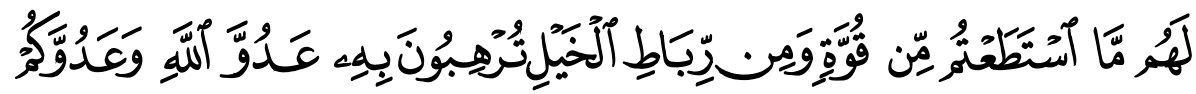

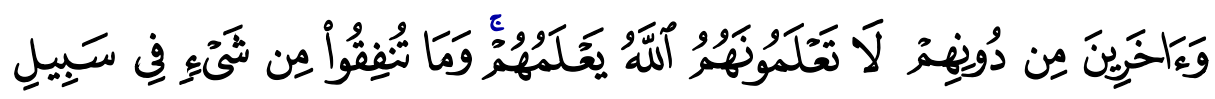

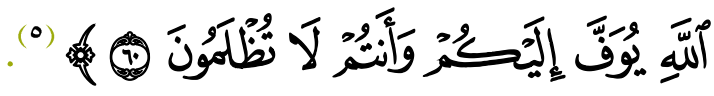

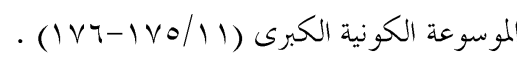

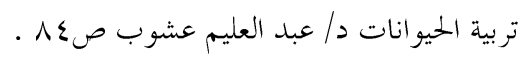

$$
\begin{aligned}
& \text { الموسوعة الكونية الكبرى (1// . . ب) . } \\
& \text { صدق البيان في طب الحيوان ص ع ب. } \\
& \text { الأنفال: .7 }
\end{aligned}
$$


فالخيل عند العرب كانت أعظم عددهم ، وأنفذ آلات ظفرهم .عقصدهم ؛ لأن

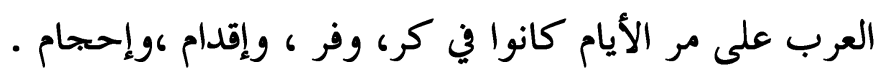

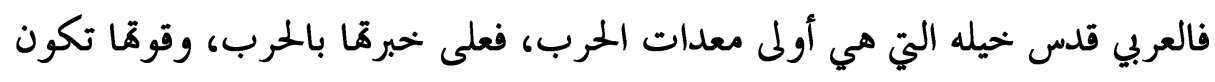

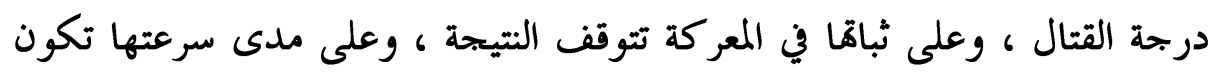

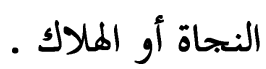

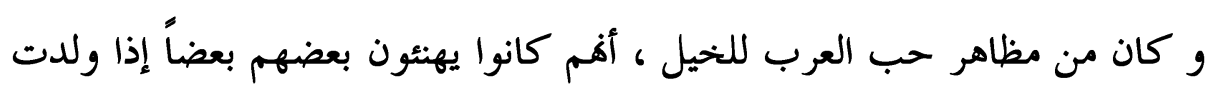

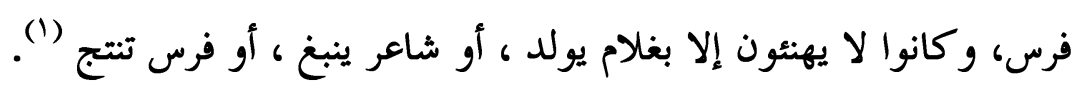
وهذا يفسر حرص العرب على حفظ أنساب الخيل حفظ أنساهم .

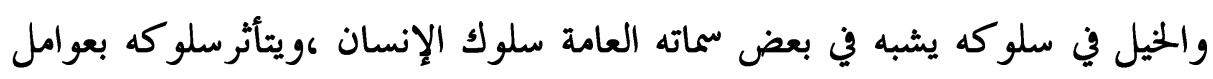

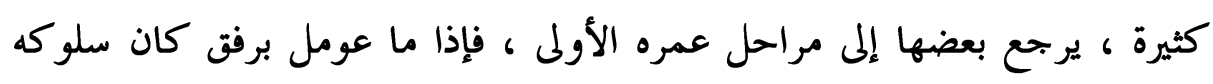

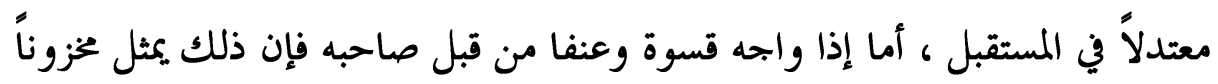
سيئاً لديه .

ومن الحيل ما يعرف صاحبه ، ولا يمكن غيره من الركوب عليه ؛ لذا نرى معظم

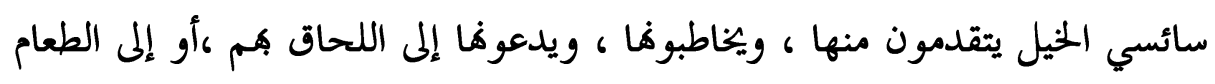
و الشراب ، فهو لا يسلم قيادته إلا لمن يعرفون شؤونه

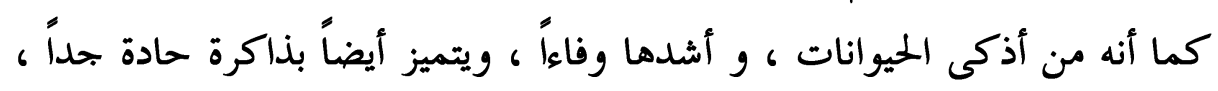

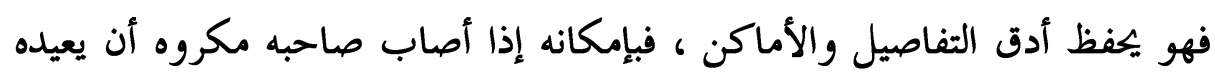
إلى البيت بذاكرته . ومن طبع الفرس أيضاً الزهو والخيلاء بنفسه ، وعلو الممة .

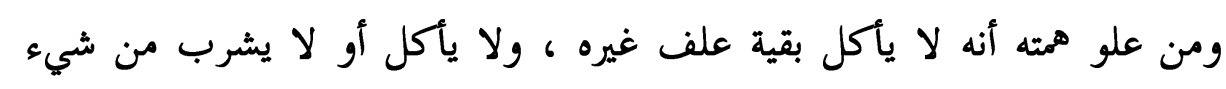
مشكوك في نقائه (r) معله 
وقد بين الله تعالى أنه جعل الخيل والبغال والحمير زينة ، والزينة هي شيء زائد على الحي

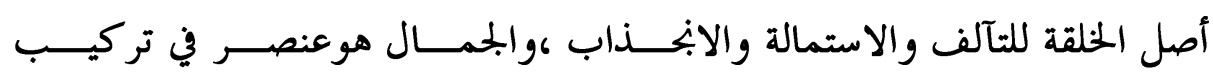

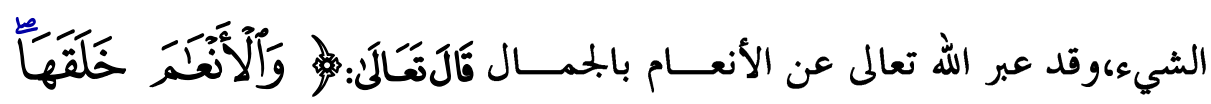

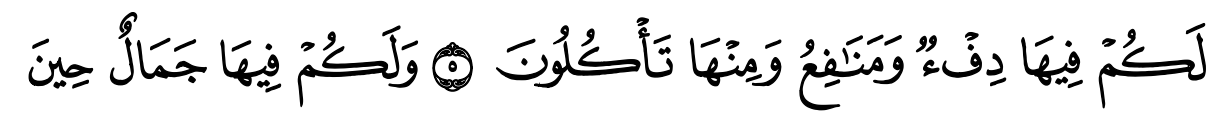

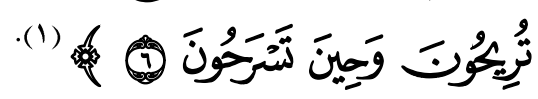

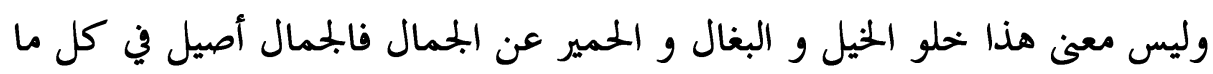

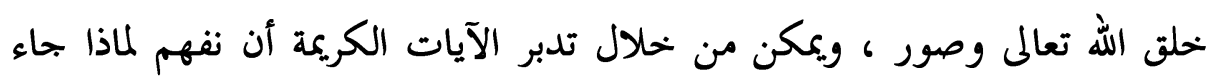

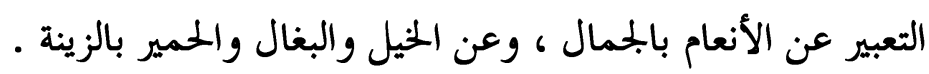

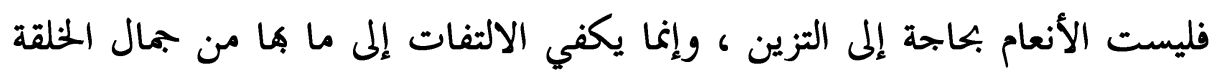

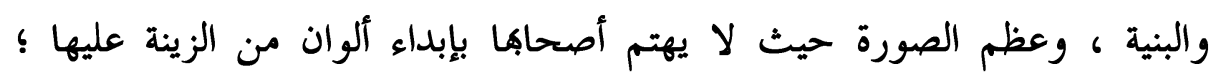

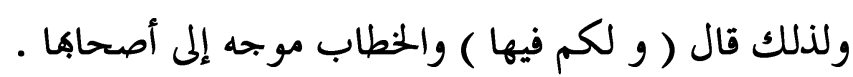

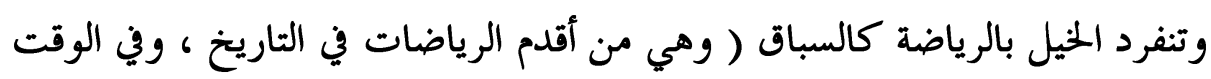

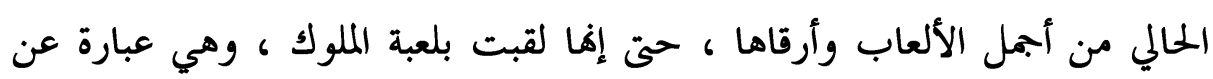

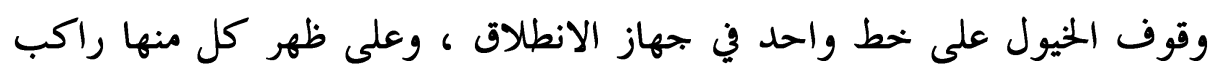

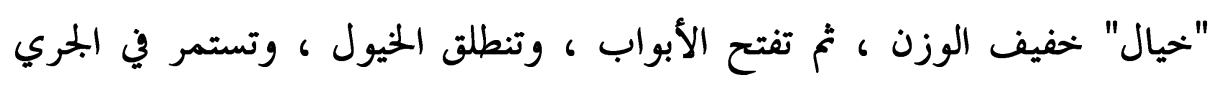
بأقصى سرعتها ، والذي يصل منها إلى خط النهاية أولاً هو الفائز ).

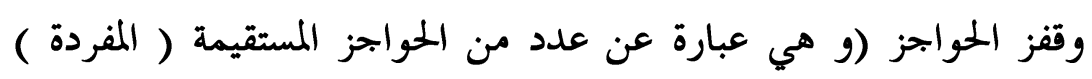

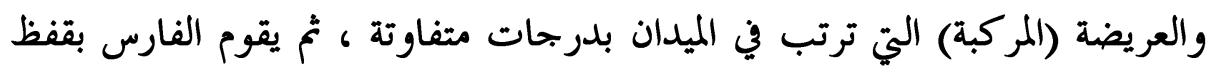

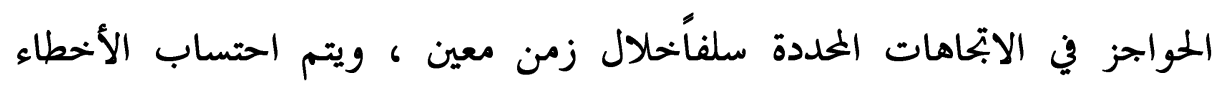

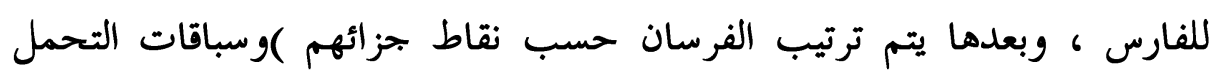

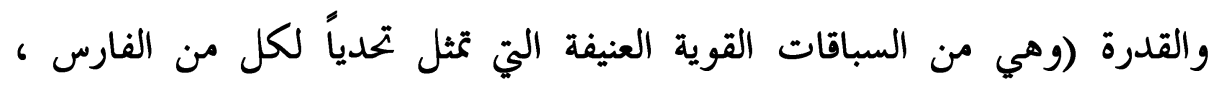


والحصان ، ومقدرة كل منهما على الصمود حت فاية السباق ، وتتتلف طول

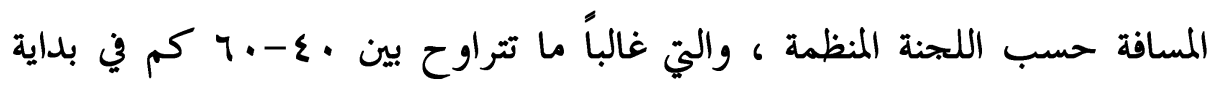

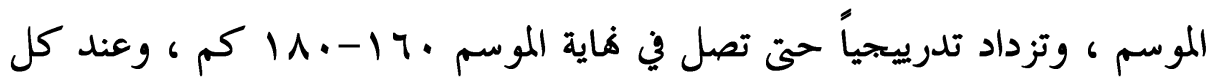

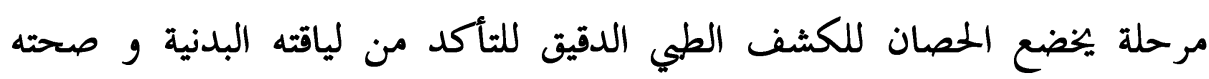
(العامة) (1)

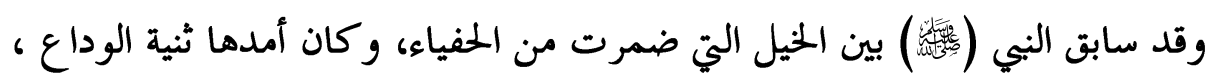

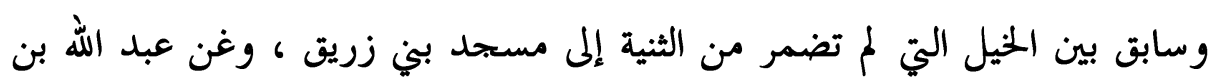

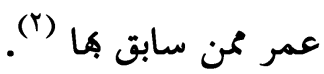

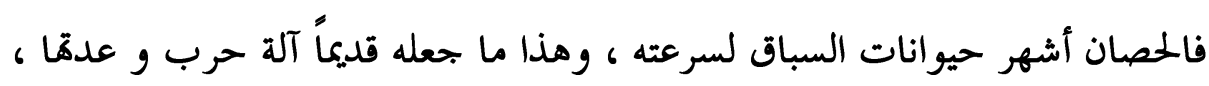

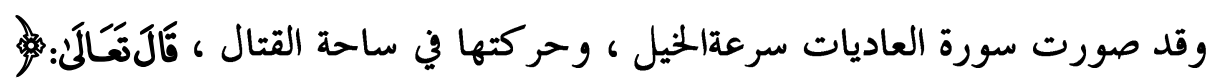

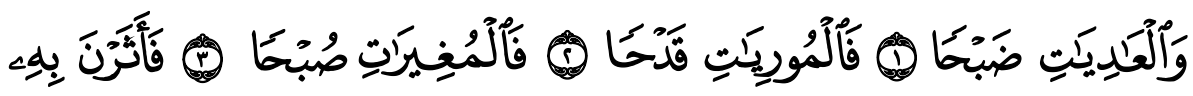
نَقْعَا أقسم تعالى بالعاديات ،وهي الخيول التي تعدو و بتري بسرعة ، وتضبح ضبحاً أ ي

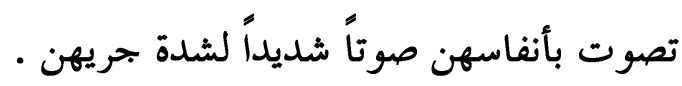

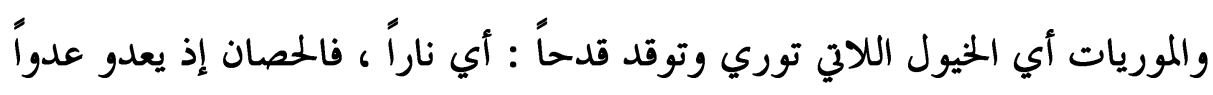

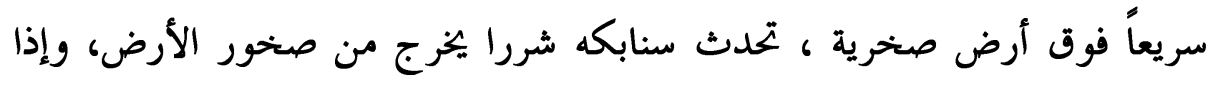

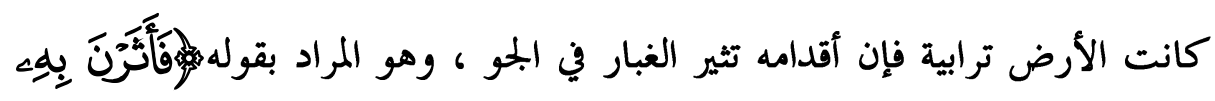

نََّّْا

$$
\begin{aligned}
& \text { الخيل معقود في نواصيها الخير ، ص ع T ا-1YN| . }
\end{aligned}
$$

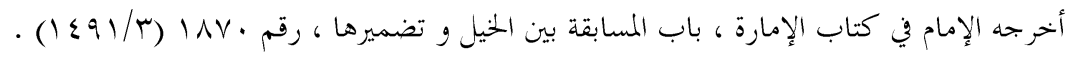

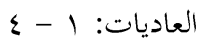

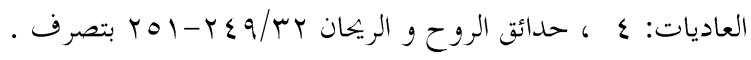


وتستخدم الخيل خاصة صغارها في التسلية والترفيه كذلك صغار البغال والحمير وهذا في حدائق الحيوان ، كما يستخدموا خارجها في السياحة والعروض المسرحية ، فهي مادة قيمة للترفيه عن الصغار والكبار •

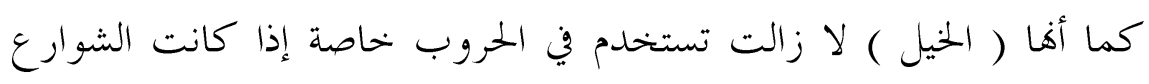
ضيقة .

ولحوم الخيل حلال قال الإمام القرطبي :" و الصحيح الذي يدل عليه النظر والحبر جواز أكل لحوم الخيل "فعن أسماء بنت أبي بكر الصديق - رضي الله الله

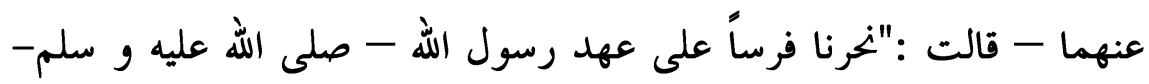
فأكلناه "(1) والذين تعودوا أكله يقولون إنه لذيذ حال كونه موافقاً للصحة ، والأوربيون يأكلونه ، ويباع في بحازر مخصوصة في فرنسا ، والنمسا ، وغيرها (r).

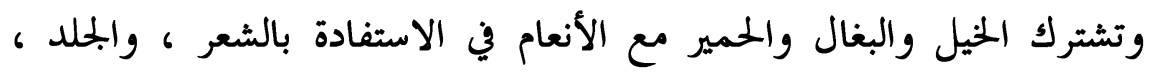

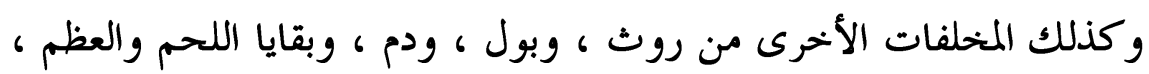

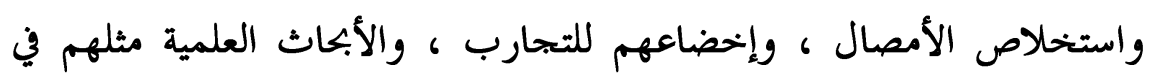
ذلك مثل سائر الأنعام مع الأحذ في الاعتبار اختلاف أوجه الاستعمال

$$
\text { باختلاف الحل والحرمة . ماند }
$$

فمثلاً تدخل مخلفات الأنعام بالإضافة إلى الخيل والبغال والحمير، بل الحيل الحيوان

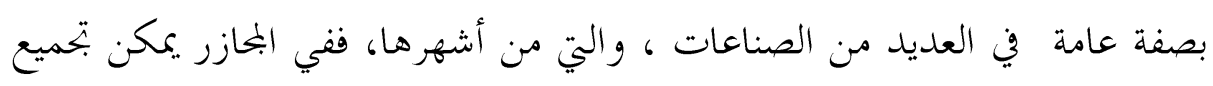

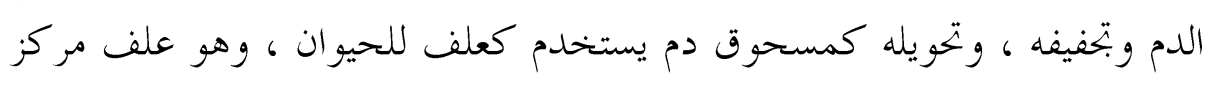

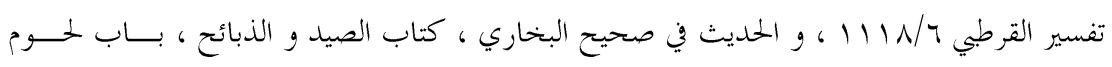

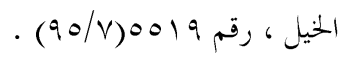

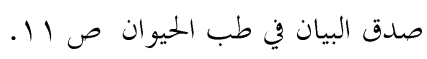


ذو محتوى عال من البروتين تصل نسبته ، ^\% ، وفي تكرير السكر، وفي صناعة

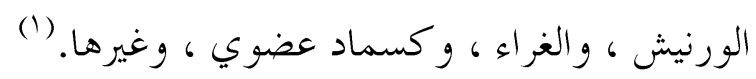

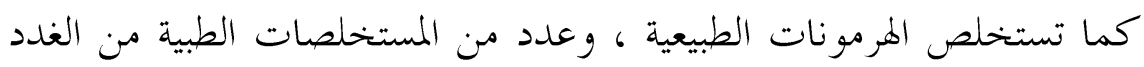

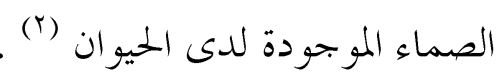

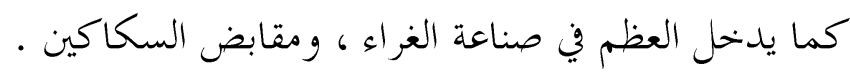

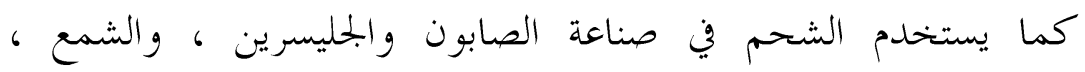

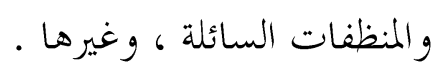

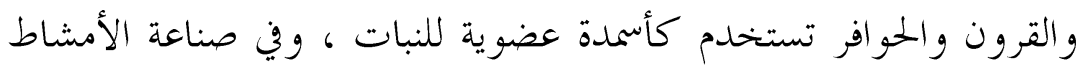

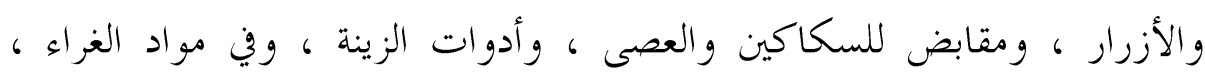
و الصنفرة ، وغيره (r) كذلك روث الأنعام ( الجزء غير المهضوم من غذاء الحيوان ) وأبواها

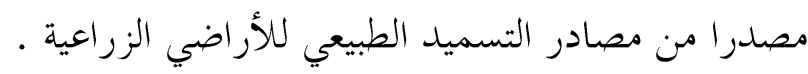

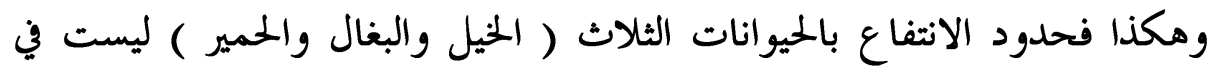

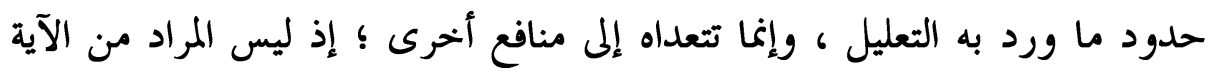
حصر أوجه الانتفاع بل المراد التنبيه إلى أهمها .

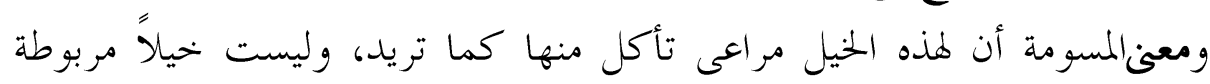

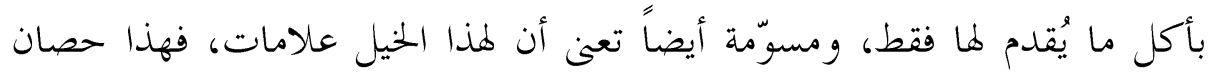

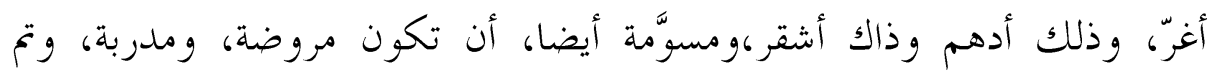

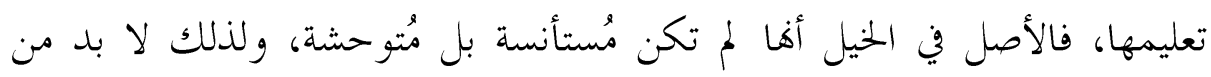

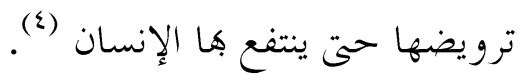

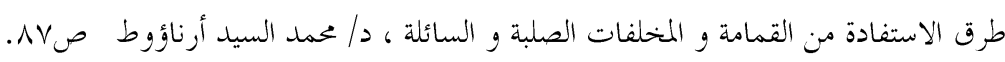

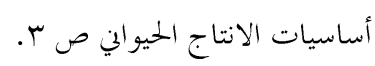

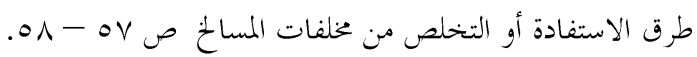

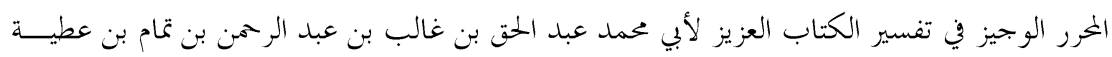

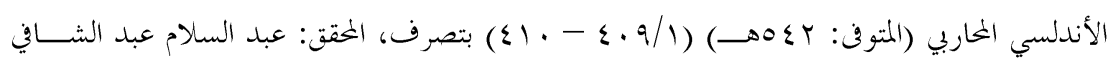

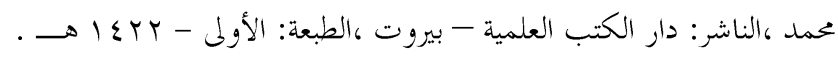


اسم الأنعام مستمد من "النعمة " وهي الحالة الحسنة، والصنيعة، وما أنعم به من

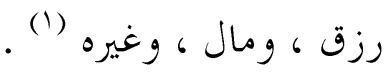

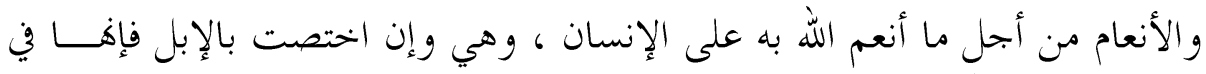

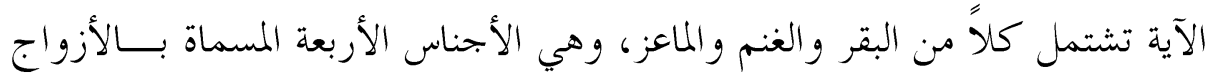

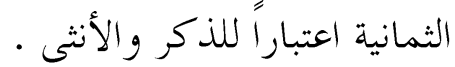

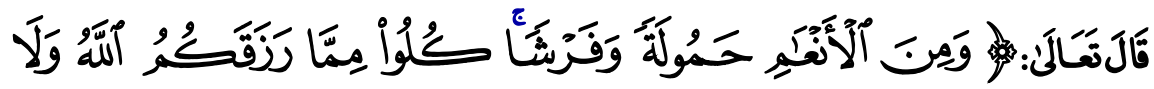

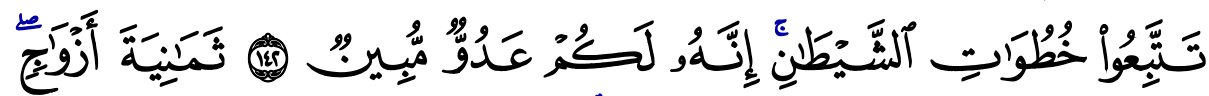

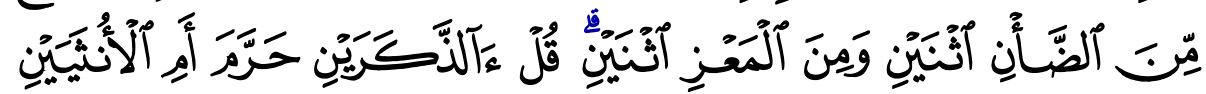

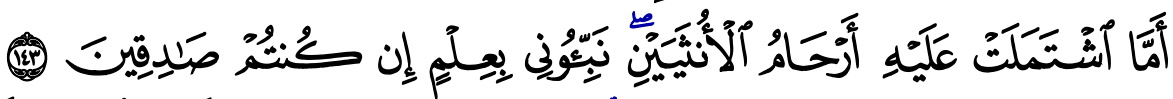

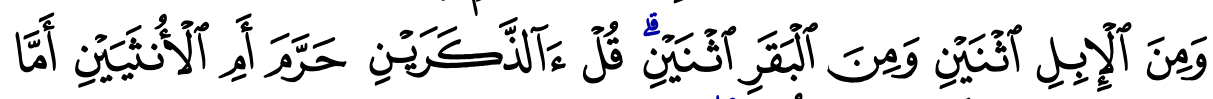

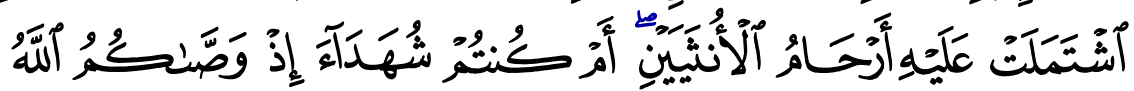

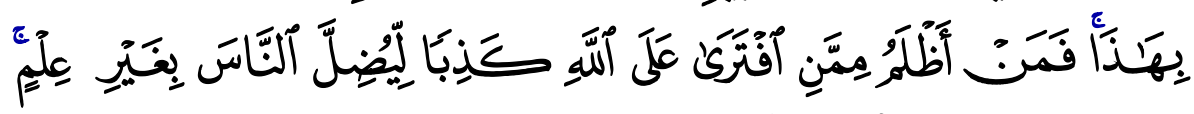

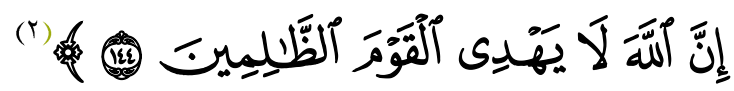

$$
\text { وفي علم الحيوان تعرف الأنعام بأها : }
$$

حيوانات ثديية ، بحترة ، من الحيوان تعرف الانعات باكا: الأعشاب ، وذات الحافر مزدوج الأصابع. ثديية أي لبونة وهي أعلى طائفة في الفقاريات من الحيوان ، كما تتميز بأجسام

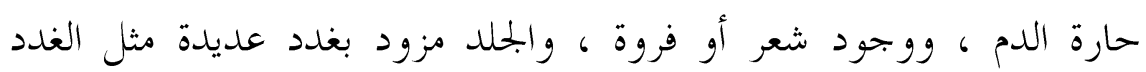

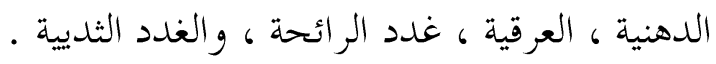


وهي ولود تتكاثر بالنسل ، وهذا يعني أن صغارها تكبر في أحشائها ، وتولد كاملة و (1) ومعنى بحترة أي أها ذات معدة ضخمة مكونة من أربع غرف ، و وأها عندما

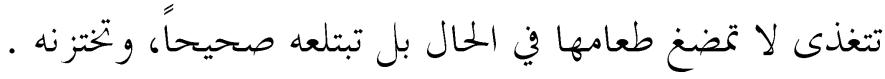

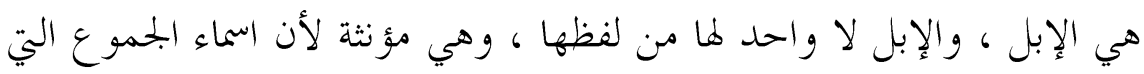

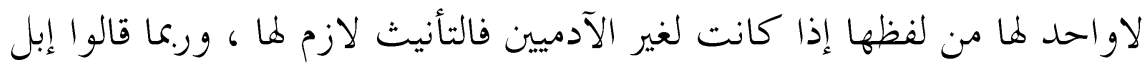

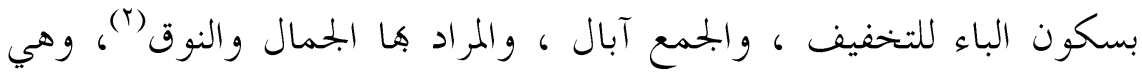

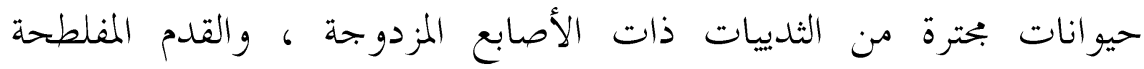
(المبطنة (T) (ن)

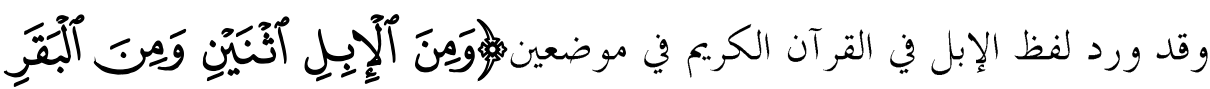

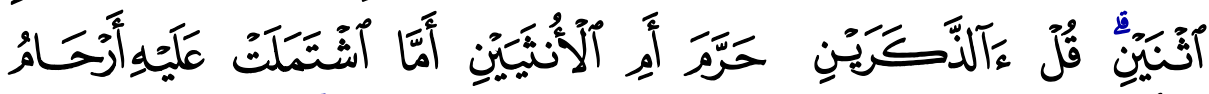

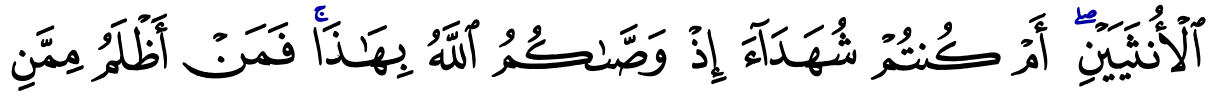

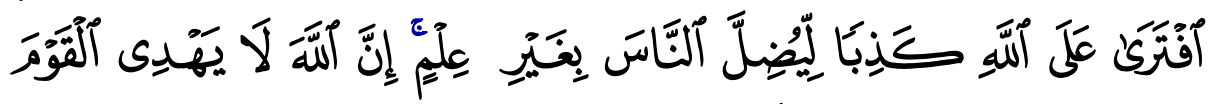

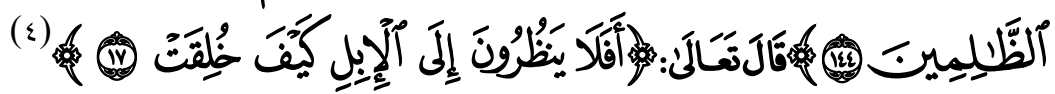

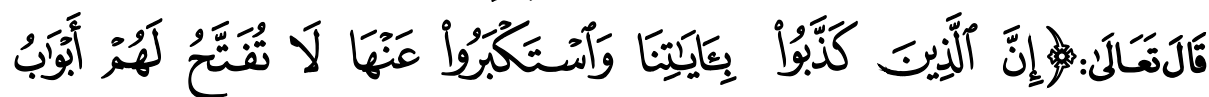

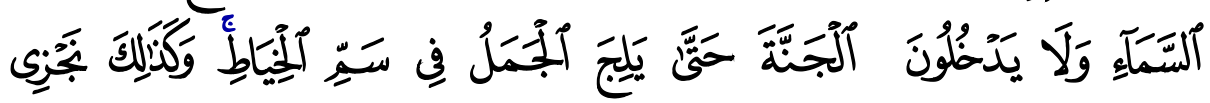

(o)

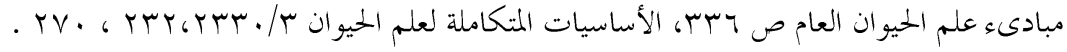

$$
\begin{aligned}
& \text { المعجم الوجيز صب } \\
& \text { الإبل تربية ورعاية و إنتاج د/حمدي محمد قنديل ص ع ع-ه ب، الإبل العربية إنتاج وتراث د/ السيد أحمد جهاد } \\
& \text {. } 0 .-\sum 9 \\
& \text { الأنعام: ع } \\
& \text { | الغاشية: }
\end{aligned}
$$




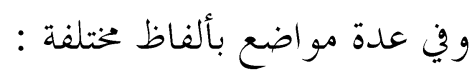

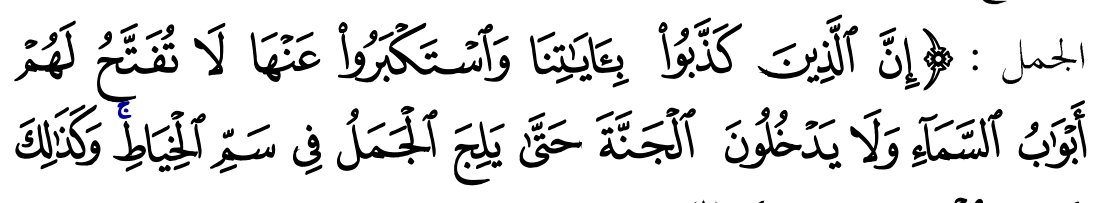

(1)

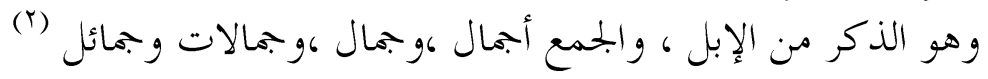

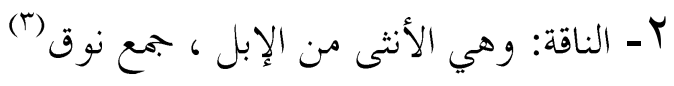

$$
\begin{aligned}
& \text { و وعتى مبصرة أي معجزة. }
\end{aligned}
$$

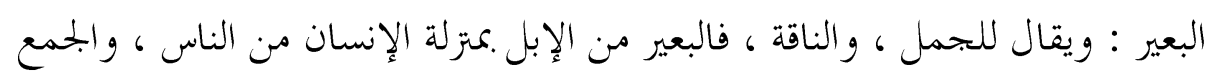
أباعر ، وأباعير

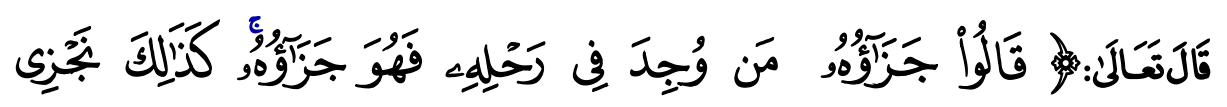

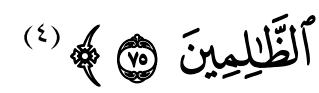

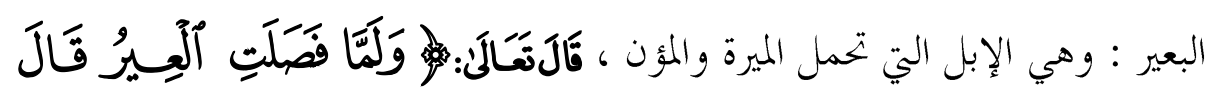

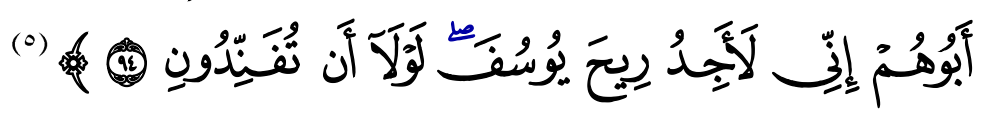

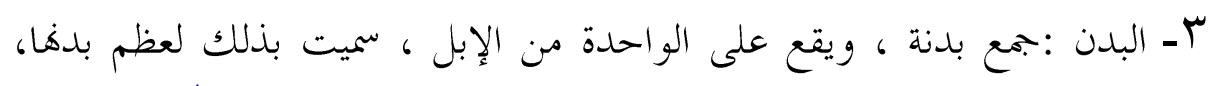

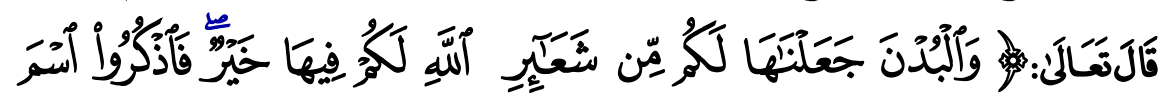

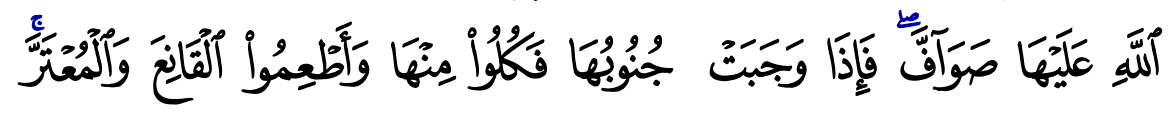

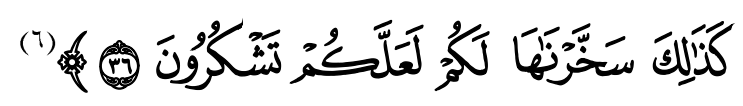

$$
\begin{aligned}
& \text { | (1) (1) }
\end{aligned}
$$

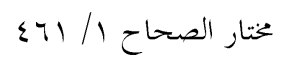

$$
\begin{aligned}
& \text { (T) }
\end{aligned}
$$

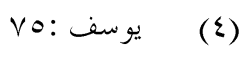

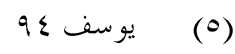

$$
\begin{aligned}
& \text { الحج: بونف }
\end{aligned}
$$




\section{الهيم : وهي الإبل العطاش ع

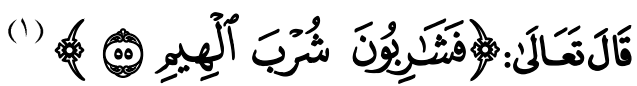

ــ العشار: وهي الناقة التي أتى عليها من وقت الحمل عشرة أشهر

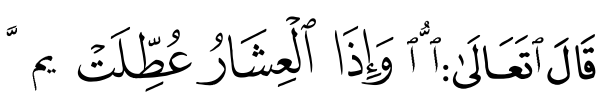

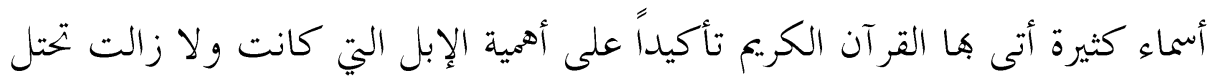

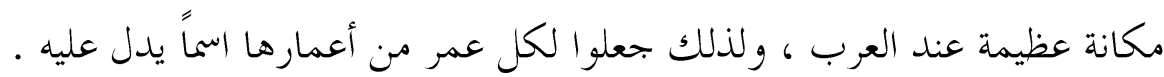

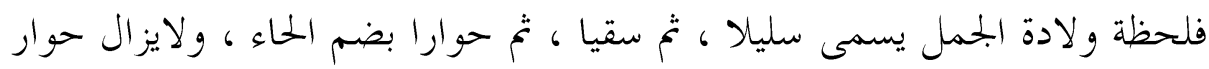
حتى إذا فصل عن أمه فطيماً سمي فصيلاً . وفي عمر سنتين يسمى ابن خخاض ، والأنثى ابنة غخاض ،لأنه فصل عن عن أمه ، وألحق

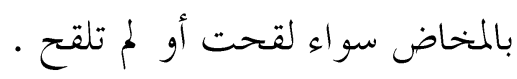

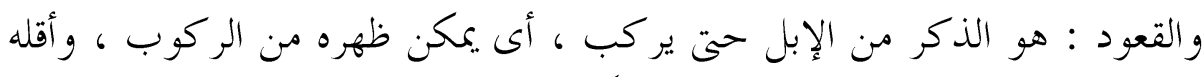

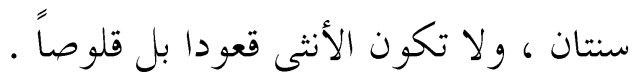

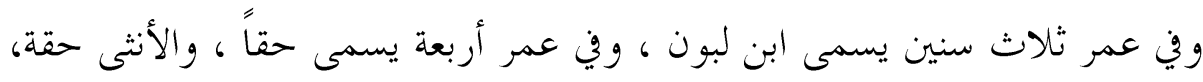

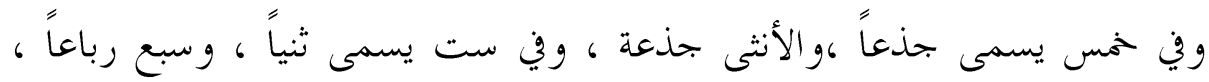

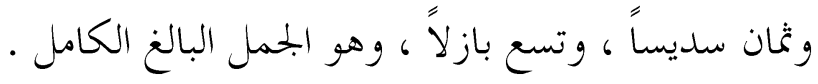

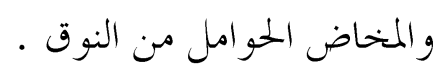

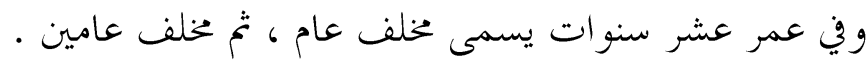

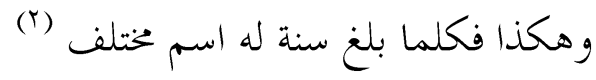

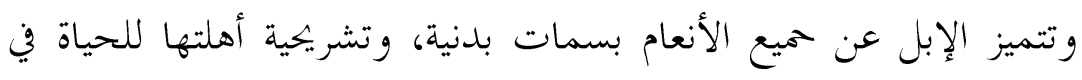

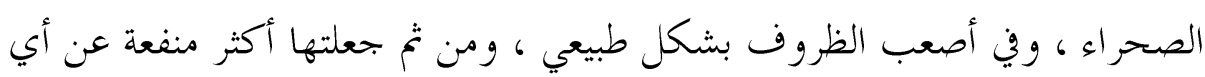

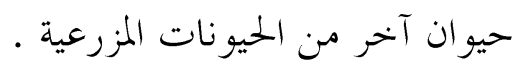


ثانياً : البقر : اسم جنس ، والبقرة تقع على الذكر والأنثى ، والهاء

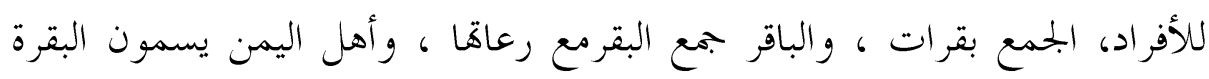
باقورة (1)

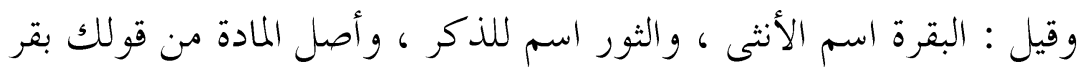

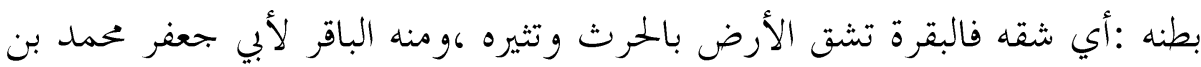

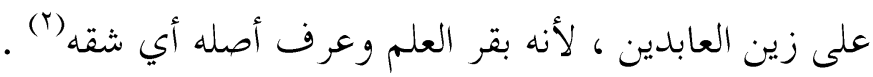

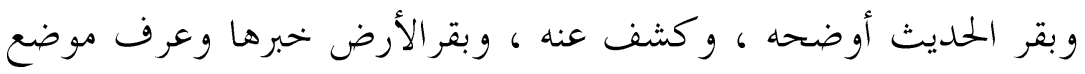

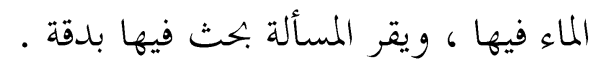

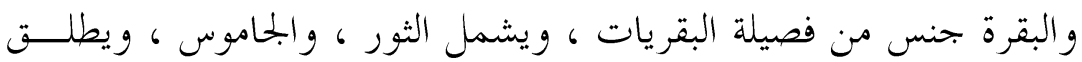

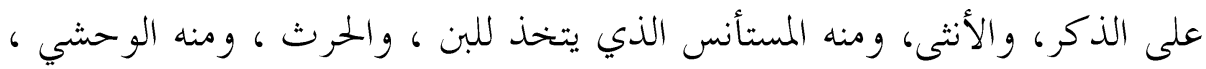

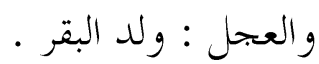

$$
\text { و والبقر حيوانات ثديية بحترة من اكلات الأعشاب . }
$$

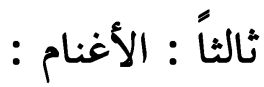

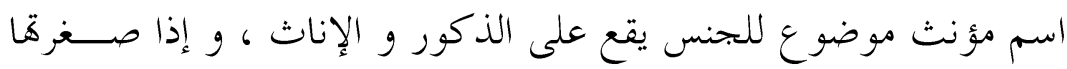

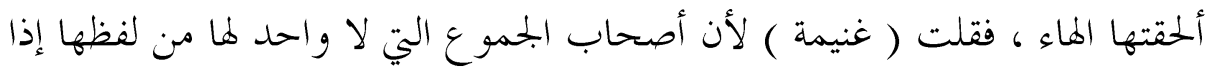

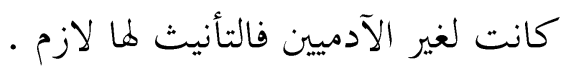

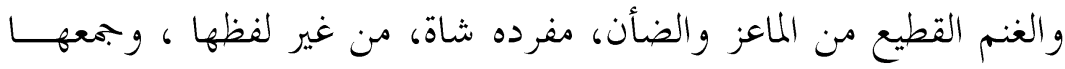

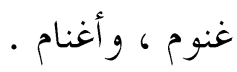
وهي حيوانات ثديية بحترة ، من العائلة البقرية ، ومن بجوفات القـــرون ،

$$
\text { اكلات الأعشاب (r) آنات }
$$

$$
\begin{aligned}
& \text { مختار الصحاح (1) } \\
& \text { لسان العرب (1/ / Tr/ }
\end{aligned}
$$

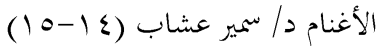




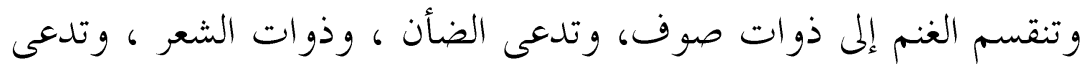

الماعز ، وذكر الضأن يدعى الكبش ، أو الخروف ، وأنثاه تدعى الشاة أوالنعجة .

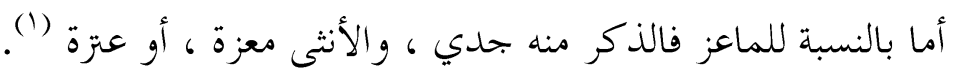

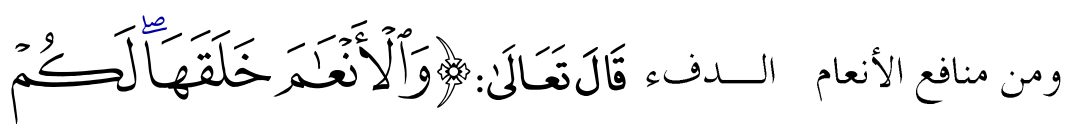

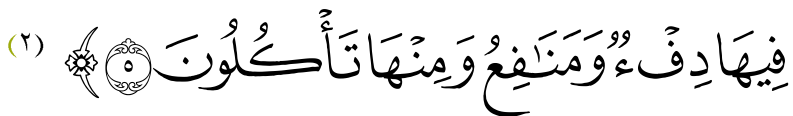

يمتن الله على عباده بما خلق لهم من الأنعام، و.بما جعل فيها مــن المصـــالح

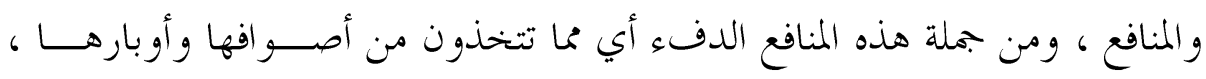

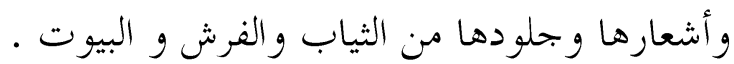

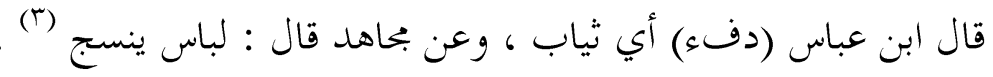

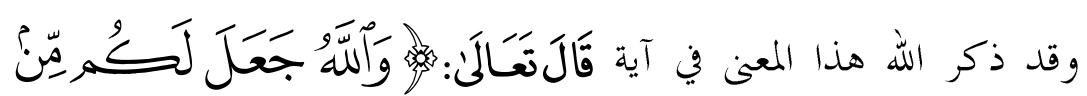

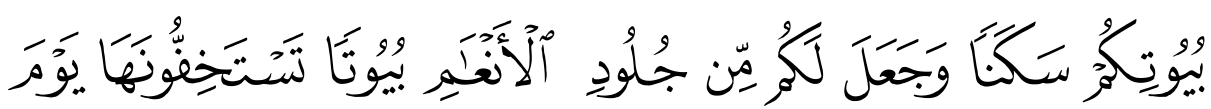

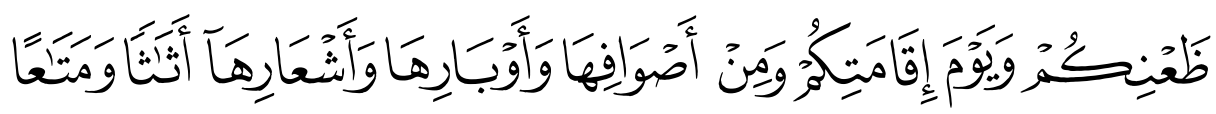
(纟)

أي وجعل سبحانه لكم من أصواف الضأن ، وأوبار الإبل ، وأشعار المعز ، أثناثا أي ما يتمتع به في البيت خاصة من الفرش ، و البسط ، و الغطاء ، و الوطاء .

$$
\begin{aligned}
& \text { الماعز و الغنام تربية و إنتاج د/ مصطفى محمد عاشور ص 11. } \\
& \text { النحل: ه }
\end{aligned}
$$

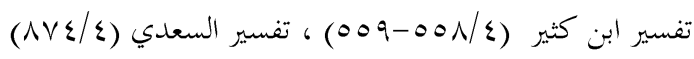

$$
\begin{aligned}
& \text { النحل: 1. }
\end{aligned}
$$




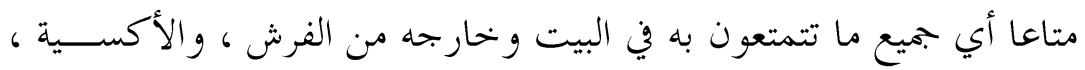

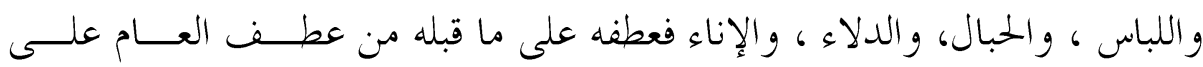
(1) الخناص (لدباص

كما أننا خصل على اللبن من الأنعام ، وهو من أفضل الأشربة ، وقد قال-

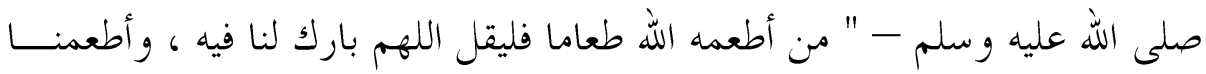

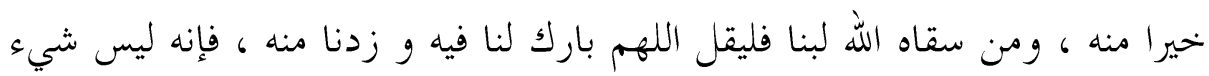

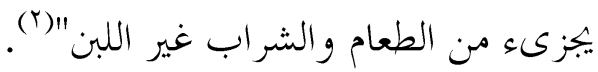

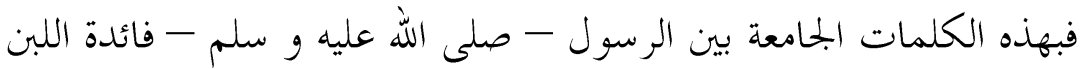

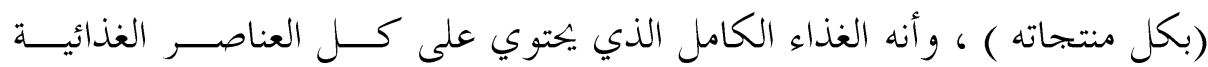

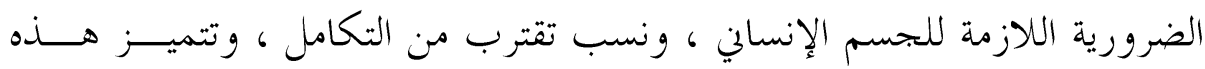

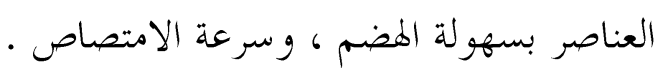

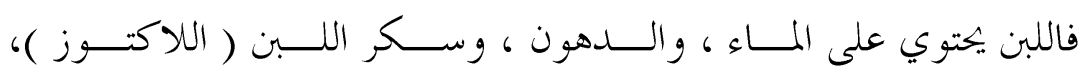

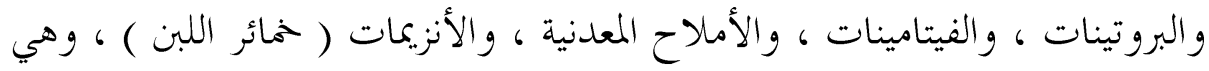

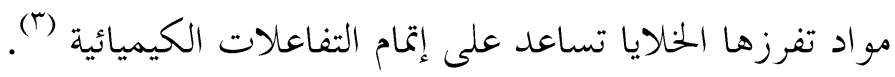

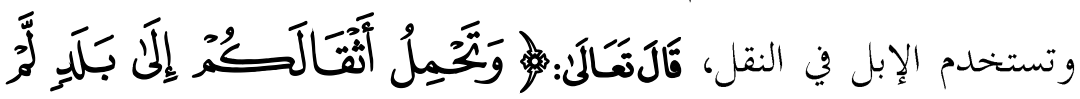

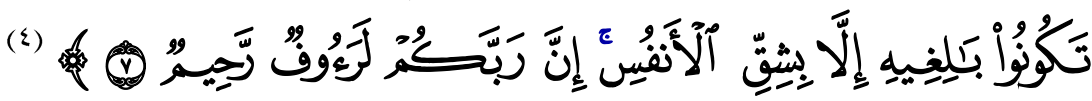

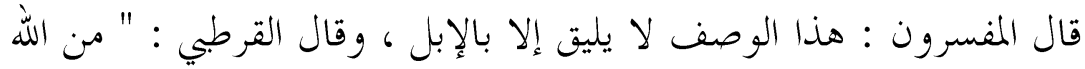

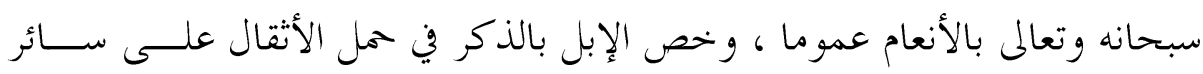

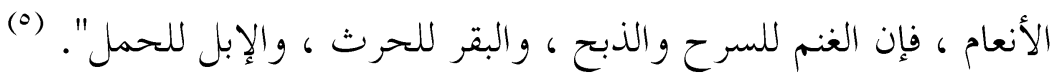

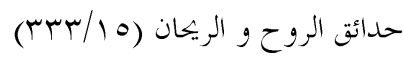

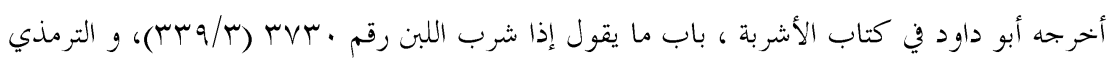

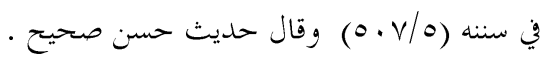

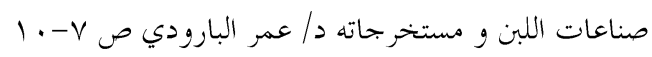

$$
\begin{aligned}
& \text { النحل }
\end{aligned}
$$

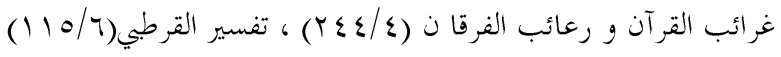




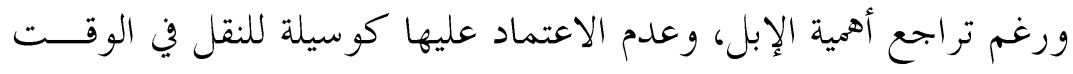

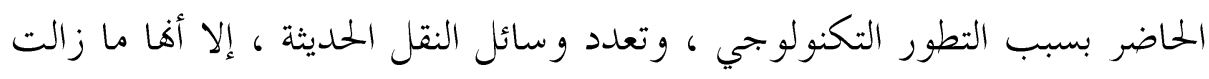

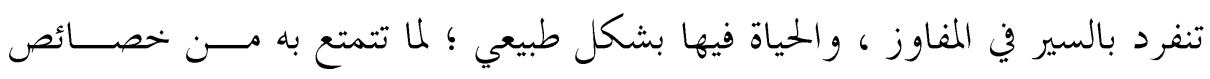

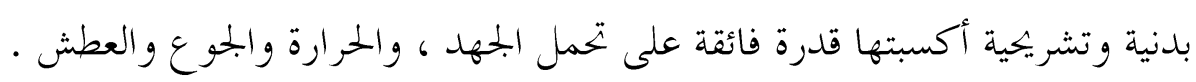

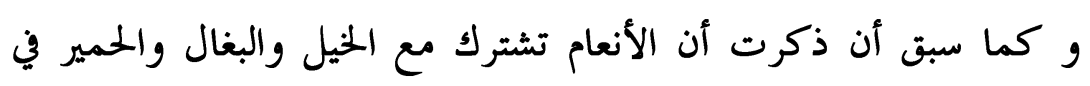

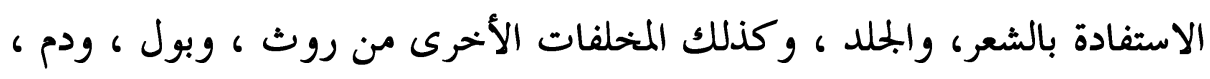

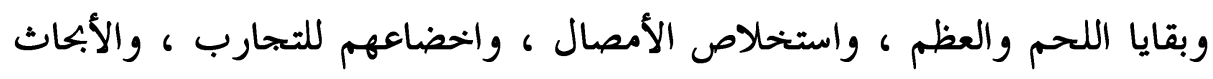

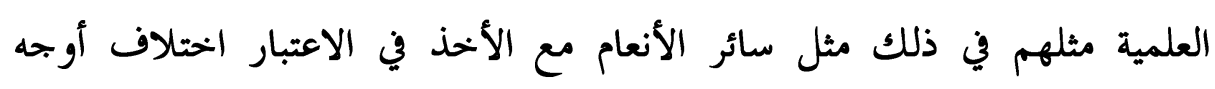
الاستعمال باختلاف الحل و الحرمة . ومن أعظم هذه المنافع أن معظم غذاء الإنسان من لحوم ، الحان ، وشحوم ، وألبان الأنعام

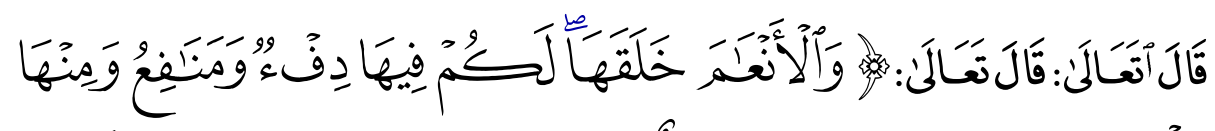

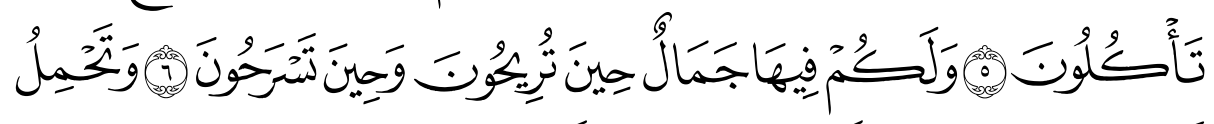

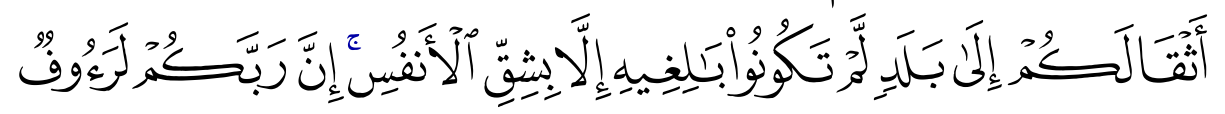

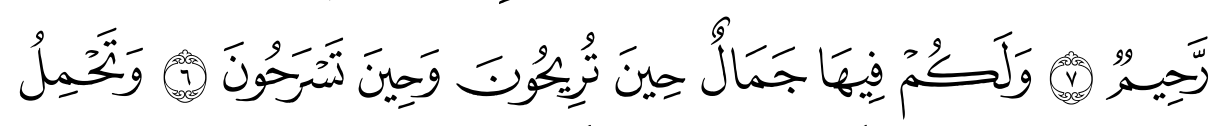

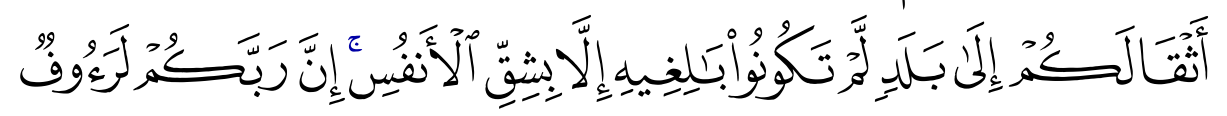
(")

كذلك من النعم التي أنعم الله هما علينا أننا لنا فيها جمال والجمال هي رقة

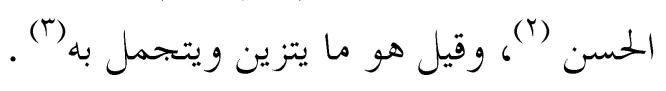

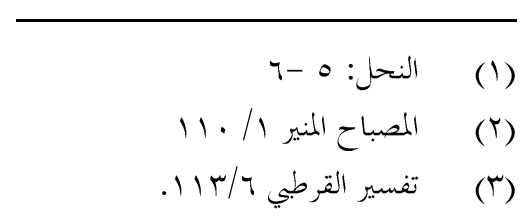


ومعنى قوله ( و لكم فيها جمال) أي زينة في الخلق والشكل والصورة ،

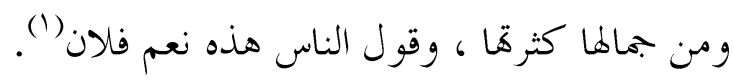

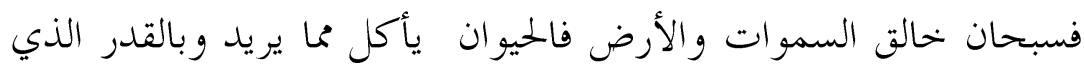

يريده ، لا مما يريد البشر ، ولا بالقدر الذي يريده البشر فكأن لها حرية واختيارا في

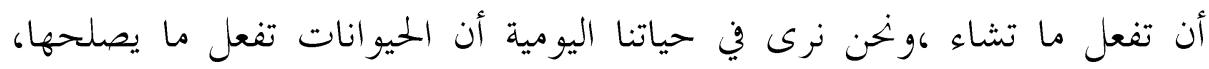
وتبتعد عما يضرها فنجد الحيوان يركض في الظل ، و يبتعد عن الحر ، ويشرب كئب الماء

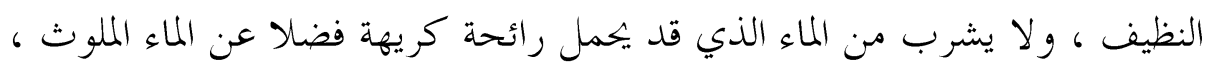
وإذا سار في الطريق يبتعد عن السيارات ونهوها ، كأن له عقلا يأتمر بأمره ، و وينتهي

بنهيه

وي الحقيقة الحيوان ليس له عقل وإلا فما الفرق بينه وبين الإنسان ؟

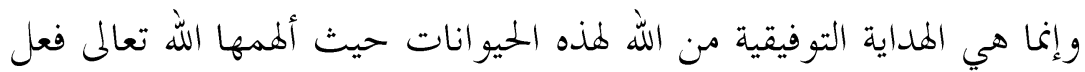

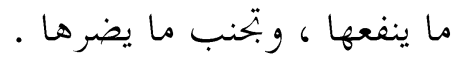

الحرث: المراد به هنا الزرع، ولكن الله سبحانه وتعالى يريد مناأن نعلم

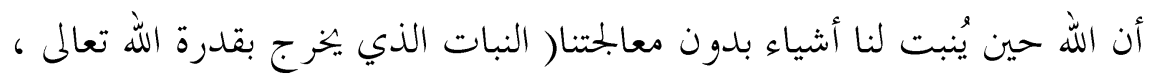

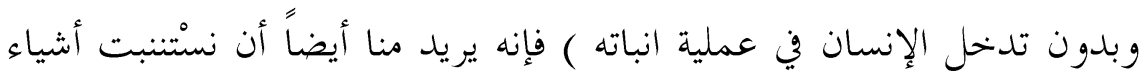
كعالجمتنا، وهذا لا يتأتى إلا بعملية الحرث.

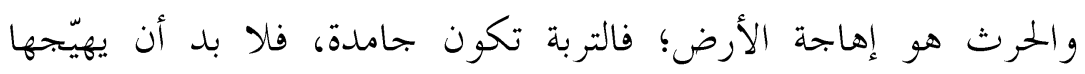

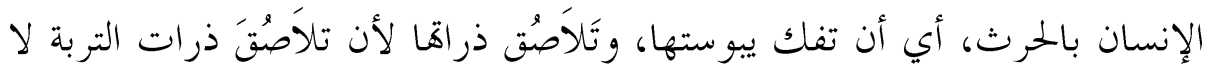

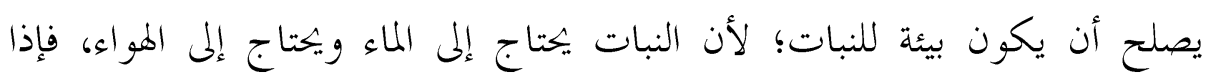
كانت التربة ذراهما متلاصقة فإن الهوء لا يستطيع أن يمر من خلالها ، ولذا ،فهي تحتاج إلى تفتيت هذه الذرات ، وهو ما يعرف بالحرث، ويحتاج من الإنسان أن يُمها للشعيرات البسيطة أن تخرج، وبتد تربة سهلة تتحرك فيها إلى أن تقوى. 
إذاً، فالحرث يثير الأرض، ويبعلها ليّنة مُتفتتة حتى تستطيع البذرة أن تنمو؛

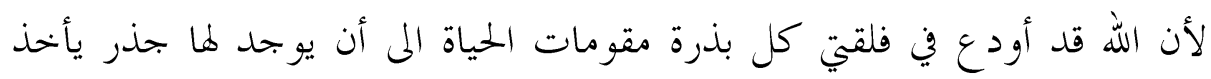

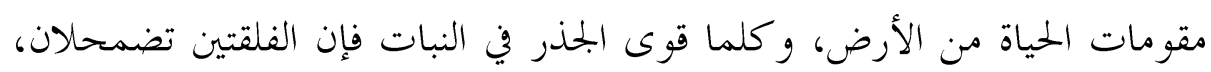

$$
\text { وتصير ان بحرد ورقتين. }
$$

وتقوم الفلقتان بتغذية النبتة إلى أن تستطيع أن تتغذى بنفسها من الأرض،

$$
\text { ولا يمكن حدوث ذلك إلا إذا كانت الأرض محروثة(1) . }
$$

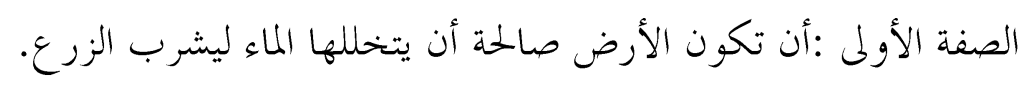

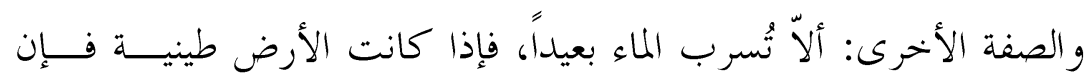

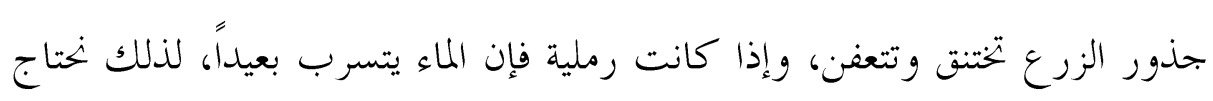

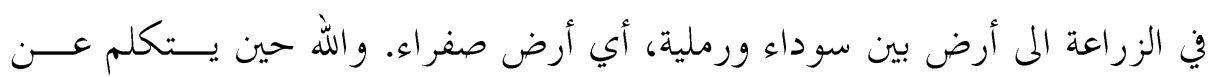

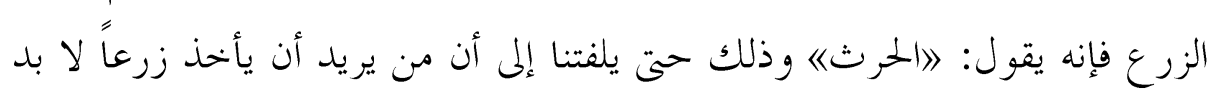

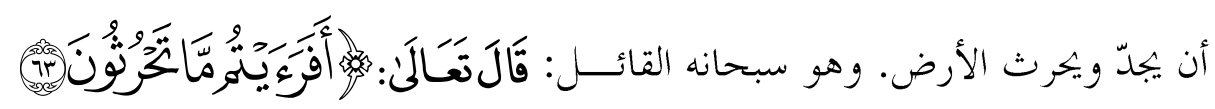

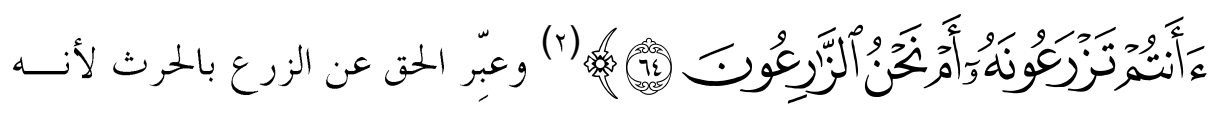

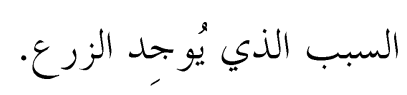

و كل ما تقدم من الشهوات من النساء والبنين والقناطير المقنطرة من الذهب

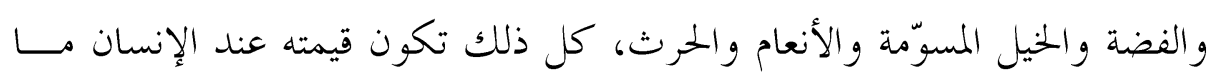

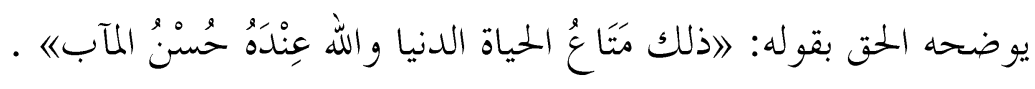

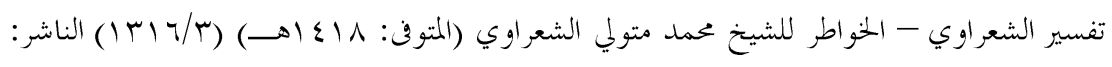

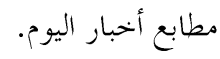

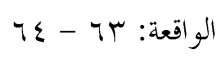




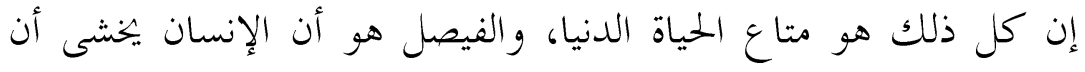

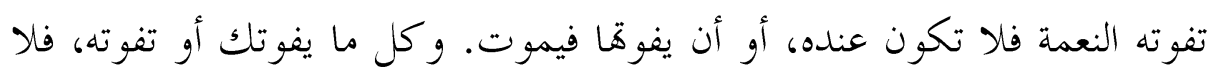

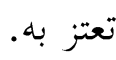

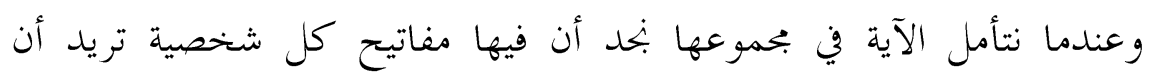

$$
\text { تنحرف عن منهج الله، إنه سبحانه يقول: }
$$

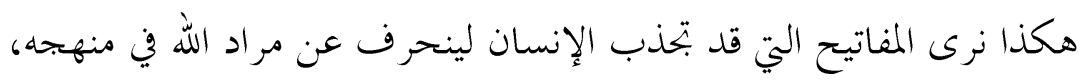

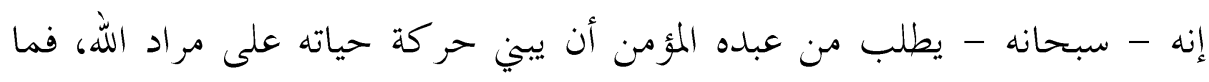

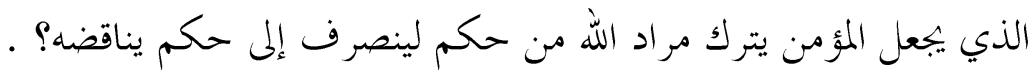

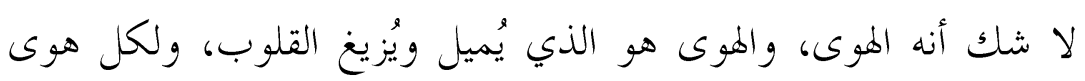

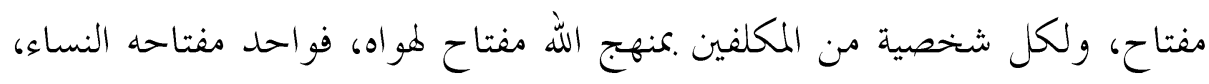

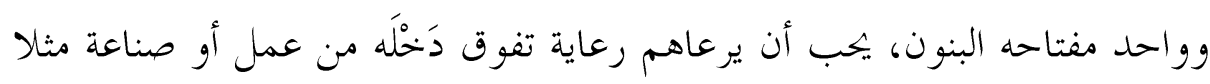

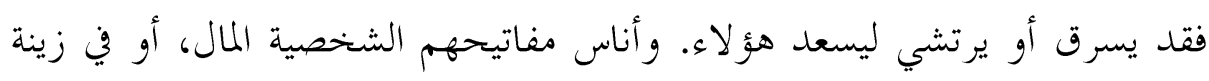

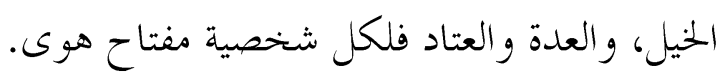

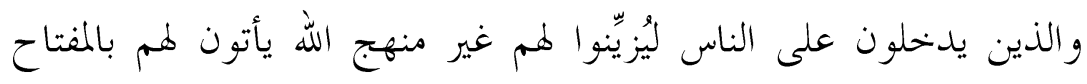

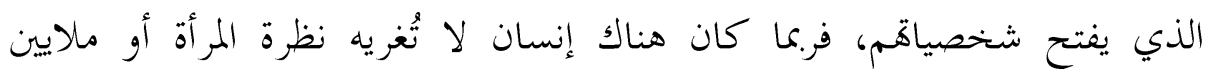

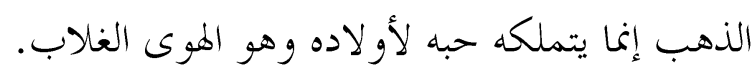

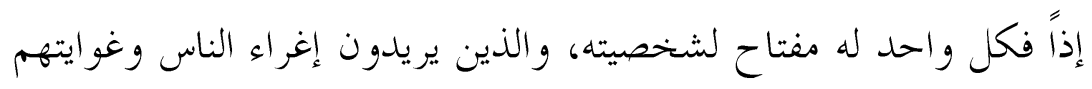
يعرفون مفاتيح من يريدون إغراءه وإغواءه.

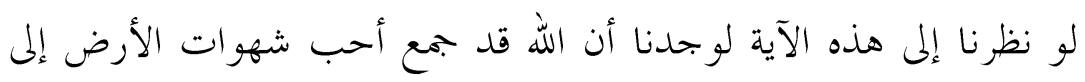

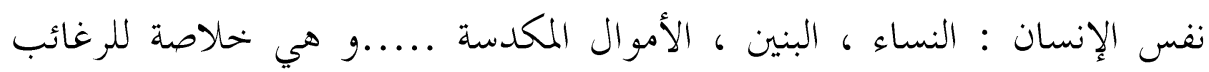

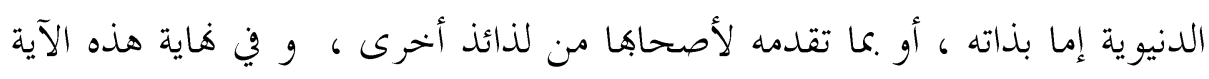

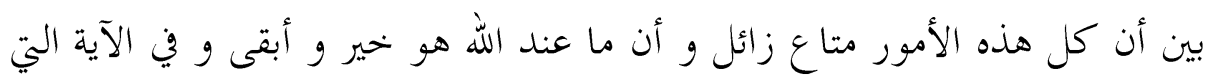

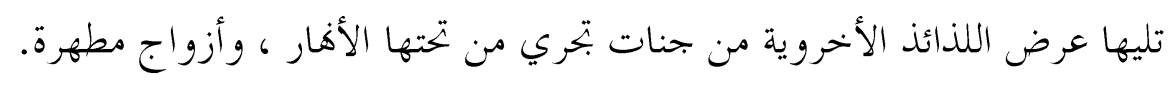




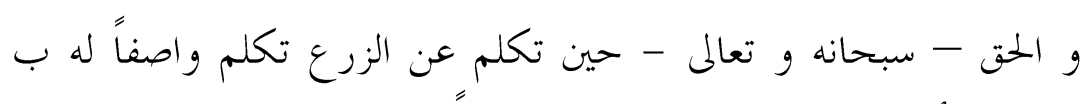

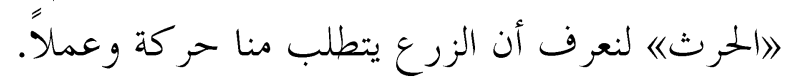

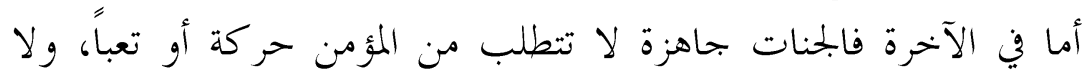

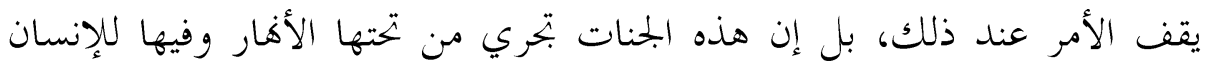
المؤمن ما وعده الله به:

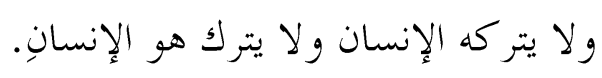

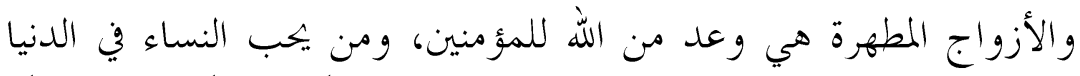

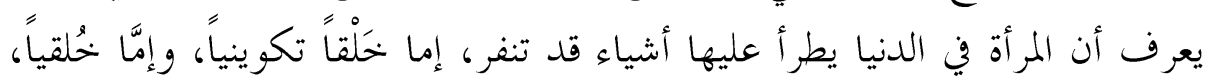

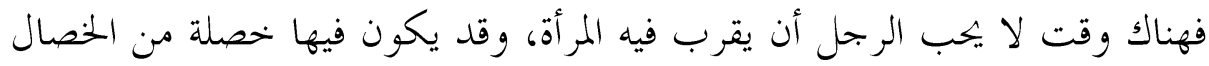
السيئة فيكره الإنسان جمالها.

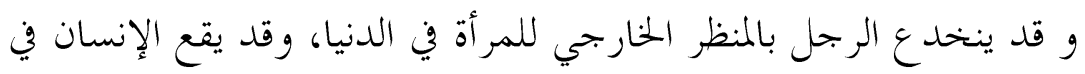

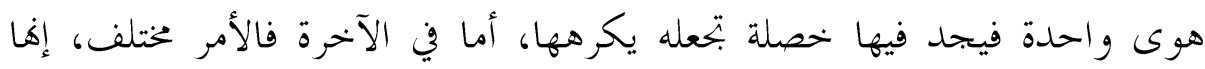

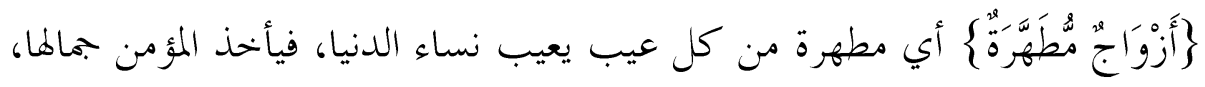

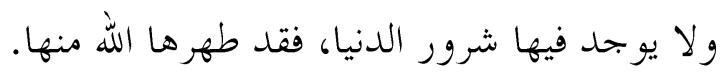

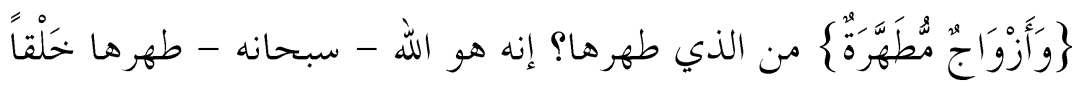

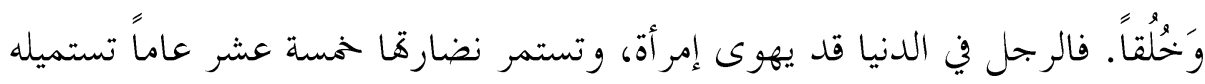

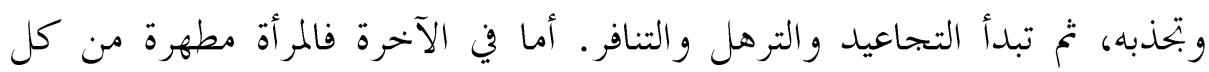

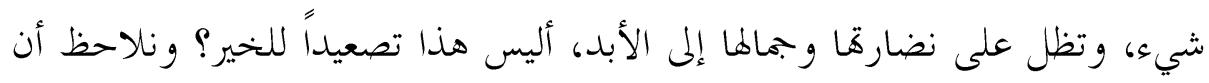

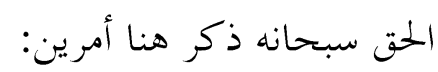
الأمر الأول: هو جنات تجري من تحتها الأفهار، ونقارن بينها وبين الحرث

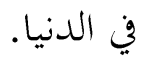

والأمر الآخر: هو الأزواج المطهرة، ونقارن بينها وبين النساء في الدنيا

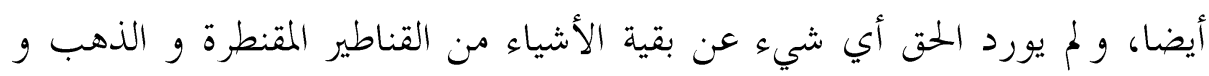

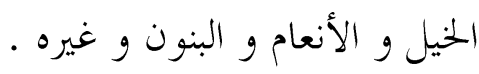


إننا نلاحظ أن الحق سبحانه وتعالى جعل الأمرين المزينين، واحداً يستهل به الأبه

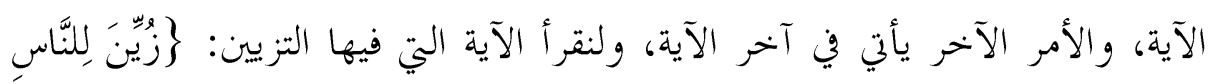

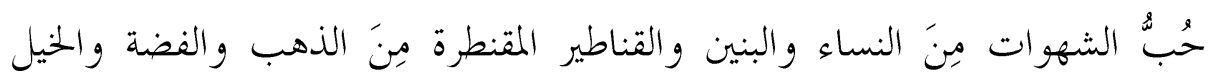

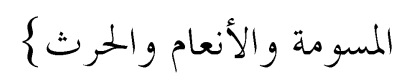

إن البداية هي النساء، ذلك هو القوس الأول، والنهاية هي الحرث وذلك

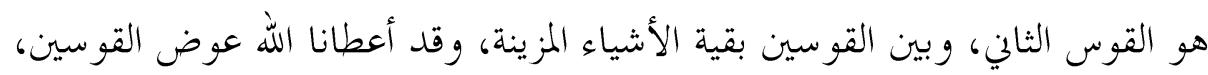

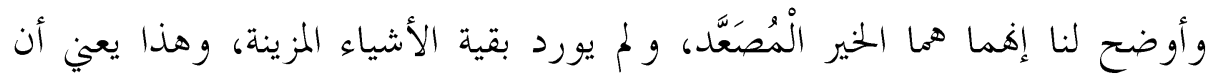

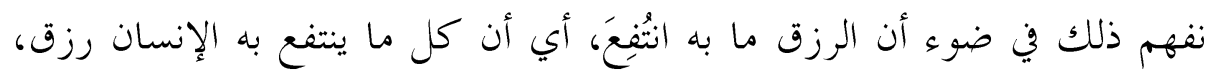

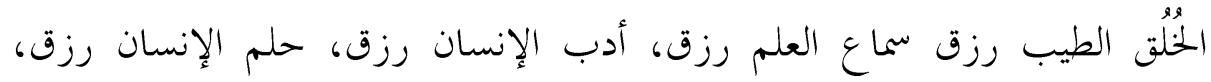

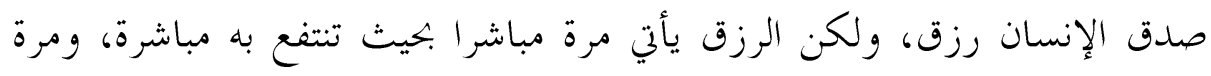

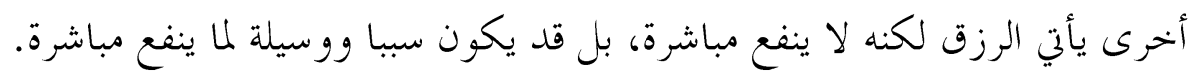

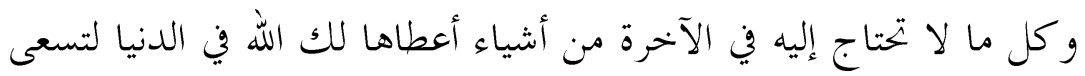

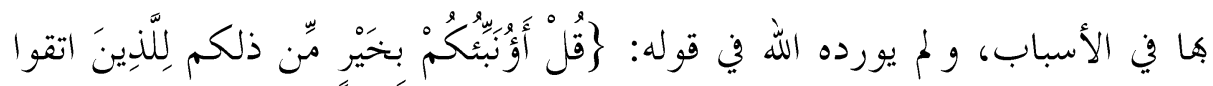

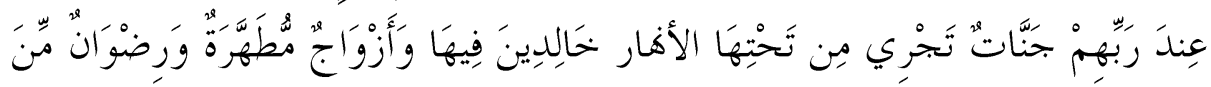

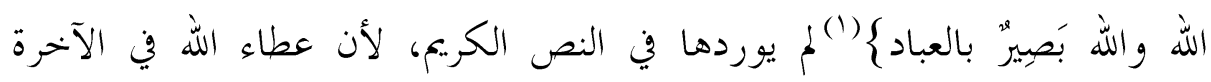

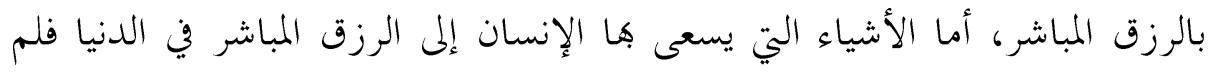

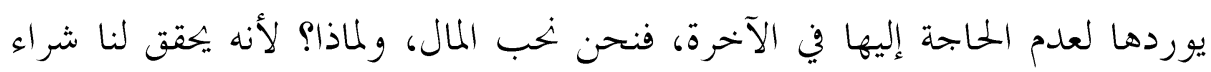

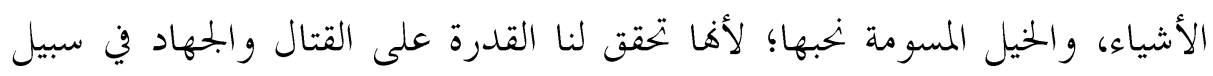

والأنعام؛ لتحقق لنا المتعة.

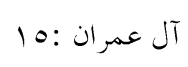


أما الجنة في الآخرة فالمؤمن يجد فيها كل ما تشتهيه الأنفس، وكل ما يخطر

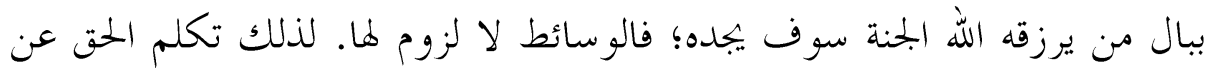

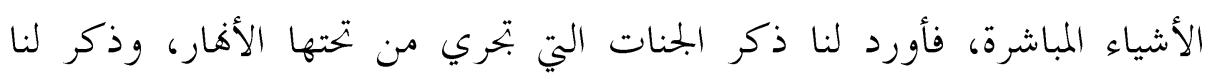

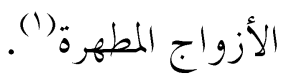

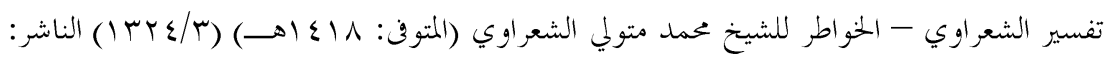

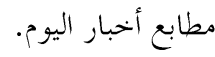




\section{الخاتمة}

و الله أسأل أن يحسن خاتمتنا في الأمور كلها ، وأن يحسن نياتنا ، ويتقبل أعمالنا : (n)

وفي الختام كان لهذا الموضوع عدد من النتائج ،والتي من أبرزها :-

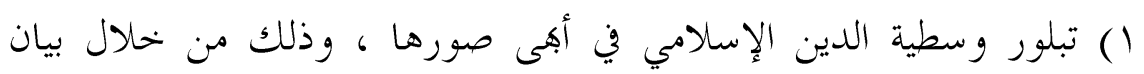

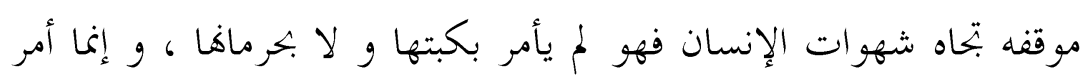

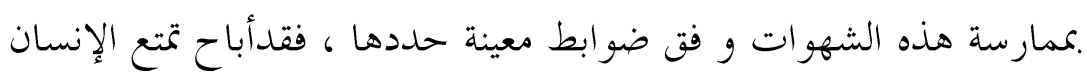

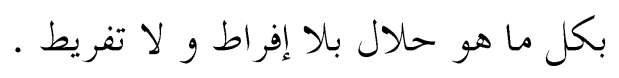

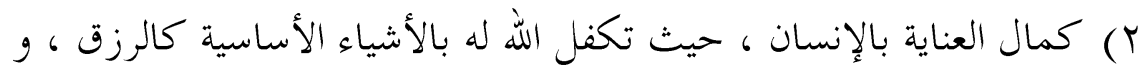

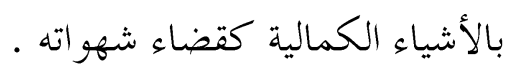

r) بيان ما جبلت عليه النفس الإنسانية من حب النساء ، والبنين ، والمال . .

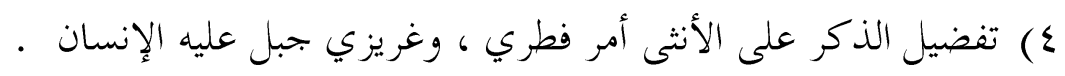

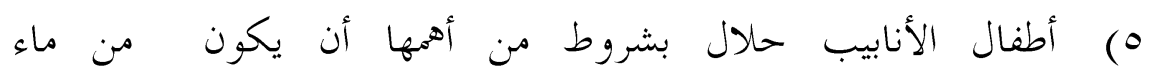

$$
\begin{aligned}
& \text { الزوج،وبويضة الزوجة . }
\end{aligned}
$$

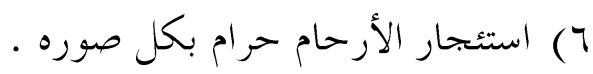

V استغلال النساء في السياسة ، و الاقتصاد ،وغيرها أسوأ استغلال.

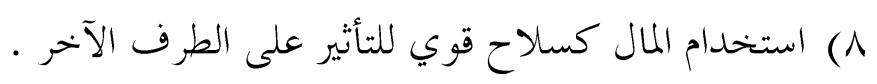

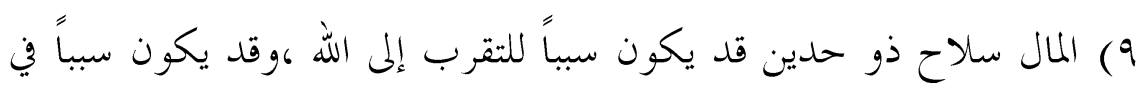
فساد الإنسان • 1) للحيوان قيمة اقتصاديةهائلة ، بالإضافة إلى أنه يخلق فرص عمل تحد من

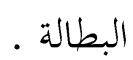


11) يجب على الإنسان تقديم الرعاية الكاملة للحيوان مقابل ما يقدمه من خيرات ، و وهو واجب ديني قبل أن يكون نفعياً .

r ( ) للخيل قيمة كبيرة لدى العرب لذا حفظو أنساها حفظهم أنساهم . r ا (1) بيجوز استخدام الزينة في حدود الشرع • 


\section{|ll}

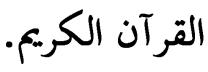

() تحفة الأريب بما في القر آن من الغريب لأبي حيان محمد بن يوسف بن علي

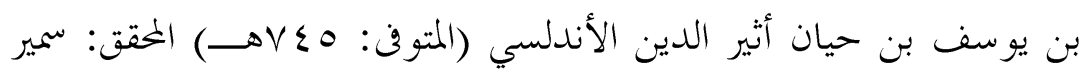

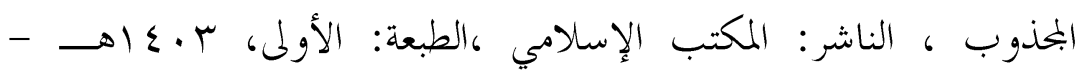

blapr

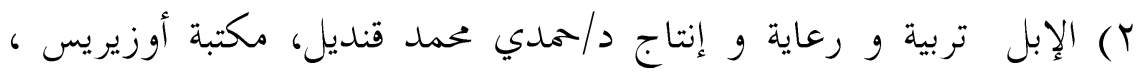

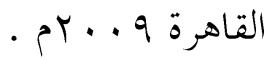

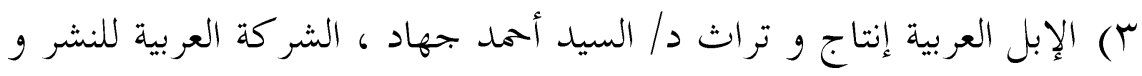

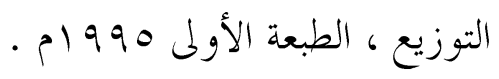

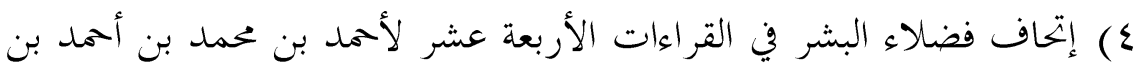

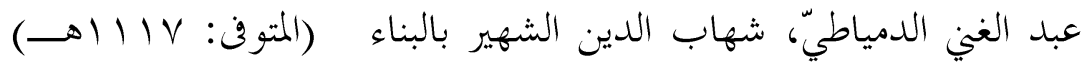

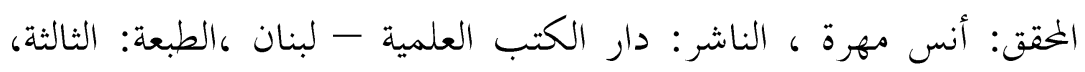
. $\rightarrow 1 \leqslant Y V-P T \cdot T$

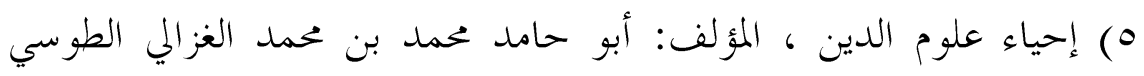

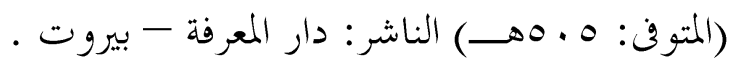

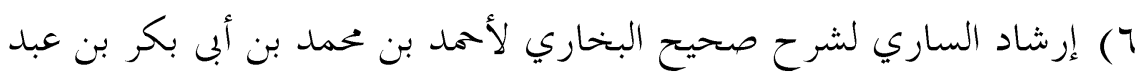

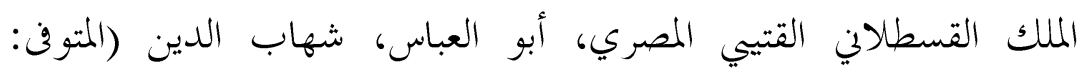

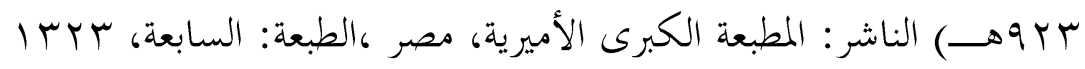
$\rightarrow$

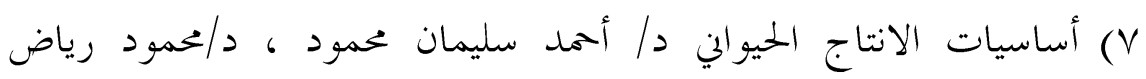

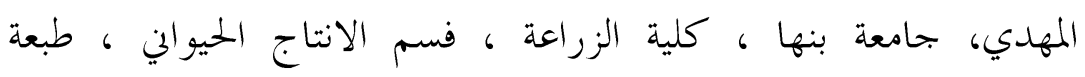
$.0,14$ 


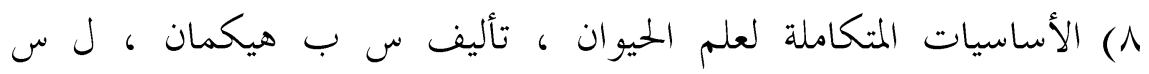

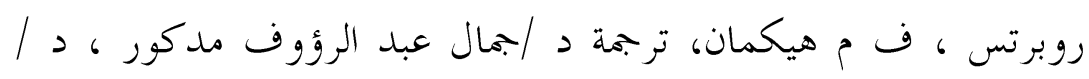

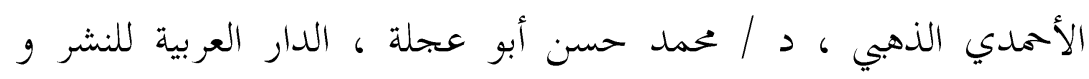

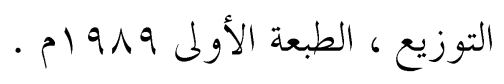

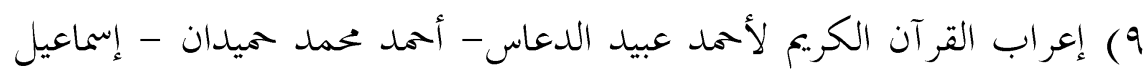

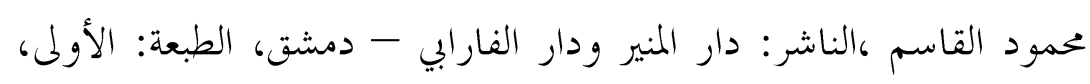
، $\rightarrow$ ) E T०

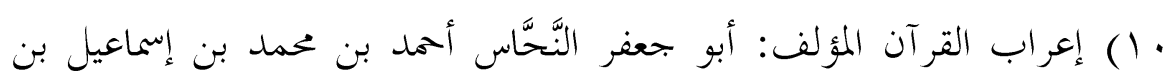

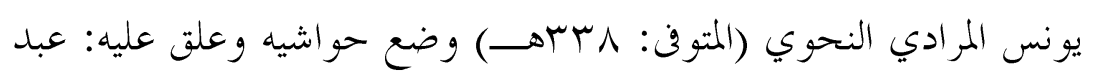

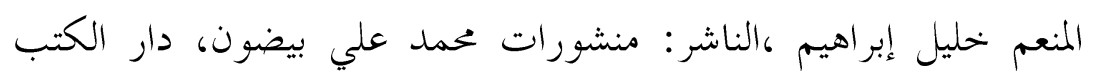

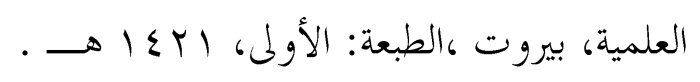

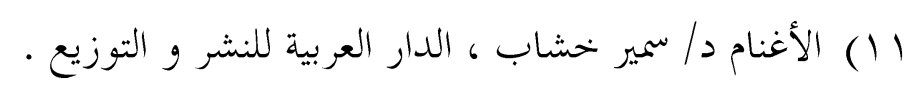

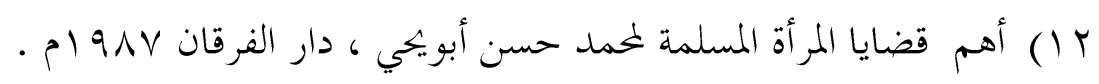

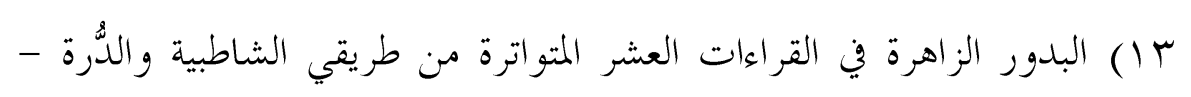

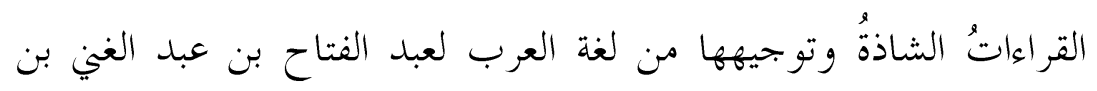

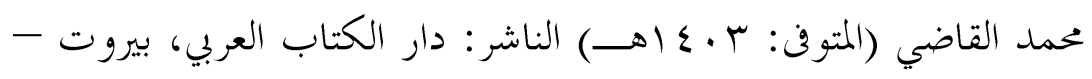
لبنان .

ـ ا ) البرهان في علوم القر آن لأبي عبد الله بدر الدين محمد بن عبد الله بن هادر

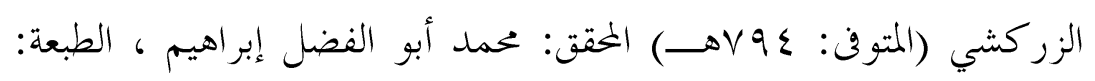

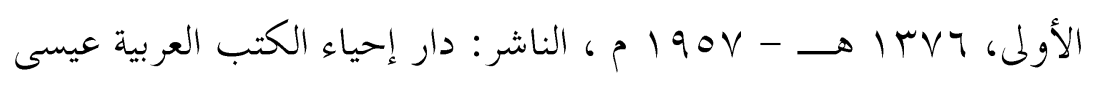

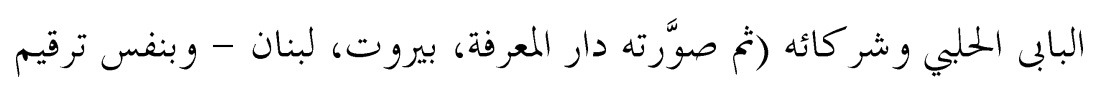
الصفحات) 
10) بناء الجتمع الإسلامي ،المؤلف: د نبيل السمالوطي ،الناشر: دار الشروق

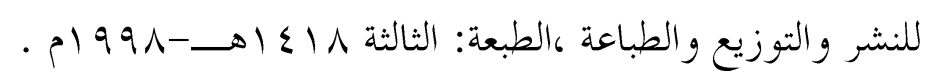

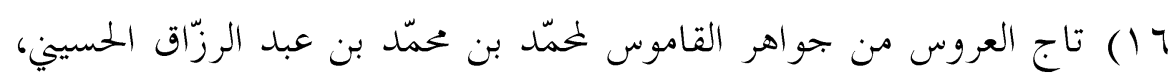

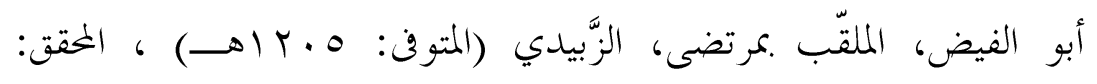

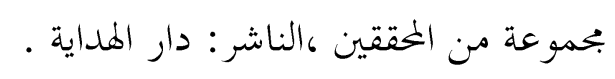

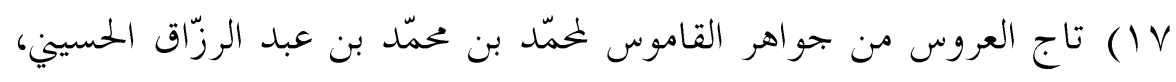

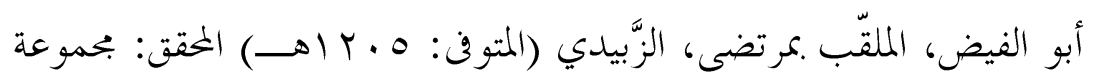

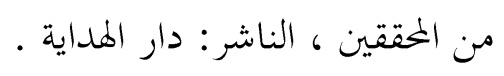

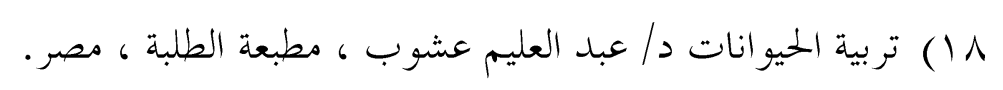

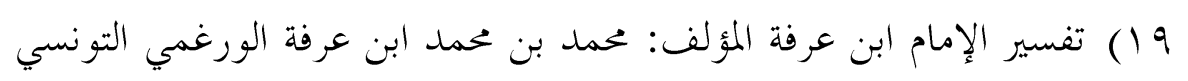

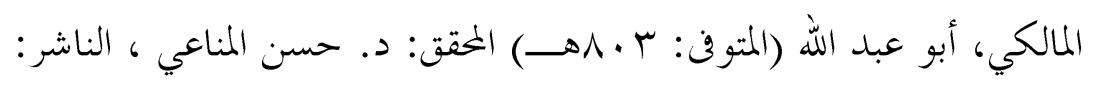

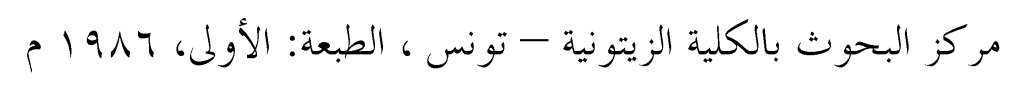

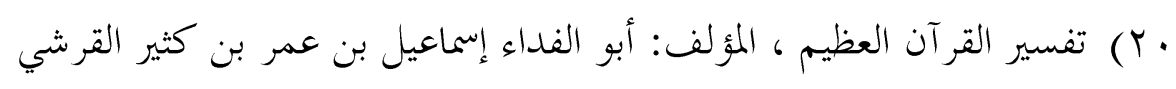

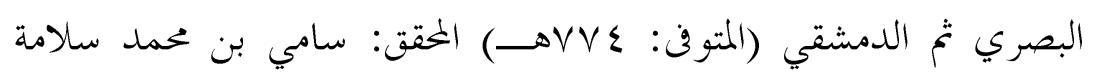

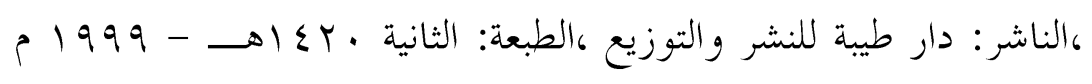

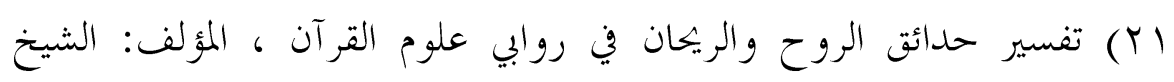

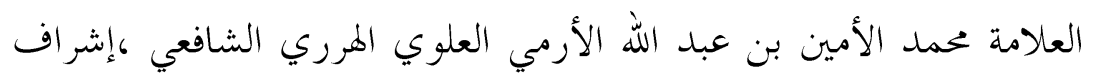

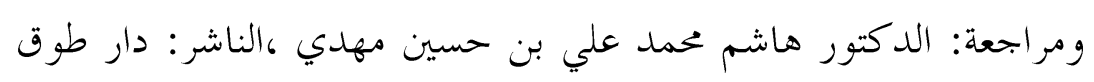

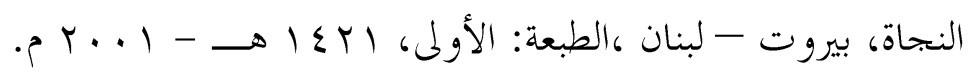

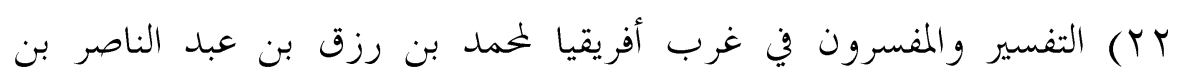

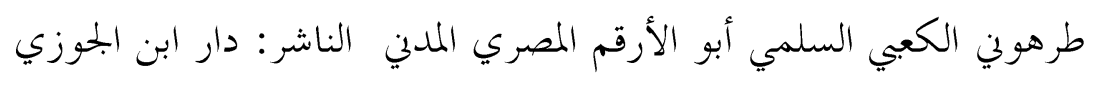

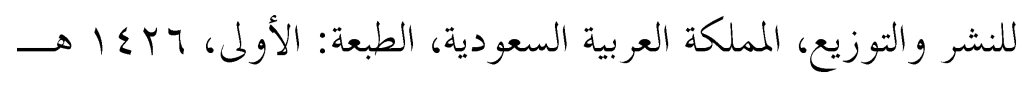




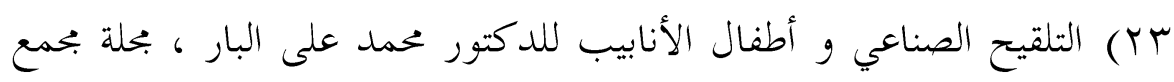

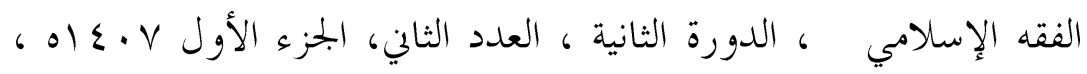

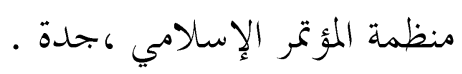

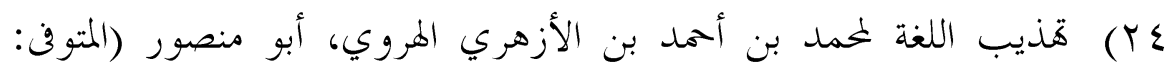
.

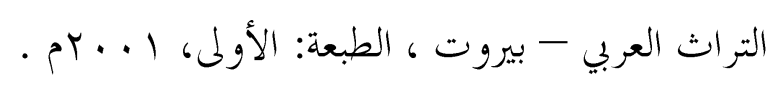

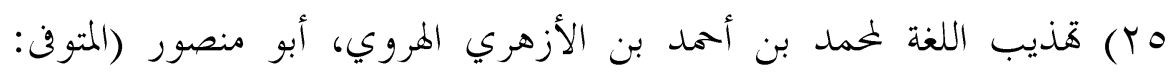

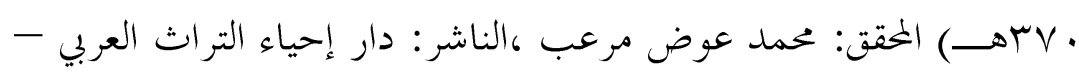

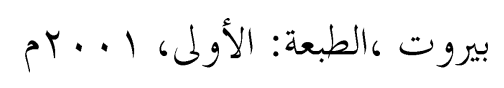

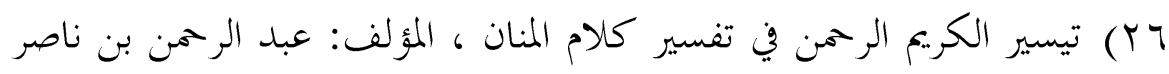

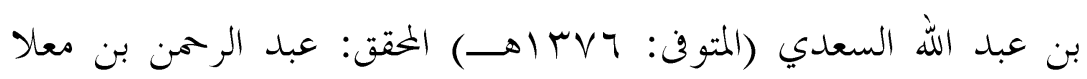

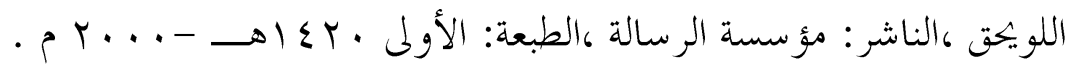

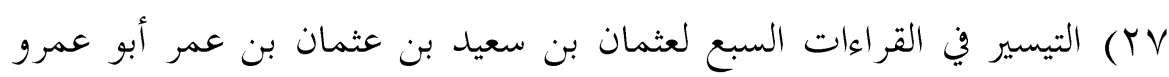

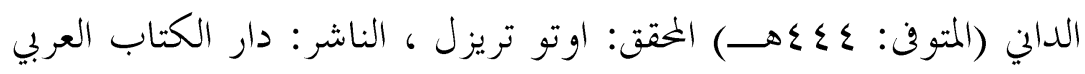

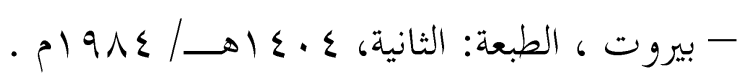

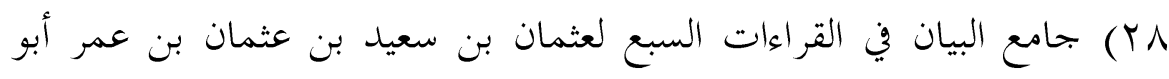

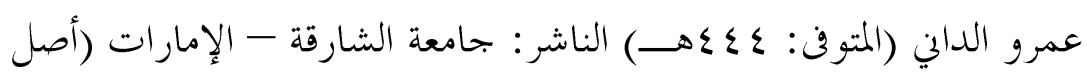

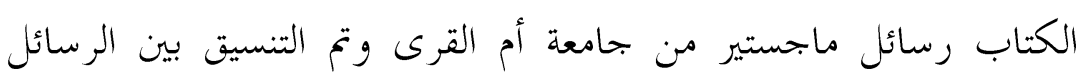

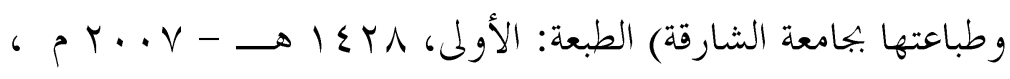

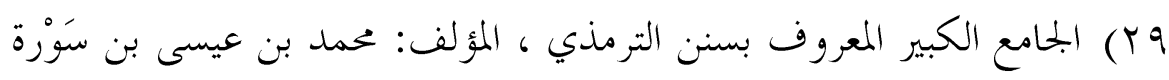

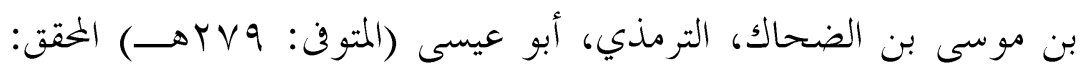

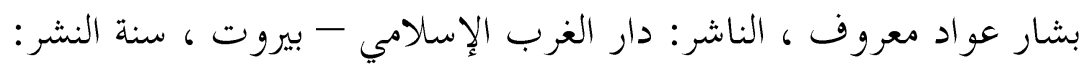




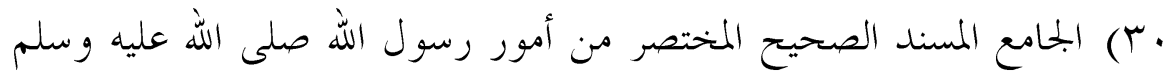

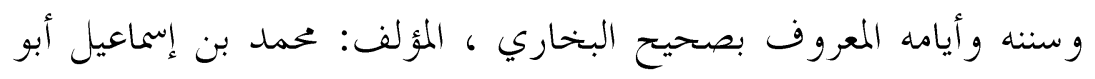

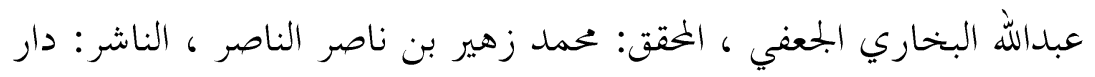

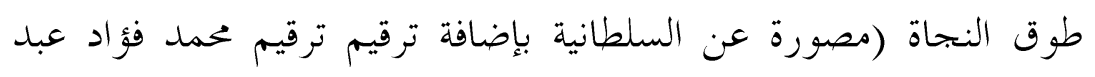

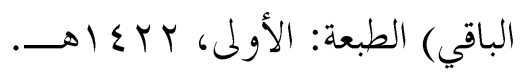

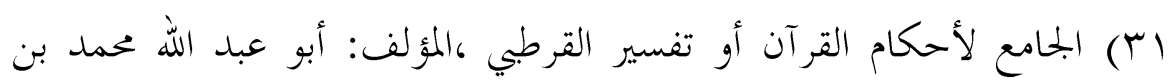

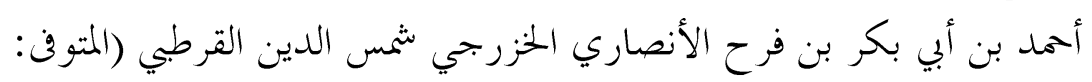

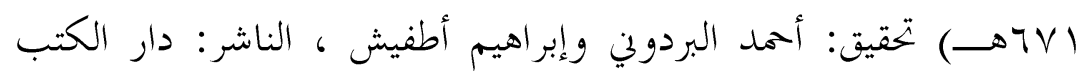

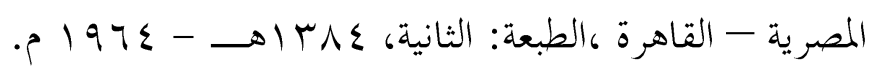

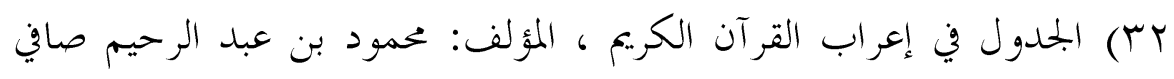

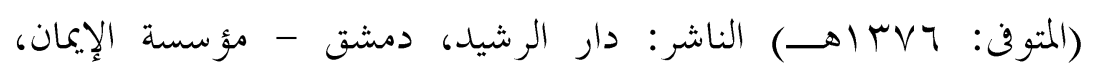

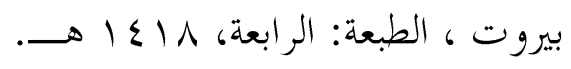
r

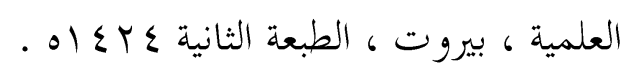

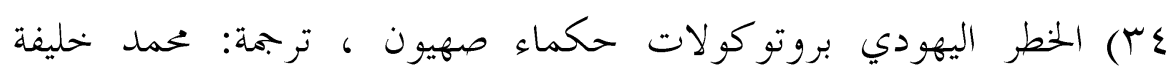

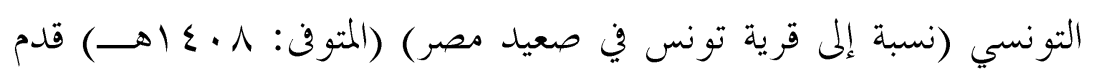

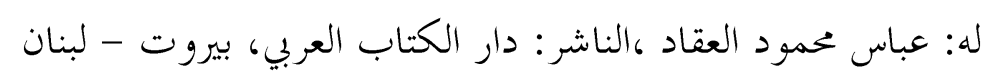

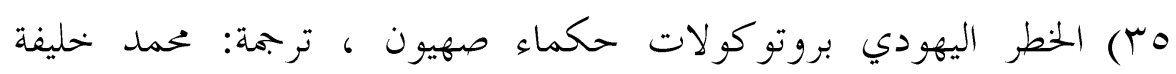

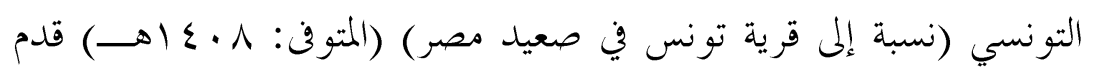

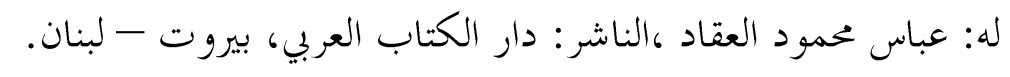

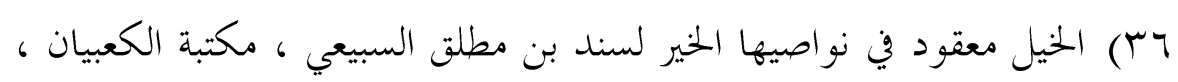

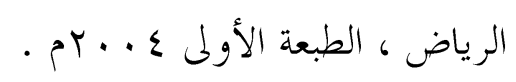


الرأي الصواب في الزينة و الحجاب لجواد موسى عفانة ، الطبعة الثانية - $\rightarrow 1 \leqslant r 46 r \cdot 10$

人ץ) الرحيق المختوم (مع بعض التعديلات والزيادات من د علاء الدين زعتري

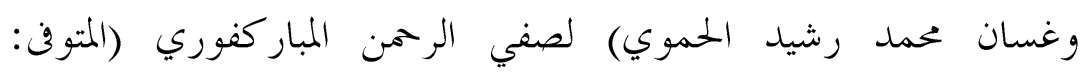

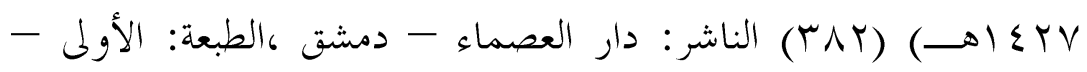
$.01 \leqslant Y V$

جrr) الروض الأنف في شرح السيرة النبوية لأبي القاسم عبد الرحمن بن عبد الله

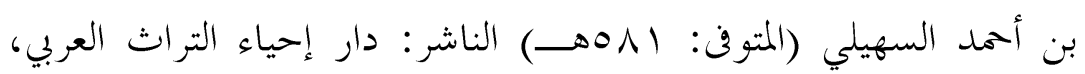

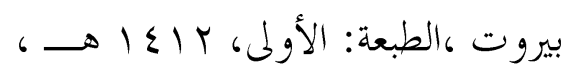

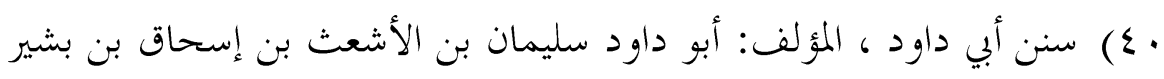

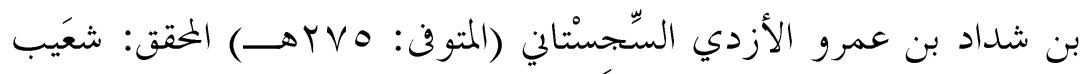

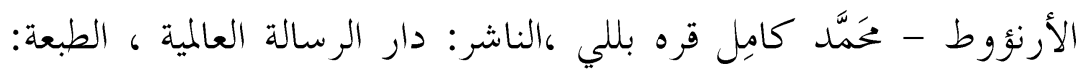

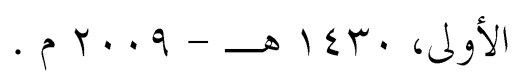

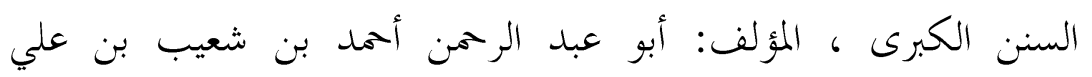

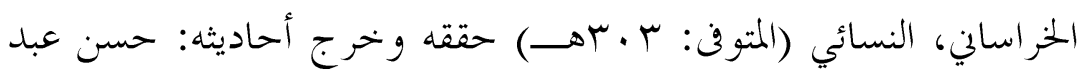

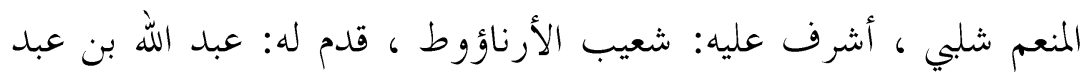

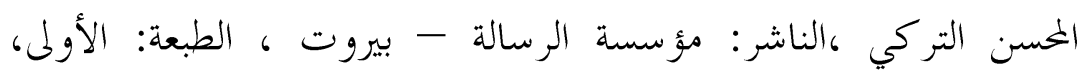

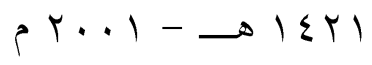

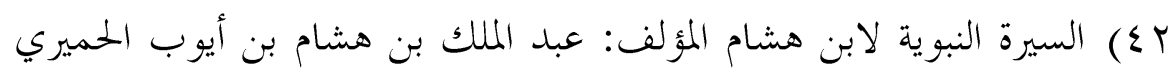

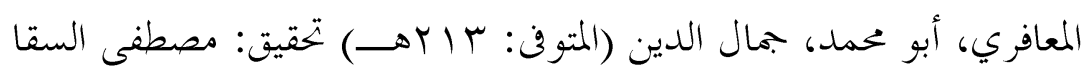

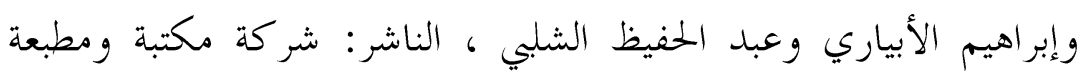

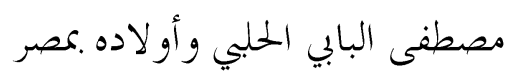


rع) شرح السنة المؤلف: محيي السنة، أبو محمد الحسين بن مسعود بن محمد بن

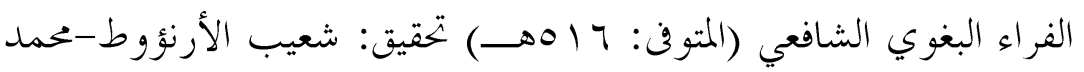

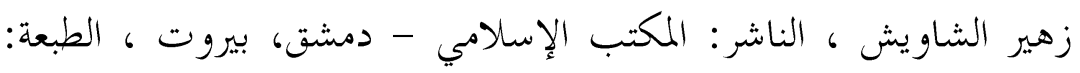

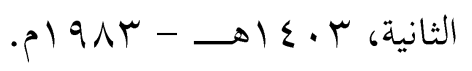

§؟) شرح كفاية المتحفظ (تحرير الرواية في تقرير الكفاية) لمحمد بن الطيب

الفاسي

ع §) صحيح ابن حبان بترتيب ابن بلبان ، المؤلف: محمد بن حبان بن أحمد بن

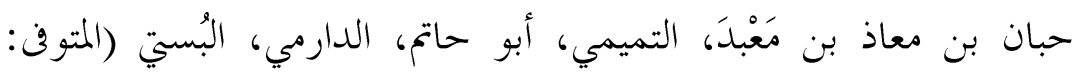

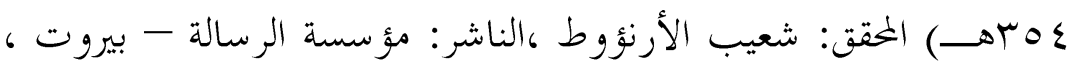

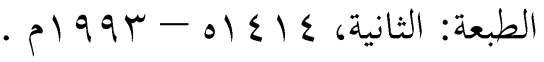

7§ ) صدق البيان في طب الحيو ان ،جرجس طنوس عولي الصيدلى ، بيروت.

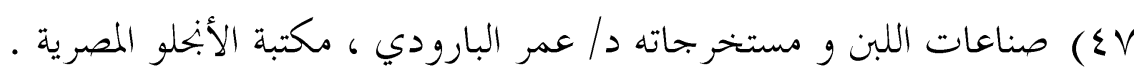
الطبعة: الثانية، هVr اهــ - 1900 م

^^) طرق الاستفادة أو التخلص من مخلفات المسالخ ، المملكة العربية السعودية

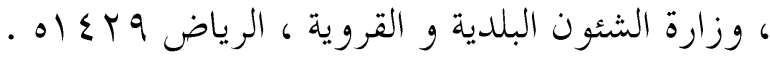

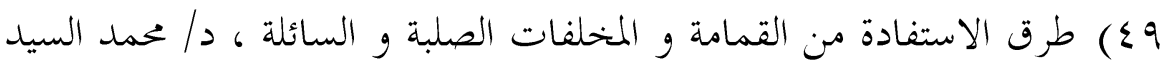

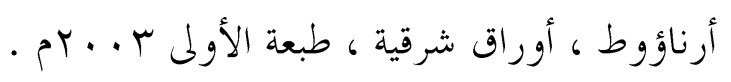

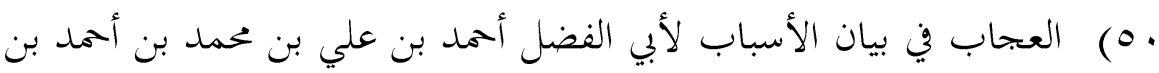

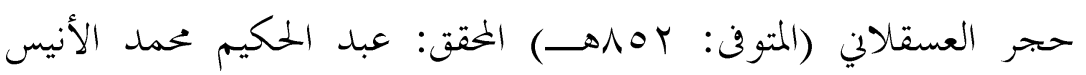

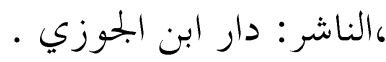

(0) عمدة القاري شرح صحيح البخاري للعيني ، الناشر: دار إحياء التراث العربي - بيروت

1479 
ror) عمليات نقل و تأجير الأعضاء البشرية ، دراسة مقارنة بين الشريعة و

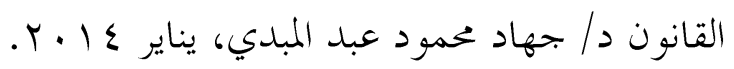

به) غرائب القرآن ورغائب الفرقان ، المؤلف: نظام الدين الحسن بن محمد بن

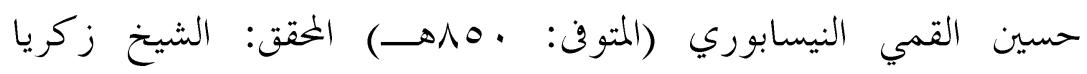

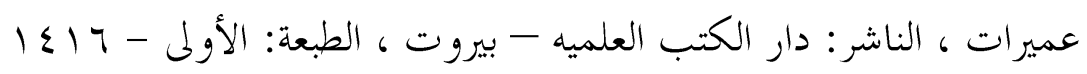

ع) الغريبين في القرآن والحديث لأبي عبيد أحمد بن محمد الهروي (المتوفى

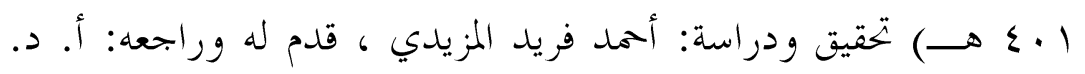

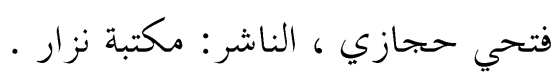

00) الغريبين في القرآن والحديث لأبي عبيد أحمد بن محمد الهروي (المتوفى ا ـــ

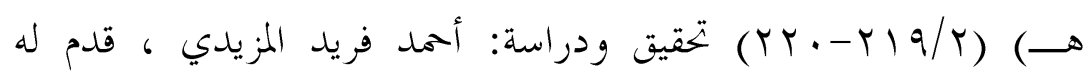

وراجعه: أ. د. فتحي حجازي ،الناشر: مكتبة نزار مصطفى الباز -

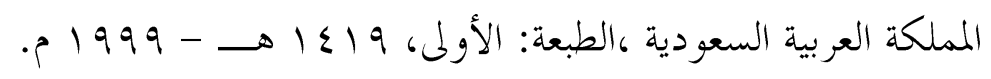
به ) فتح الباري شرح صحيح البخاري لابن حجر العسقلالي ، الناشر: دار

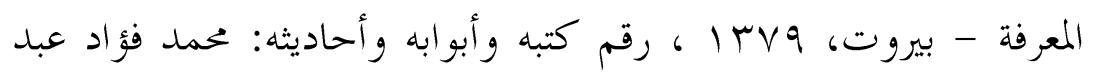
الباقي ، قام بإخراجه وصححه وأشرف على طبعه: محب الدين الخطيب

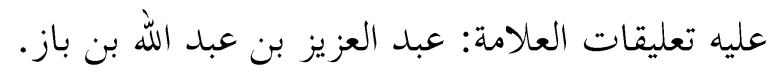

فو الح الرمن في تفسير القرآن لمحير الدين بن حمد العليمي المقدسي الحنبلي

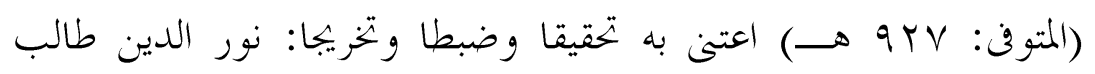

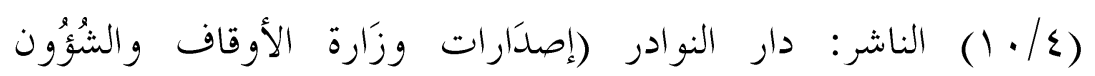

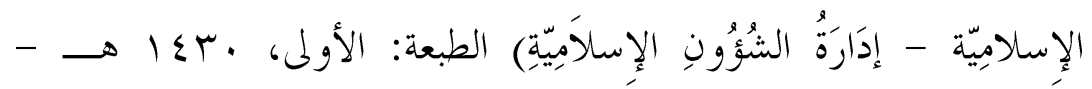

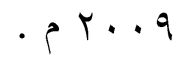


O1 فتوى الشيخ عطية صقر عام V991 ام ، راجع الأسرة تحت رعاية الإسلام - الجزء الأول ، و فتاوى الأزهر البخلد العاشر.

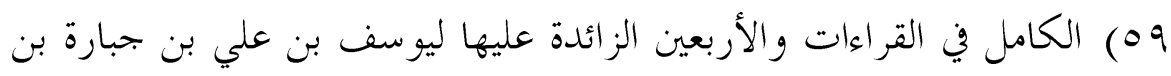

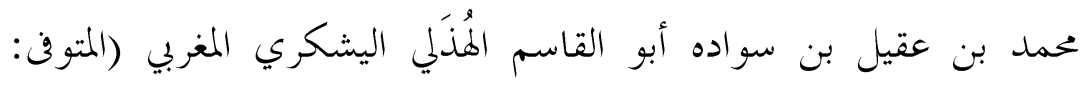

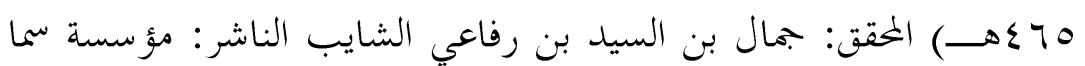

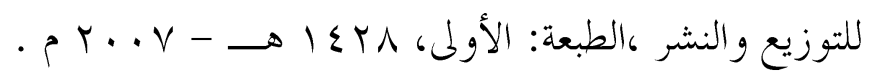

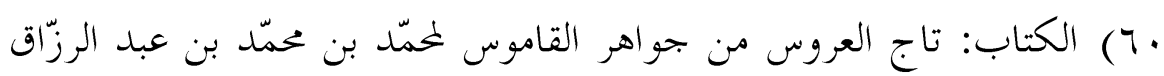

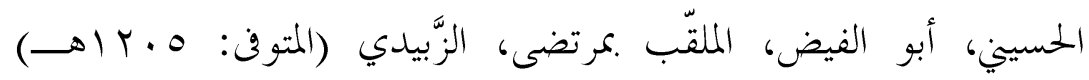

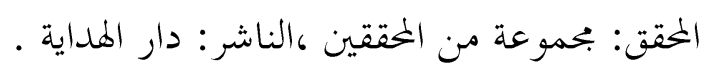

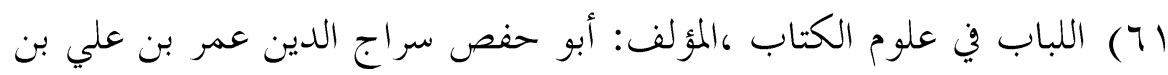

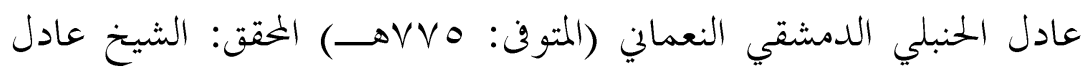

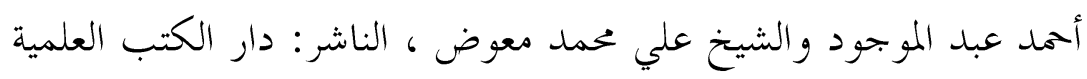

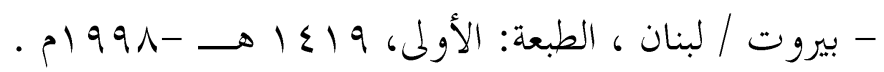

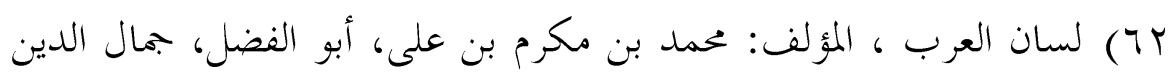

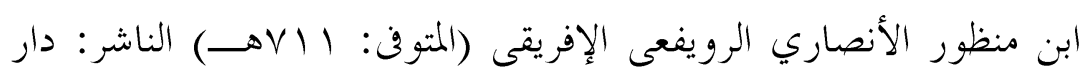

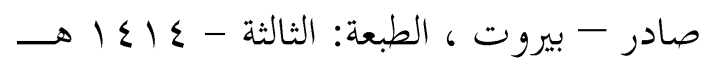

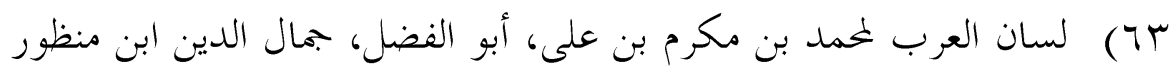

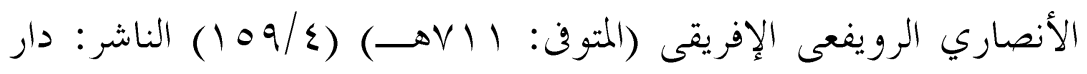

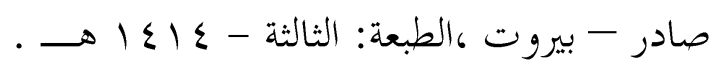

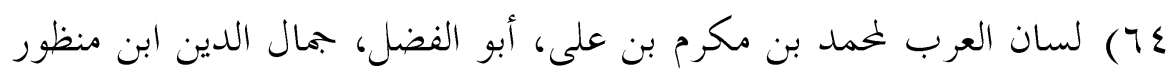

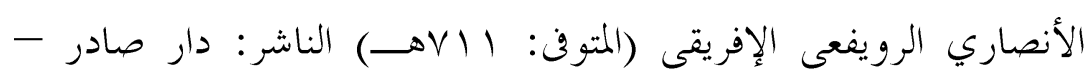

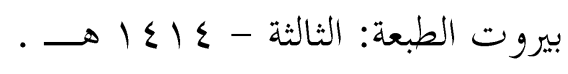


70) الماعز و الغنام تربية و إنتاج د/ مصطفى محمد عاشور ، مكتبة الجلاء ،

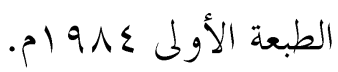

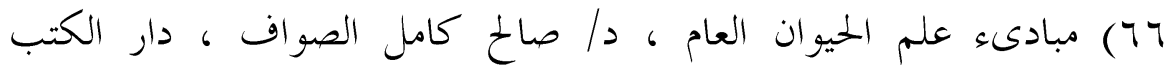

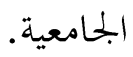

TV الخبتى من السنن المعروف بالسنن الصغرى للنسائي ، المؤلف: أبو عبد

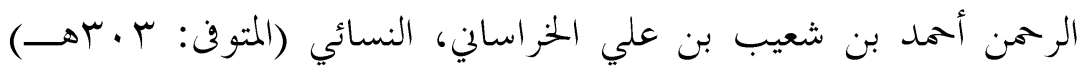

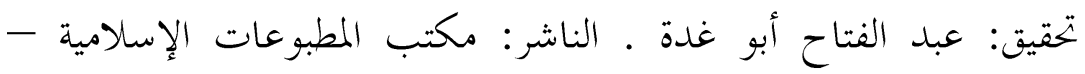

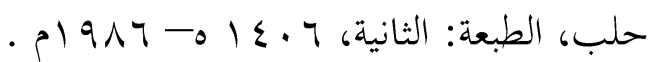

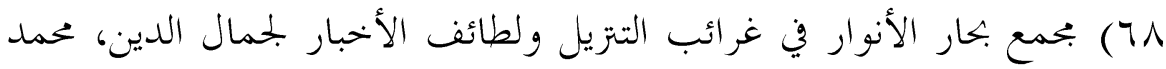

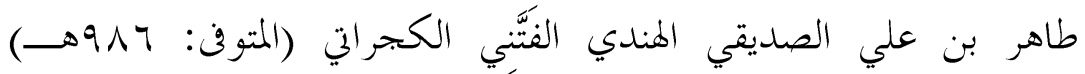

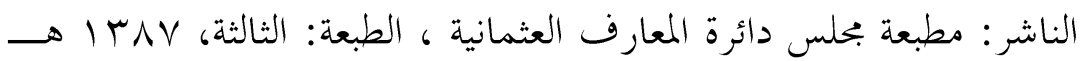
. $97 \mathrm{VV}-$ 79) الختسب في تبيين وجوه شواذ القراءات والإيضاح عنها لأبي الفتح عثمان

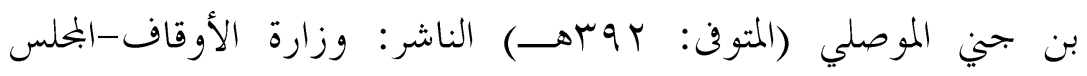

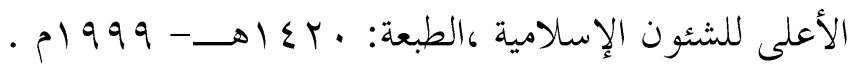

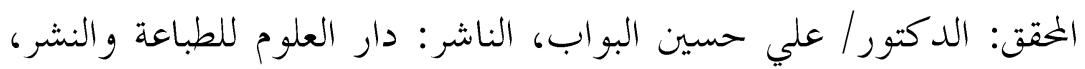

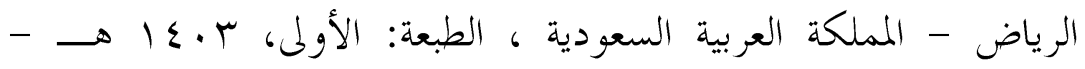
م 19人r الخقق: محمد فؤاد عبد الباقي ، الناشر: دار إحياء التراث العربي - بيروت . (V.

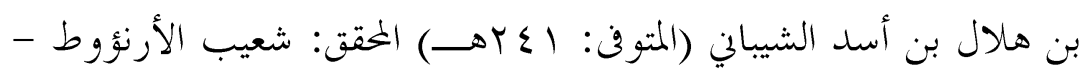

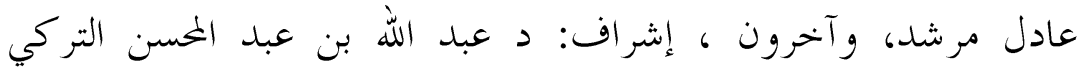

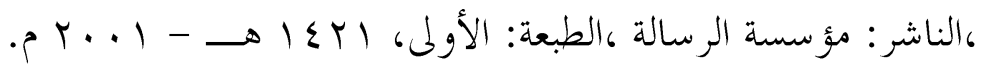




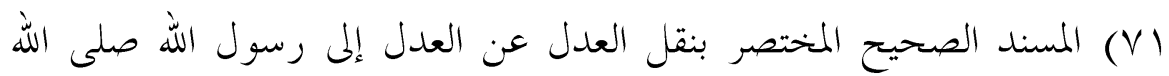

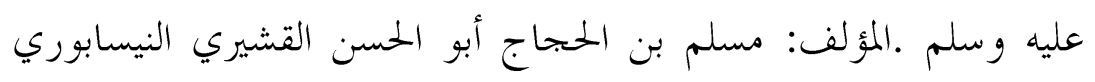

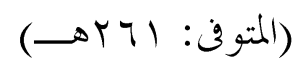

(VY

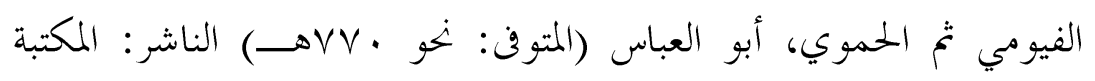

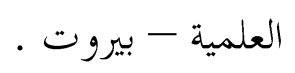

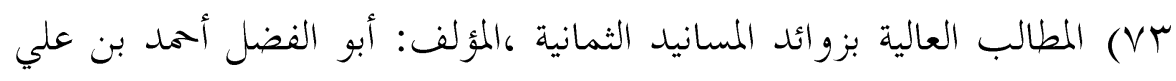

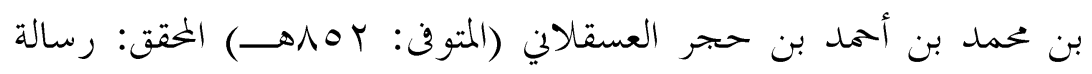

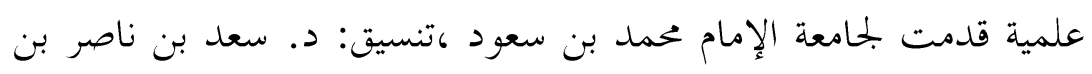
عبد العزيز الشثري ،الناشر: دار العاصمة، دار الغيث - السعودية ،الطبعة:

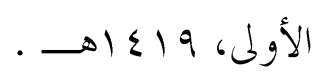

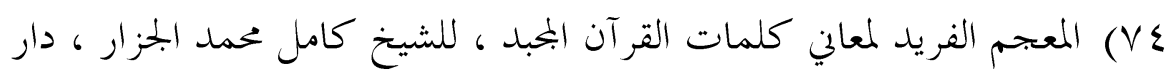

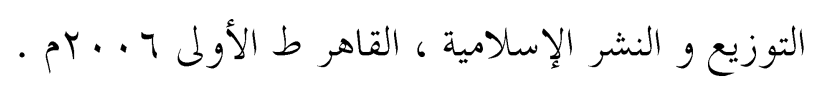

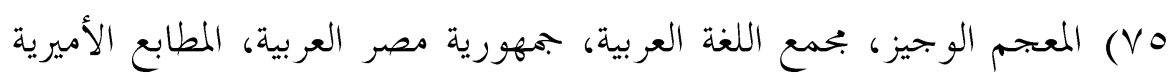

$$
\text { . } 96
$$

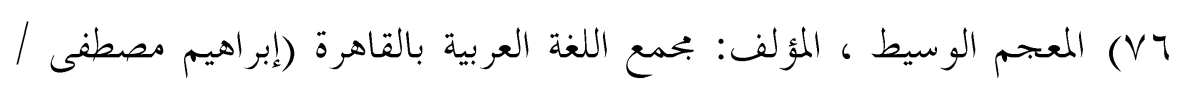

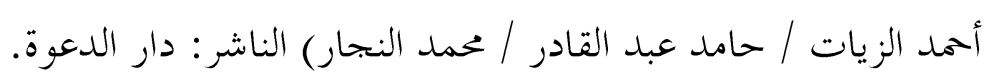

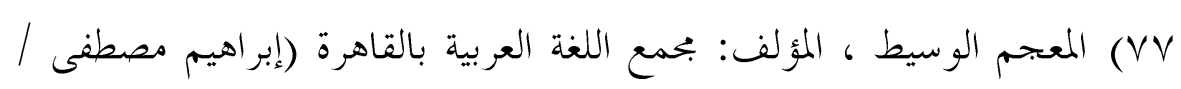

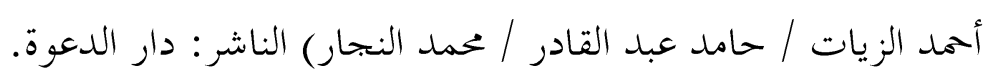

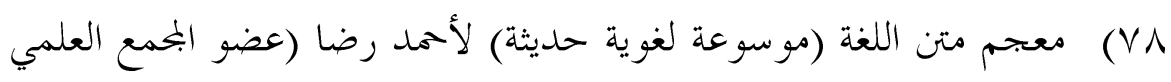

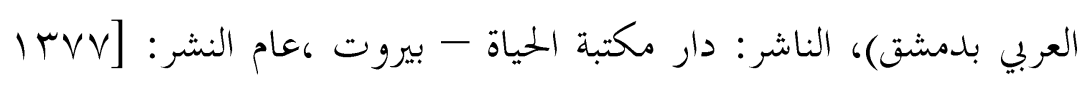

$$
[\rightarrow 1 \% \text {. - - }
$$


V9 معجم متن اللغة (موسوعة لغوية حديثة) لأحمد رضا (عضو البحمع العلمي

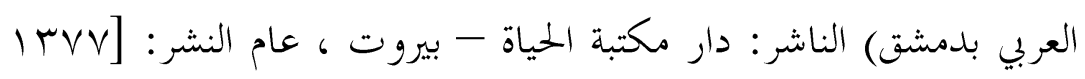

$$
\text { [- } 1 \text { 1 r 1 . - }
$$

• م) مفاتيح الغيب أو التفسير الكبير المؤلف: أبو عبد الله محمد بن عمر بن

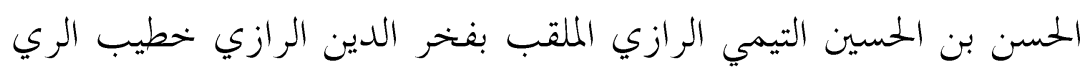

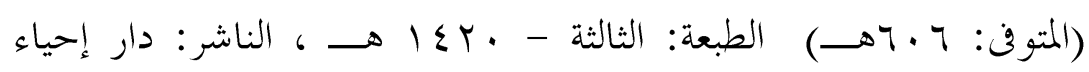

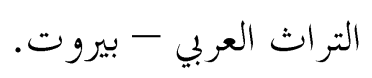

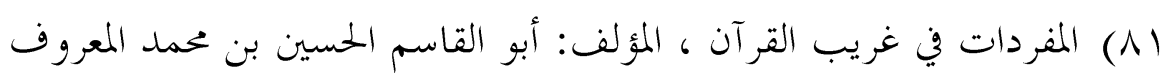

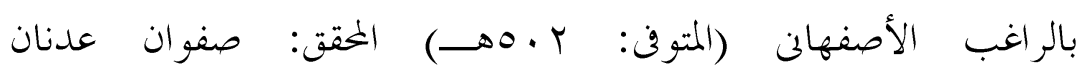

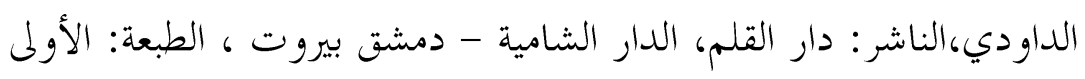

$$
\rightarrow 1 \leqslant 1 Y-
$$

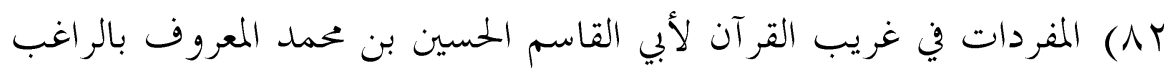

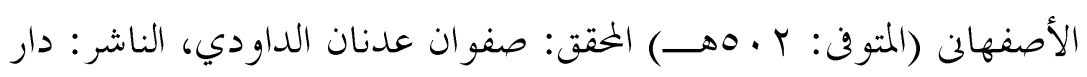

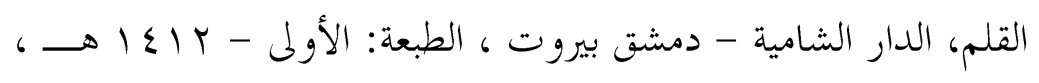

r امثنهل الحديث في شرح الحديث للأستاذ الدكتور موسى شاهين لاشين ،

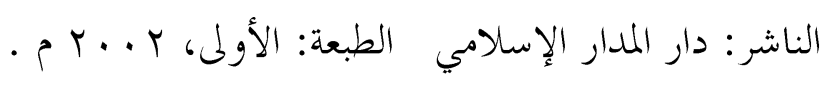
ع) المهندس الصغير في السيارات و العربات و السكك الحديدية د/ محمد عاطف البرقوقي، مطبعة المعارف ، مصر.

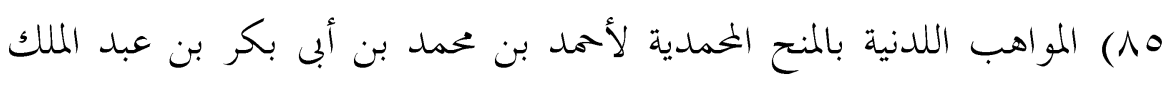

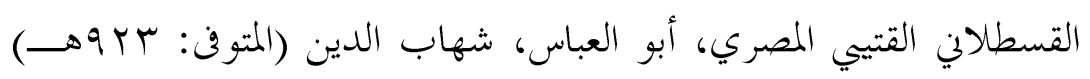

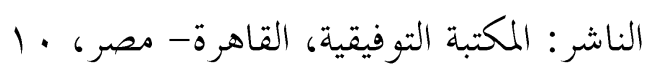


بم) الموسوعة الكونية الكبرى ، د/ماهر أحمد الصوفي ، المكتبة العصرية ،

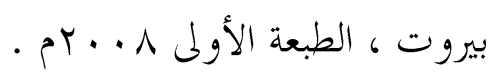

(AV

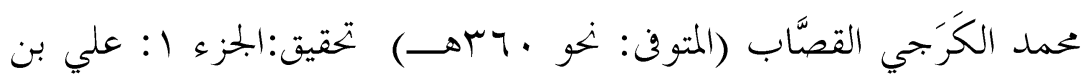
غازي التويجري ،الجزء r - r: إبراهيم بن منصور الجنيدل ، الجزء ؟ع:

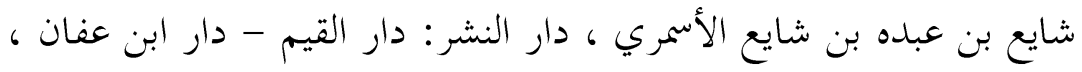

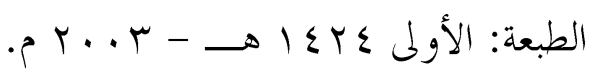

^ᄉ النهاية في غريب الحديث والأثر بحد الدين أبو السعادات المبارك بن محمد بن محمد بن محمد ابن عبد الكريم الشيباني الجزري ابن الأثير (المتوفن:

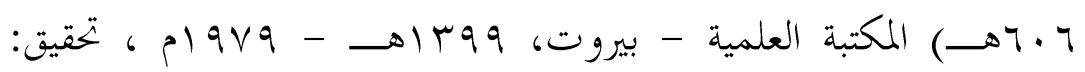
طاهر أحمد الزاوى - محمود محمد الطناحي . 
